UNIVERSIDADE DE SÃO PAULO

ESCOLA DE ENFERMAGEM

KÁTIA POLES

O DESENVOLVIMENTO DO CONCEITO DE MORTE DIGNA NA UTI PEDIÁTRICA

SÃO PAULO

2008 


\section{KÁTIA POLES}

\section{O DESENVOLVIMENTO DO CONCEITO DE MORTE DIGNA NA UTI PEDIÁTRICA}

Tese apresentada à Escola de Enfermagem da Universidade de São Paulo para obtenção do título de Doutor em Enfermagem.

Orientadora: Prof ${ }^{a}$. Dr ${ }^{a}$. Regina Szylit Bousso

Financiamento:

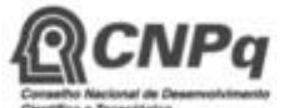


AUTORIZO A REPRODUÇÃO TOTAL OU PARCIAL DESTE TRABAHO, POR QUALQUER MEIO CONVENCIONAL OU ELETRÔNICO, PARA FINS DE ESTUDO E PESQUISA, DESDE QUE CITADA A FONTE.

Assinatura: Data

Catalogação na Publicação (CIP)

Biblioteca "Wanda de Aguiar Horta"

Escola de Enfermagem da Universidade de São Paulo

Poles, Kátia.

O desenvolvimento do conceito de morte digna na UTI pediátrica. / Kátia Poles. - São Paulo, 2008. $133 \mathrm{p}$.

Tese (Doutorado) - Escola de Enfermagem da Universidade de São Paulo.

Orientadora: Profa ${ }^{\mathrm{a}}{ }^{\mathrm{a}}$ Regina Szylit Bousso.

1. Cuidado da criança 2. Unidades de terapia intensiva 3. Atitudes frente à morte 4. Formação de conceito 5 .

Cuidados a doentes terminais. I. Título. 
Poles K. Concept development of the dignified death in the pediatric ICU. [thesis] São Paulo (SP), Brasil: Escola de Enfermagem, Universidade de São Paulo; 2008.

\begin{abstract}
The purpose of this research was to develop the concept of dignified death for children in the Pediatric Intensive Care Unit. The Hybrid Model of Concept Development was applied in its three phases: Theoretical, Fieldwork and Final Analytical. In the Theoretical Phase 49 papers in the Medical and Nursing fields were analyzed, which studied and focused on the dignified death for children. The Fieldwork was conducted through semi-structured interviews with nine doctors and seven registered nurses who worked in pediatric ICUs. The data from the Fieldwork Phase was analyzed having the results of Theoretical Phase as the theoretical axis and the Content Analysis as the methodology. In the Final Analytical Phase, the results from the Theoretical and Fieldwork Phases and were compared, analyzed and integrated. The data show that the DIGNIFIED DEATH for children in the pediatric ICU means having a clinical treatment of excellence at the end-of-life, honoring the benefits of the natural evolution of the disease, respecting the socio-cultural aspects, physical comfort and welfare. A dignified death occurs in a context of veracity and partnership between the team and the family, in which it is possible to express hopes and fears. The result of the dignified death is the relief of suffering from both the child and the family. Data from the Theoretical Phase suggests that the antecedents, attributes and consequences of dignified death as being protocol situations, however, in the Fieldwork it was possible to identify the component of the experience behind the conduct of the professionals when dealing with children at end-of-life. Thus, it was possible to understand how the manifestation of the concept occurs in clinical practice, allowing the expansion of the data identified in the Theoretical Phase. Clarifying the concept of dignified death in the pediatric ICU can strengthen theories about end-of-life care to children and families and makes it possible to professionals who work in clinical practice to reflect on the motivations that guide their attitudes and decisions when dealing with a child in life-sustaining condition.
\end{abstract}

KEYWORDS: Pediatric Intensive Care Units. Attitude to Death. Life Support Care. Concept Formation. 
Nome: Kátia Poles

Título: O desenvolvimento do conceito de morte digna na UTI pediátrica

Tese apresentada à Escola de Enfermagem da Universidade de São Paulo para obtenção do título de Doutor em Enfermagem.

Aprovada em:

\section{Banca Examinadora}

Prof. Dr. Instituição:

Julgamento: Assinatura:

Prof. Dr. Instituição:

Julgamento: Assinatura:

Prof. Dr. Instituição:

Julgamento: Assinatura:

Prof. Dr. Instituição:

Julgamento: Assinatura: 


\section{DEDICATÓRIA}

\section{Dedico este trabalho com todo o meu amor:}

À minha mãe Amália (in memoriam), que, sem saber, colocou-me diante do mais doloroso desafio: comprometer-me com o estudo da morte. Seu amor conduziu-me pelo caminho e me fez chegar até aqui.

Ao meu pai Alceu (in memoriam), com quem aprendi o significado dos valores éticos e morais. Seu exemplo de caráter e dignidade permanecerá comigo por toda a minha vida.

Meus queridos Pais, vocês ajudaram-me a compreender tanto o sentido da vida como o da morte.

Ao meu marido Cristiano, por me presentear com seu amor incondicional. Você não apenas encorajou e possibilitou a produção desta tese, como também ajudou a expandir meu pensamento através de nossas inúmeras conversas sobre a morte. Você é co-autor desta e das histórias de amor mais significativas da minha vida. 


\section{AGRADECIMENTO ESPECIAL}

À Profa. Dra. Regina Szylit Bousso, minha querida amiga e orientadora, pela atenção, competência, carinho e, sobretudo, por todos os ensinamentos pessoais que vão muito além destas páginas. Sou-lhe profundamente grata pelas lições acadêmicas e de vida que pude aprender. 


\section{AGRADECIMENTOS}

À minha família de Tatuí: Júnior, Luciana, Amanda e André, meu esteio e fonte constante de inspiração. Vocês são um presente de Deus em minha vida.

À minha família de Lavras: Antônio, Maria Nilda, Larissa, Gustavo, Fabrício, Vássia e Lara, pelo apoio, torcida e, principalmente, por me acolherem tão carinhosamente.

Ao Prof. Dr. Leo Pessini e à Profa. Dra. Margareth Angelo, pelas valiosas contribuições em meu Exame de Qualificação.

À Profa. Dra. Cristina Maria Garcia de Lima Parada, pelo exemplo de competência e disciplina. A você devo a abertura do meu caminho na pesquisa e a possibilidade de vislumbrar novos horizontes.

À Secretaria de Pós-Graduação da Escola de Enfermagem da Universidade de São Paulo, em especial, à Silvana, Dayse e Tieko, pela generosidade e atenção ao longo de todos estes anos.

À minha querida amiga Naná, pelo convívio prazeroso e exemplo de competência. Sua amizade foi um grande presente durante o Doutorado.

À Andréia, retaguarda carinhosa, pela ajuda que permitiu que a vida em casa pudesse seguir o seu curso, independente da minha presença.

À Geralda, amiga e terapeuta, pela escuta compreensiva, que me permitiu significar e ressignificar minhas experiências de perda.

À Maira, pela generosidade e prontidão para me ajudar nos momentos difíceis de finalização da tese. 
À Janice Yunes, pela disponibilidade e competência na revisão e editoração do trabalho.

Ao Centro Universitário de Lavras - UNILAVRAS, em especial à Profa. Christiane Lunkes Argenta, por acreditar no meu trabalho e conceder o afastamento de minhas atividades docentes para a realização desta tese.

Aos meus Alunos de ontem, de hoje e de sempre, por serem a minha constante motivação na busca pelo saber.

Às Instituições Participantes, por me abrirem as portas para a execução da pesquisa.

Aos Médicos e Enfermeiras que participaram da pesquisa, pela generosidade ao compartilharem comigo a sua experiência.

Ao Conselho Nacional de Desenvolvimento Científico e Tecnológico (CNPq), pelo apoio financeiro, que possibilitou infra-estrutura para a realização deste trabalho. 
Poles K. O desenvolvimento do conceito de morte digna na UTI pediátrica. [tese] São Paulo: Escola de Enfermagem, Universidade de São Paulo; 2008.

\section{RESUMO}

O objetivo deste estudo foi desenvolver o conceito de morte digna da criança na Unidade de Terapia Intensiva pediátrica. O Modelo Híbrido de Desenvolvimento de Conceitos foi aplicado em suas três fases: Teórica, de Campo e Analítica Final. $\mathrm{Na}$ Fase Teórica, foram analisados 49 artigos nas áreas Médica e de Enfermagem que estudaram e focalizaram a morte digna da criança. A Fase de Campo foi conduzida através de entrevistas semi-estruturadas com nove enfermeiras e sete médicos que atuavam em UTI pediátrica. Os dados da Fase de Campo foram analisados utilizando-se os resultados da Fase Teórica como eixo teórico e a Análise de Conteúdo como referencial metodológico. Na Fase Analítica Final, os resultados da Fase Teórica e de Campo foram comparados, analisados e integrados. Os dados evidenciam que a MORTE DIGNA na UTI pediátrica é ter um tratamento clínico de excelência no final de vida, com honra aos benefícios da evolução natural da doença, respeito aos aspectos socioculturais, conforto físico e bem-estar. A morte digna ocorre em um contexto de veracidade e parceria entre a equipe e a família, no qual é possível expressar expectativas e receios. O resultado da morte digna é o alívio do sofrimento tanto da criança quanto da família. Os dados da Fase Teórica apontam os antecedentes, atributos e conseqüências da morte digna como situações protocolares, porém, na Fase de Campo foi possível identificar o componente experiencial que está por trás das condutas dos profissionais diante da criança em final de vida. Assim, pôde-se compreender como se dá a manifestação do conceito na prática clínica, possibilitando a ampliação dos dados identificados na Fase Teórica. Clarificar o conceito de morte digna na UTI pediátrica permite fortalecer teorias sobre os cuidados no final de vida à criança e à família, bem como possibilita aos profissionais que atuam na prática clínica refletirem sobre as motivações que pautam atitudes e decisões diante da criança fora de possibilidade de cura.

PALAVRAS-CHAVE: Unidades de Terapia Intensiva Pediátrica. Atitude Frente à Morte. Cuidados para Prolongar a Vida. Formação de Conceito. 


\section{LISTA DE ILUSTRAÇÕES}

Figura 1 - Componentes do Modelo Híbrido de Desenvolvimento de Conceitos 028

Figura 2 - Relação entre antecedentes, atributos e conseqüências 032

Gráfico 1 - Distribuição dos artigos por período de publicação 034

Gráfico 2 - Idioma dos artigos $\quad 035$

Gráfico 3 - País de origem do artigo 035

Gráfico 4 - Metodologias utilizadas 036

Gráfico 5 - $\quad$ Autores mais freqüentes 036

$\begin{array}{ll}\text { Gráfico } 6 \text { - Especialidade dos autores } & 037\end{array}$

$\begin{array}{lll}\text { Gráfico } 7 \text { - } & \text { Área em que o artigo foi desenvolvido } & 037\end{array}$

$\begin{array}{lll}\text { Quadro } 1 \text { - Organização dos artigos } & 038\end{array}$ 


\section{LISTA DE TABELAS}

$\begin{array}{lll}\text { Tabela } 1 \text { - } & 055\end{array}$

Tabela 2 - Caracterização dos entrevistados 057 


\section{SUMÁRIO}

1 INTRODUÇÃO

1.1 CONTEXTUALIZANDO A PESQUISA ……………................................... 014

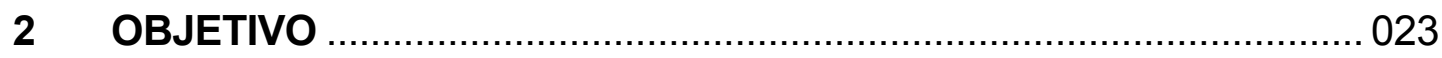

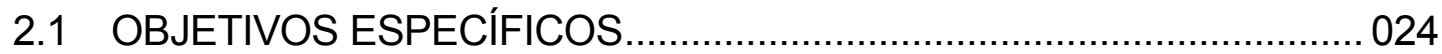

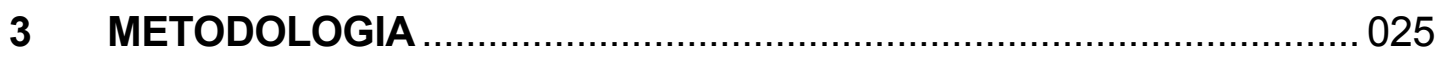

3.1 SOBRE O DESENVOLVIMENTO DE CONCEITO …................................ 026

3.2 MODELO HÍBRIDO DE DESENVOLVIMENTO DE CONCEITOS ......... 028

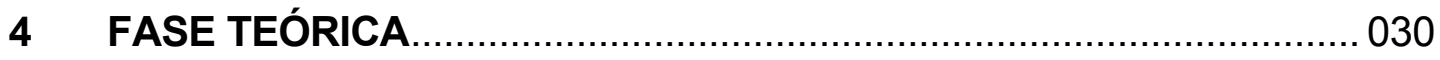

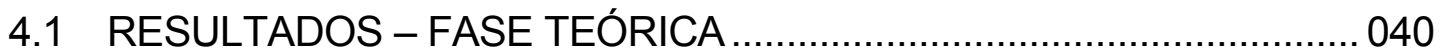

4.2 DIAGRAMA DOS RESULTADOS - FASE TEÓRICA ……................... 049

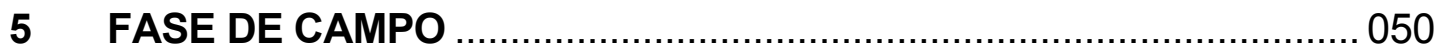

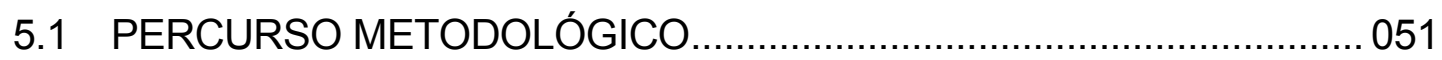

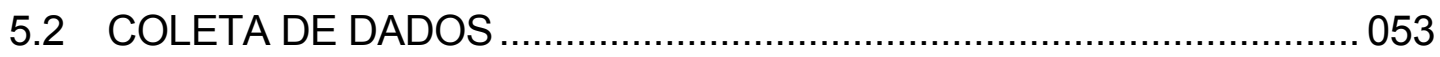

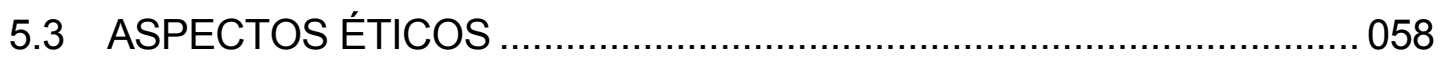

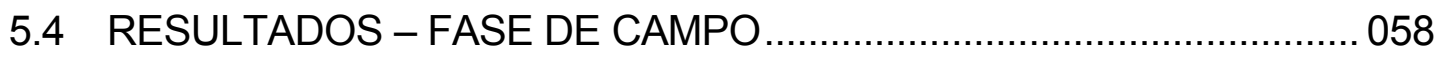

5.5 DIAGRAMA DOS RESULTADOS - FASE DE CAMPO ......................... 083

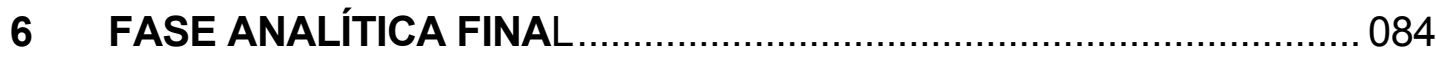

6.1 DEFININDO A MORTE DIGNA NA UTI PEDIÁTRICA ......................... 099

6.2 DIAGRAMA DOS RESULTADOS - FASE ANALÍTICA FINAL ............. 103

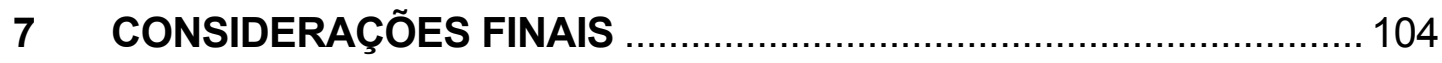

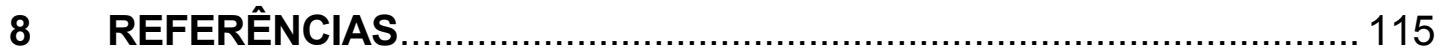

9 APÊNDICE

10 ANEXO 


\section{INTRODUÇÃO}

“Não, não, a morte não é algo que nos espera no fim. É companheira silenciosa que fala com voz branda, sem querer nos aterrorizar, dizendo sempre a verdade e nos convidando à sabedoria de viver." 
Minha opção por trabalhar com crianças aconteceu ainda durante a graduação; sentia-me motivada pela possibilidade de restabelecimento da saúde que elas apresentam, além da identificação com crianças e suas particularidades. Trabalhar com crianças, naquela época, era para mim sinônimo de vida e alegria.

Assim que me formei, passei por uma das mais difíceis e desafiadoras experiências da minha vida: a morte da minha mãe. Neste momento, passei para o outro lado - não estava mais na posição de profissional/enfermeira, e sim na de um familiar vivenciando a perda de uma pessoa querida. Esta experiência fez com que eu me tornasse mais sensível às situações de morte, que, até então, não eram motivo de inquietação.

Ao associar o meu desejo e afinidade por trabalhar com crianças com a temática morte, passei a direcionar os meus estudos para questões relativas à morte e aos cuidados no final de vida de crianças internadas em UTI pediátrica, local em que atuei vários anos como enfermeira assistencial.

Desta forma, utilizando o Interacionismo Interpretativo para a análise das narrativas biográficas de enfermeiras que atuam em UTI pediátrica, estudamos sua experiência ao compartilhar o processo de morrer com a família (Poles, Bousso; 2004, 2006). O trabalho evidenciou os fatores que contribuem para o afastamento e/ou aproximação da enfermeira à família nesse contexto.

Desenvolver esta pesquisa e atuar como enfermeira assistencial em UTI pediátrica permitiram-me vislumbrar possibilidades para a melhoria dos cuidados à criança e à família no final de vida. Porém, vários questionamentos quanto à morte de crianças nesse contexto permaneciam sem respostas, tais como: $O$ que é a morte digna da criança na UTI pediátrica? O que é preciso para que a morte digna aconteça na UTI pediátrica? Quais ações/situações são necessárias para proporcionar a morte digna para a criança na UTI pediátrica? O que se espera ao proporcionar a morte digna para a criança? 
Assim, dando continuidade a esta linha de pesquisa sobre os cuidados no final de vida na Unidade de Terapia Intensiva pediátrica (UTIp), o presente estudo pretende ampliar e aprofundar o conhecimento sobre o conceito de morte digna da criança na UTI pediátrica.

\subsection{CONTEXTUALIZANDO A PESQUISA}

A idéia de morte digna que prevaleceu na cultura ocidental na era prémoderna estava fortemente relacionada ao componente religioso. Morrer dignamente era morrer em paz com Deus e próximo da família e das pessoas do convívio social. Nesse contexto, os cuidados médicos eram considerados secundários.

O surgimento da ciência médica na segunda metade do século XVIII provocou uma transformação na maneira como a morte era vista pela sociedade. Esse fato se deve principalmente porque as causas de morte mais comuns podiam ser evitadas. A morte tornou-se algo a ser prevenido e sua ocorrência, eventualmente, era considerada uma falha. Nessa época, o ideal de morte digna está relacionado a três frases (Walters, 2004):

- A morte que não acontece ainda: a morte é projetada em um futuro inimaginável;

- A morte que não se vê acontecer: é a morte progressivamente removida das casas e da comunidade para as instituições de saúde;

- A morte que acontece sem que ninguém perceba: espera-se morrer de forma súbita e imperceptível.

Certamente, as atitudes da modernidade ainda existem na atualidade. É difícil perceber, no início do século XXI, que alguma coisa tenha sido radicalmente mudada. Na pós-modernidade, surge a idéia do controle do morrer, devido à influência dos cuidados paliativos no campo da medicina. A morte novamente torna-se um assunto que pode ser abertamente falado. 
Porém, a modernidade não pode ser ignorada, somente transcendida. A morte deve ser aceita como parte da vida, mas não algo sobre o qual nada se pode fazer. A diferença chave na idéia de morte digna entre a era prémoderna e a pós-moderna é o elemento do controle que aparece na área da saúde. A pessoa que passa pelo processo de morrer torna-se participante ativo desse processo e das decisões de final de vida (Walters, 2004).

Os avanços da medicina aumentaram a sobrevivência de pacientes com doenças graves consideradas anteriormente irrecuperáveis. Entretanto, em muitos casos, levou ao prolongamento do processo de morrer às custas de sofrimento adicional para o paciente e seus familiares (Lago et al., 2005; Moritz, Nassar, 2004; Schramm, 2002).

Segundo Horta (1999), quando a vida física é considerada como bem supremo e absoluto, acima da liberdade e da dignidade, a sua manutenção, a todo o custo, transforma-se em idolatria. Muitas vezes, a medicina promove implicitamente esse culto idólatra à vida, organizando a fase final da doença como uma luta desmedida contra a morte.

Nos dias atuais, tanto a doença como a morte residem no hospital, deixando de ocupar, como outrora, o aconchego do lar. Há uma particularidade a ser destacada nesse ponto: a partir de meados do século passado, começam a surgir as modernas terapias intensivas; a partir daí, os objetivos primários do tratamento, através de sofisticados recursos terapêuticos, passaram a ser: qualificar, quantificar e controlar uma ampla variedade de fenômenos biológicos. Tais preocupações fazem esquecer que na outra extremidade dos tubos, cabos e drenos, atrás de alarmes e restrito ao leito, encontra-se um ser humano (Moritz, Nassar, 2004).

No universo da pediatria brasileira, as primeiras unidades de terapia intensiva foram inauguradas na década de 1970 (Souza et al., 2004). Atualmente, a maioria das crianças morre nos hospitais, principalmente nas Unidades de Terapia Intensiva pediátrica. Assim, dignificar e humanizar a etapa final da vida e a morte tornam-se um desafio para os profissionais de saúde que ali atuam. O intensivismo pediátrico é uma especialidade jovem e que desfrutou de incríveis avanços tecnológicos nos últimos anos, os quais 
criaram situações inimagináveis em que, freqüentemente, o limite do prolongamento da vida é contraposto em favor do prolongamento da morte (Rotta, 2005).

Os avanços das terapias de suporte têm possibilitado o manejo de várias falências orgânicas através da ventilação mecânica, filtração renal, drogas vasoativas e nutrição parenteral, entre outros. Além disso, outras modalidades de tratamento têm se expandido, como a cirurgia cardíaca, a neurocirurgia e o transplante de órgãos. Com isso, há um aumento da expectativa de vida e conseqüente diminuição da mortalidade de crianças que anteriormente eram consideradas irrecuperáveis. No entanto, o uso destes mesmos recursos pode levar à manutenção de uma condição de vida artificial (Torreão et al., 2004).

Hoje, um número crescente de mortes que ocorre nas Unidades de Terapia Intensiva (UTIs) é resultado da suspensão ou limitação de tratamentos considerados fúteis ou inúteis (Esteban et al., 2001; Ferrand et al., 2001; Keenan et al., 1997; Moritz et al., 2001), indicando a importância da comunicação efetiva entre paciente, familiares e equipe de saúde, para que seja possível alcançar uma decisão compartilhada. Por tratamento fútil ou inútil entende-se a ação médica cujos potenciais benefícios para o paciente são nulos ou improváveis, não superando os potenciais malefícios (Mota, 1999).

Muitas crianças morrem nas UTIs pediátricas como resultado de uma decisão de limitar ou suspender as medidas de suporte vital ou, ainda, não ressuscitar (Athabe et al., 2003; Burns et al., 2000; Carvalho et al., 2001; Garros et al., 2000, 2003; Kipper et al., 2005; Lago et al., 2005; Poles, Bousso, 2007; Tonelli et al., 2005; Torreão et al., 2000, 2004; Zawistowski, DeVita, 2004). Sabe-se que tal decisão está justificada na opção pela morte digna ou "boa morte". Esses aspectos refletem a ampla discussão iniciada na década de 1990 em torno dos dilemas éticos que envolvem o final da vida, questionando o paradigma da "vida a qualquer custo". Passou-se a valorizar o respeito pelo paciente, com a preocupação crescente quanto à manutenção da dignidade no final da vida (Garros, 2003; Kipper et al., 2000). 
A determinação da irreversibilidade em uma UTI é uma condição de extrema dificuldade, já que implica estabelecer, com relativa segurança, que um paciente é irrecuperável. No caso das UTIs pediátricas, esta questão é muito mais difícil, considerando que as crianças têm grande capacidade de recuperação e, muitas vezes, a evolução das doenças na infância é surpreendente tanto no prognóstico quanto nas potenciais seqüelas (Casanueva Mateos et al., 2005).

Crianças com doenças graves e de mau prognóstico provocam intensos dilemas éticos nas equipes. É extremamente difícil estabelecer fronteiras entre o que é cuidar e aliviar o sofrimento, fornecendo conforto e morte digna e usar medidas invasivas e dolorosas decorrentes dos avanços tecnológicos, que só prolongam o sofrimento por algum tempo.

Para Pessini e Barchifontaine (1994), morrer em paz e com dignidade refere-se

[...] àquelas situações em que se toma a decisão de não continuar mantendo a vida, suprimindo determinadas terapias ou não aplicando-as a um enfermo em que não existem possibilidades de sobrevivência.

Embora, na prática, várias mortes nas UTIs pediátricas sejam decorrentes de não-reanimação cardiopulmonar, há uma discrepância entre os procedimentos de ressuscitação efetivamente realizados e os dados correspondentes registrados nos prontuários. Não reanimar pacientes fora de possibilidades terapêuticas de cura é conduta amparada eticamente. Porém, a limitação de suporte de vida, até há pouco, não tinha definição legal em nossa realidade, refletindo o medo do profissional de ser processado por omissão de socorro (Torreão et al., 2000).

O Código de Ética Médica Brasileiro (Brasil, 1988 - $§ 2^{\circ}$ do artigo 61) prevê que a devida assistência médica aos pacientes fora de possibilidades terapêuticas consiste em lhes fornecer os meios terapêuticos suficientes para evitar o sofrimento do processo de morrer. Para Pithan (2004), a obrigação médica, de ordens legal e moral, é agir em benefício dos 
pacientes e, em algumas situações, este benefício pode consistir em não intervir, deixando-os morrer em paz e dignamente.

A dignidade da morte que a autora se refere consiste no respeito pela autonomia da pessoa que está morrendo ou seu representante legal, que deve ter o direito de decidir por aceitar ou não determinada intervenção terapêutica, somado à garantia da assistência necessária para um morrer livre de sofrimento (Pithan, 2004).

Em 28 de novembro de 2006, foi publicada no Diário Oficial da União a Resolução $n^{\circ}$ 1.805/2006 do Conselho Federal de Medicina (Brasil, 2006), cuja ementa pontua:

Na fase terminal de enfermidades graves e incuráveis é permitido ao médico limitar ou suspender procedimentos e tratamentos que prolonguem a vida do doente, garantindo-lhe os cuidados necessários para aliviar os sintomas que levam ao sofrimento, na perspectiva de uma assistência integral, respeitada a vontade do paciente ou de seu representante legal.

Tal Resolução ressalta que cabe ao médico diagnosticar o doente como portador de enfermidade em fase terminal. A partir desses pressupostos, define que:

Art. $1^{\circ}$ É permitido ao médico limitar ou suspender procedimentos e tratamentos que prolonguem a vida do doente em fase terminal, de enfermidade grave e incurável, respeitada a vontade da pessoa ou de seu representante legal.

$\S 1^{\circ} \mathrm{O}$ médico tem a obrigação de esclarecer ao doente ou a seu representante legal as modalidades terapêuticas adequadas para cada situação;

$\S 2^{\circ}$ A decisão referida no caput deve ser fundamentada e registrada no prontuário;

$\S 3^{\circ}$ É assegurado ao doente ou ao seu representante legal o direito de solicitar uma segunda opinião médica.

Art. $2^{\circ} \mathrm{O}$ doente continuará a receber todos os cuidados necessários para aliviar os sintomas que levam ao sofrimento, assegurada a assistência integral, o conforto físico, psíquico, social e espiritual, inclusive assegurando-lhe o direito da alta hospitalar.

Entretanto, vários juízes apontam que esta Resolução é nula por tratar de tema manifestadamente ilegal, com efeitos discutíveis e limitados no campo da responsabilidade médica. A partir desse ponto de vista, os médicos e as demais pessoas que agirem em conformidade com a citada 
Resolução não estarão isentos das responsabilidades civil e criminal oriundas de seus atos (Junqueira, 2007).

Junqueira (2007) aponta grande dificuldade em aceitar, do ponto de vista legal, algum tipo de efeito de uma resolução claramente ilícita e nula. Mas, por outro lado, acredita que talvez seja possível que a Resolução tenha relativa eficácia quanto à responsabilidade ética do médico perante os conselhos regionais e federal. Contudo, a Resolução em nada modifica as responsabilidades civil e criminal do médico com relação à limitação terapêutica, ou seja, aqueles que a realizarem não serão penalizados pelo conselho profissional, mas sim processados civil e criminalmente.

Desta forma, a dissonância entre os aspectos éticos e legais vigente no contexto brasileiro suscita dúvidas e receios, especialmente de ordem legal, para a comunidade médica nas situações de final de vida.

No que diz respeito à criança, especificamente, a legislação vigente em nosso país quanto aos Direitos da Criança Hospitalizada prevê as seguintes condições (Brasil, 1995):

- Estar acompanhada por sua mãe, pai ou responsável durante o processo de sua hospitalização.

- Não sentir dor quando existirem meios para evitá-la.

- Ter conhecimento adequado sobre sua enfermidade, cuidados terapêuticos e diagnósticos, respeitando sua fase cognitiva.

- Participação ativa de seus pais ou responsáveis quanto ao seu diagnóstico, tratamento e prognóstico, recebendo informações sobre os procedimentos a que ela será submetida.

- Ter uma morte digna (grifo nosso), junto aos seus familiares, quando esgotados os recursos terapêuticos disponíveis.

Os dados apresentados sugerem diretrizes éticas para as decisões e condutas de final de vida no contexto brasileiro, porém, sem o amparo legal para as condutas que possam provocar a antecipação da morte, diferentemente do que ocorre nos países desenvolvidos. 
Embora muito já se tenha escrito sobre a morte com foco no indivíduo, este trabalho pretende explorar o conceito de morte digna como um fenômeno presente nas tomadas de decisões de final de vida da equipe assistencial. A busca por um significado sempre ocorre nas situações de doença e morte. $\mathrm{O}$ conhecimento dos significados atribuídos pela equipe às suas experiências permite definir conceitos, fortalecer teorias, aperfeiçoar métodos de pesquisa, ajudando os profissionais a intervirem efetivamente, respeitando as subjetividades das famílias diante das situações de perda, luto e tomada de decisão.

Até os anos 1960, os profissionais de saúde tinham uma conduta mais paternalista nas situações de final de vida. Os médicos tomavam as decisões quanto ao tratamento e comunicavam seus pacientes ou, em algumas situações, familiares bem próximos (Glaser, Strauss, 1968).

O desenvolvimento de estudos nesta temática deu-se a partir de um esforço ou da necessidade da prática clínica, em oferecer maior autonomia e garantir que o cuidado recebido pelo paciente estivesse de acordo com os seus desejos. Assim, talvez pela influência da bioética, os trabalhos mais atuais focalizam aspectos da determinação pessoal e a preservação da autonomia do indivíduo. Estes estudos relacionam-se notadamente às tomadas de decisão quanto ao suporte de vida, especialmente aqueles que se referem à ressuscitação cardiopulmonar e à ventilação mecânica. Com maior freqüência, foram estudadas as áreas do adulto e do idoso (Blatt, 1999; Ditto et al., 2001; Ouslander et al., 1989; Swigart et al., 1996; Tilden et al., 1995; Weissman, 2004).

A tomada de decisão dos pais quanto ao uso ou não do suporte de vida para seus filhos internados em UTI pediátrica é baseada em informações adquiridas durante o processo de internação, as quais podem advir de recursos internos ou externos. Os externos são informações adquiridas pela Internet, com a equipe de saúde, parentes e amigos. Os internos estão relacionados, sobretudo, às experiências anteriores com decisões de suporte de vida, percepções e observações. Conversar com a família sobre estes aspectos pode ajudar a equipe a compreender como a experiência está sendo vivenciada e, assim, auxiliá-la na tomada de decisão (Sharman et al., 2005). 
Promover reuniões com a família, assumindo o papel de mediador para que ela expresse suas crenças sobre as decisões no final da vida, pode aliviar o estresse durante o processo de tomada de decisão. Esta estratégia ajuda os membros a conhecerem as diferentes perspectivas dentro da unidade familiar e, ao mesmo tempo, auxiliam a decidir qual interesse será privilegiado quanto à decisão (Leichtentritt, Rettig, 2002).

O editorial do Pediatric Critical Care of Medicine de setembro de 2005 apresenta resultados de um estudo realizado com pais de crianças internadas em UTI pediátrica e que vivenciaram a experiência de ter de decidir pelo suporte de vida para os filhos. A autora corrobora que esta é uma realidade comum hoje nas UTIs e alerta para a importância do uso adequado de uma comunicação aberta, entre os profissionais e pais, ressaltando as vantagens de uma relação transparente, fazendo-se uso de termos acessíveis. Estas condutas simples demonstram respeito e trazem alívio para o processo de decisão (Levetown, 2005).

Estes dados são importantes para a argumentação da problemática do presente estudo quando a criança está internada na UTI pediátrica. Sem uma compreensão clara sobre o conceito de morte digna, pouco pode ser realizado para promover a dignidade do processo de morrer nesta perspectiva. Conhecer mais a respeito de como se dão os processos de decisão da equipe, como se sucedem as interações durante este processo, quais significados os médicos e as enfermeiras de UTI pediátrica atribuem ao termo morte digna pode fortalecer conceitos básicos utilizados em diferentes teorias no trabalho com crianças e famílias no final de vida.

Embora os pesquisadores venham se dedicando a compreender como se dá o cuidado à criança durante o processo de morrer na UTI pediátrica (Benica et al., 1992; Davies, Eng, 1993; Davies et al., 1996; Casanueva Mateos et al., 2005; Papadatou et al., 2001, 2002; Poles, Bousso, 2006; Rashotte et al., 1997), não há registro na literatura tanto nacional como internacional acerca do desenvolvimento do conceito de morte digna na UTI pediátrica. 
Além disso, Meyer et al. (2002) indicam que pouco se sabe sobre a qualidade da assistência às crianças fora de possibilidades terapêuticas de cura. Ainda que algumas similaridades no cuidado de crianças e adultos possam ser apontadas, variáveis níveis de desenvolvimento emocional e cognitivo, bem como a participação da família nas decisões limitam algumas comparações. 
"Nossas vitórias sobre a doença e a morte são sempre temporárias, mas nossas necessidades de apoio e cuidado diante delas são sempre permanentes." 
O presente estudo teve como objetivo geral desenvolver o conceito de morte digna da criança na Unidade de Terapia Intensiva pediátrica.

\subsection{OBJETIVOS ESPECÍFICOS}

Os objetivos específicos foram:

- Desenvolver a definição de morte digna da criança na UTI pediátrica.

- Identificar os antecedentes, atributos e conseqüências da morte digna da criança na UTI pediátrica. 


\section{METODOLOGIA}

"A verdadeira origem da descoberta consiste não em procurar novas paisagens, mas em ter novos olhos." 


\subsection{SOBRE O DESENVOLVIMENTO DE CONCEITO}

A enfermagem vem construindo seu arcabouço teórico em um processo dinâmico, que tende a nascer da prática e a ela se voltar, em um movimento de busca de níveis crescentes de qualidade e complexidade. Esse processo de construção de conhecimento, a partir de pesquisas, parece ter como uma de suas principais metas situar a enfermagem no cenário da ciência (Padilha et al., 2001).

Ao se considerar que a ciência é constituída pelo movimento do senso comum à consciência crítica dos conceitos que, em muitas situações, aparecem mal definidos ou inadequadamente empregados, o esclarecimento de determinado conceito poderá contribuir com a construção do corpo de conhecimentos da área. Desse modo, a falta de clareza de alguns conceitos resulta em uma ciência menos consistente do que o desejável. A análise e o desenvolvimento de conceitos estão intimamente relacionados à evolução e expansão de conhecimentos na enfermagem (Rodgers, Knafl, 2000; Vendramini et al., 2003; Zagonel, 1996). Como resultado da contínua reformulação e refinamento de conceitos, a enfermagem vai se alicerçando em bases sólidas de conhecimento. Portanto, um dos pontos importantes na enfermagem, assim como em outras disciplinas, é tratar de conceitos.

O método de desenvolvimento de conceito oferece um veículo para identificar o significado do conceito em suas dimensões lógica, cognitiva e emocional. Isto implica que o referido processo não é útil apenas na descoberta de definições e significados, mas também no esclarecimento do porquê de tais acepções serem desenvolvidas (Hutchfield, 1999).

A ênfase no desenvolvimento de conceitos em enfermagem tem aumentado na última década, pois os pesquisadores têm se proposto a elucidar problemas que anteriormente permaneciam no senso comum. Isto ocorre porque alguns conceitos, que podem até ser óbvios, incluem terminologia vaga, ambigüidade de definições e inconsistência entre as teorias (Rodgers, Knafl, 2000). 
Um conceito é uma idéia ou construção mental elaborada acerca de um fenômeno, sendo essencial no desenvolvimento de pesquisas, assim como na construção de teorias (Simpson, 2001). Os conceitos compreendem atributos abstratos da realidade e, conseqüentemente, representam mais do que palavras ou imagens mentais, pois estas não capturam a natureza complexa dos conceitos (Rodgers, 2000). Para Morse (1995), conceitos são representações cognitivas e abstratas da realidade perceptível, formados por experiências diretas ou indiretas.

Portanto, um conceito deve estar inserido em um contexto, de modo que o significado e aplicação sejam possíveis, podendo contribuir para o avanço do conhecimento em determinada área. De acordo com Hopkinson e Hallet (2002), a morte digna é um conceito dinâmico, porque ele muda de acordo com o contexto social em que aparece.

Quando o pesquisador se propõe a desenvolver um conceito, deve primeiro selecionar um problema conceitual e, a partir daí, identificar a natureza do problema a ser conduzido pela pesquisa. Em um nível prático, ele pode se referir a várias situações, dentre as quais podem-se citar (Rodgers, 2000):

- Terminologia confusa ou palavra ambivalente usada para caracterizar determinados eventos ou fenômenos.

- Problemas que definem conceitos importantes para o desenvolvimento da pesquisa, teoria ou prática.

- Potenciais conflitos entre os conceitos estabelecidos e a situação atual encontrada na prática clínica.

- Necessidade de conceitos novos ou mais efetivos para caracterizar experiências clínicas.

Segundo Rodgers e Knafl (2000), um aspecto importante na análise e desenvolvimento de um conceito refere-se à relevância da proposta no que tange à importância para a prática. No caso deste estudo, a relevância está posta diante da necessidade de se facilitar a promoção de um cuidado efetivo visando uma morte digna para a criança e sua família. 


\subsection{MODELO HÍBRIDO DE DESENVOLVIMENTO DE CONCEITOS}

O método para desenvolvimento de conceito que foi utilizado constitui o Modelo Híbrido de Desenvolvimento de Conceitos, proposto por SchwartzBarcott e Kim (2000). Este Modelo considera três fases no desenvolvimento de um conceito, são elas:

- Fase 1 - Teórica;

- Fase 2 - de Campo;

- Fase 3 - Analítica Final.

É importante notar que as fases do processo são interconectadas e não distintas, como apresentado no diagrama a seguir.

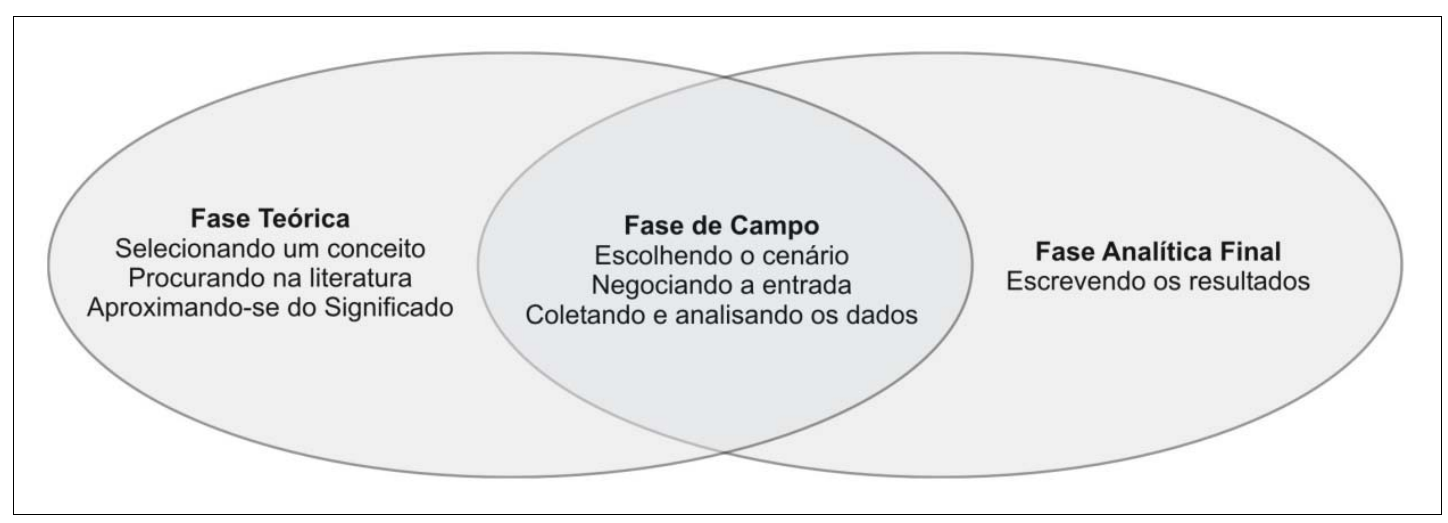

Figura 1 - Componentes do Modelo Híbrido de Desenvolvimento de Conceitos (Schwartz-Barcott, Kim, 2000)

Enquanto a análise de conceito usualmente tem sido considerada um trabalho teórico baseado na literatura, o Modelo Híbrido propõe um trabalho de análise teórica e trabalho de campo, favorecendo uma compreensão mais aprofundada do conceito (Öhlén, Segesten, 1998).

Na Fase 1 - Teórica, tenta-se esboçar uma definição do conceito através da busca na literatura, comparando e contrastando definições existentes. Na Fase 2 - de Campo, que sobrepõe a primeira, é enfatizado o componente empírico do processo, utilizando métodos qualitativos para coletar e analisar os dados. É importante destacar que a análise crítica da 
literatura inicia-se na Fase 1 e se estende até a 2, servindo, inclusive, como base para comparação com os dados coletados no campo de pesquisa. A Fase 3 - Analítica Final, inclui a interface entre a fase teórica e os dados provenientes do trabalho de campo e a redação dos resultados, isto é, a integração das duas fases anteriores (Schwartz-Barcott, Kim, 2000).

Ainda que didaticamente essas fases sejam divididas, no âmbito prático elas se inter-relacionam, especialmente a fase teórica e o trabalho de campo. Schwartz-Barcott e Kim (2000) argumentam que isso assegura que o conceito possa ser paulatinamente explorado em todas as suas dimensões. 
“... a verdade essencial da vida: ela é um sistema instável no qual se perde e se reconquista o equilíbrio a cada instante; a inércia é que é sinônimo de morte. A lei da vida é mudar." 
A análise crítica da literatura torna-se importante para demonstrar 0 rigor da pesquisa, reduzir os preconceitos do pesquisador, bem como clarificar a natureza do problema conceitual e ajudar o pesquisador a determinar o seu foco de estudo (Morse et al., 1996; Rodgers, Knafl, 2000; Schawartz-Barcott, Kim, 2000). Knafl e Deatrick (2000) ressaltam que todas as abordagens para o desenvolvimento de conceitos têm em comum a análise crítica da literatura como primeira etapa da pesquisa. Esta fase permite a identificação da "essência" do conceito, ou seja, os seus atributos, os quais representam a "real" definição do conceito (Rodgers, Knafl, 2000).

Uma avaliação crítica da literatura difere da revisão de literatura, onde o pesquisador detém-se a um tópico particular. $\mathrm{Na}$ análise crítica, o pesquisador critica ou desafia as idéias de outros autores, contribuindo para a pesquisa por explorar e desenvolver o conceito que será investigado (Morse, 2000).

Além disso, tal avaliação promove informações sobre as várias conceitualizações do conceito e em quais contextos ele foi utilizado por outros pesquisadores. Finalmente, promove informação sobre as suposições implícitas ou explícitas e a evolução da coerência do conceito. Essa análise resulta em novos insights, questões significativas e direções a serem tomadas na pesquisa (Morse, 2000).

Schwartz-Barcott e Kim (2000) afirmam que o desenvolvimento de conceito implica na exploração dos atributos, antecedentes e conseqüências. Quanto mais claro for o conceito, quer dizer, a expressão de seus "atributos essenciais", maior será a compreensão entre aqueles que o utilizam. Os atributos são as palavras e/ou expressões utilizadas, com freqüência, pelos autores para descrever as características do conceito (Rodgers, 1989).

Entende-se por antecedentes aquelas situações, eventos ou fenômenos que precedem o conceito de interesse. Os antecedentes auxiliam na compreensão do contexto social no qual o conceito é geralmente utilizado, bem como favorece o seu refinamento (Rodgers, 1989). 
As conseqüências do conceito dizem respeito a eventos ou situações resultantes da sua utilização (Rodgers, 1989). A definição precisa das conseqüências será concretizada após a exploração do conceito em sua manifestação prática.

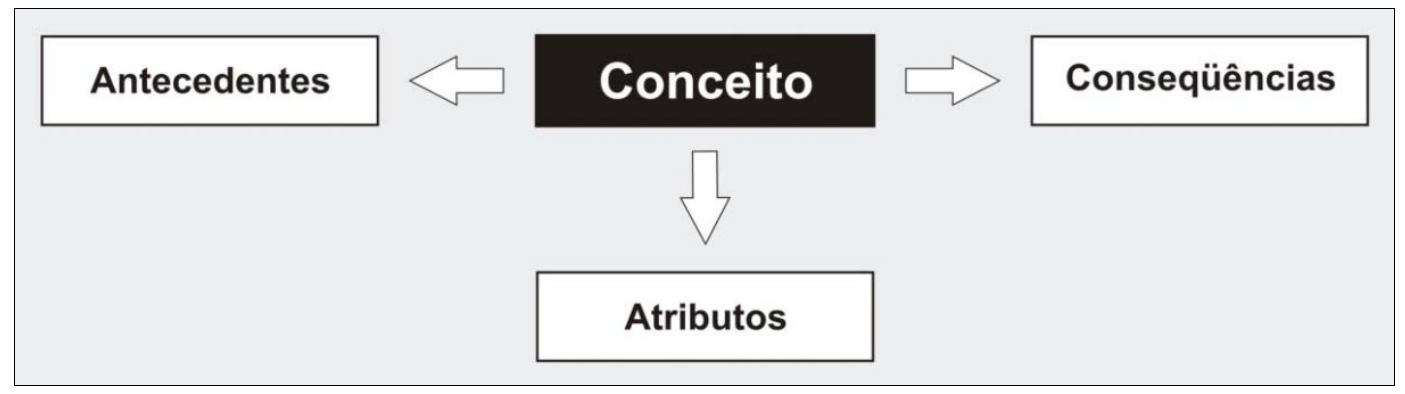

Figura 2 - Relação entre antecedentes, atributos e conseqüências

A seguir, será apresentado o desenvolvimento da Fase Teórica em todas as suas etapas.

No presente estudo, foram pesquisadas publicações nas áreas Médica e de Enfermagem, que estudaram e focalizaram a morte digna. A busca foi delimitada também pela língua, incluindo estudos em português, inglês e espanhol. Os critérios de exclusão foram: trabalhos que não apresentavam o resumo nas bases de dados, trabalhos fora da área de pediatria, uma vez que o foco da pesquisa é a morte digna da criança, e trabalhos de difícil acesso, como teses e dissertações.

O levantamento dos artigos foi realizado considerando-se as publicações entre os anos de 1990 a 2008. Este período foi selecionado considerando que o termo "morte digna" foi introduzido na literatura na década 1990 e não há registro, na área de pediatria, de publicações anteriores a este ano.

Vários autores registram 0 interesse crescente pelas questões relacionadas ao final de vida a partir dos anos 1990, com o surgimento de discussões acerca da manutenção da vida a qualquer custo e da bioética em um contexto de exponencial crescimento científico, onde o uso da tecnologia resulta em conflitos com os limites terapêuticos (Carvalho et al., 2001; Kipper et al., 2005; Torreão et al., 2004). 
Foram realizadas buscas nas seguintes bases de dados: Medline (Literatura Internacional em Ciências da Saúde), Lilacs (Literatura LatinoAmericana e do Caribe em Ciências de Saúde), Cinahl (Cummulative Index to Nursing and Allied Health Literature), Pubmed (National Library of Medicine and National Institutes of Health) e SciELO (Scientific Electronic Library Online). As opções de palavras-chave para acessar as publicações foram utilizadas nas seguintes combinações:

- Morte, digna, criança.

- Morte, dignidade, criança.

- Morte, boa, criança.

- Morrer, dignidade, criança.

- Morte, criança, unidade terapia intensiva.

Estas combinações de palavras-chave foram aplicadas em todas as bases de dados nos campos do título e resumo. À medida que eram feitas as buscas iniciais e lidos os artigos, foram identificados possíveis termos utilizados para descrever o conceito de morte digna, como é o caso da "boa morte", razão pela qual se expandiu a busca, utilizando também essa nomenclatura. A busca com a última combinação de palavras (morte, criança, unidade terapia intensiva) foi realizada com o intuito de averiguar os trabalhos que focalizavam o conceito no cenário específico do presente estudo.

Em cada uma destas buscas obteve-se um total de artigos e, a partir de então, iniciou-se a seleção dos artigos de interesse para sua leitura na íntegra. Para tanto, foram excluídos, primeiramente, os que não apresentavam relação com a temática do estudo pela leitura minuciosa dos títulos, por exemplo, aqueles que tratavam de questões fisiológicas, biológicas e celulares foram inicialmente retirados. Após essa primeira triagem, passou-se para uma outra etapa, que incluiu a leitura crítica dos resumos, onde também foram eliminados os artigos que se distanciavam da temática focalizada. Os trabalhos que suscitavam dúvidas quanto à sua relevância para o presente estudo foram lidos na íntegra, a fim se incluir ou não no rol de artigos eleitos para estudo em profundidade. 
Foram encontrados 49 trabalhos de interesse para leitura na íntegra. Fizemos a caracterização destes artigos, que foram nosso universo de estudo na Fase Teórica, quanto ao período e idioma de publicação, país em que o artigo foi desenvolvido, metodologias utilizadas, principais autores que se dedicaram a estudar a temática de interesse e sua área de atuação, bem como a área em que o artigo foi desenvolvido. Os dados são apresentados nos gráficos a seguir.

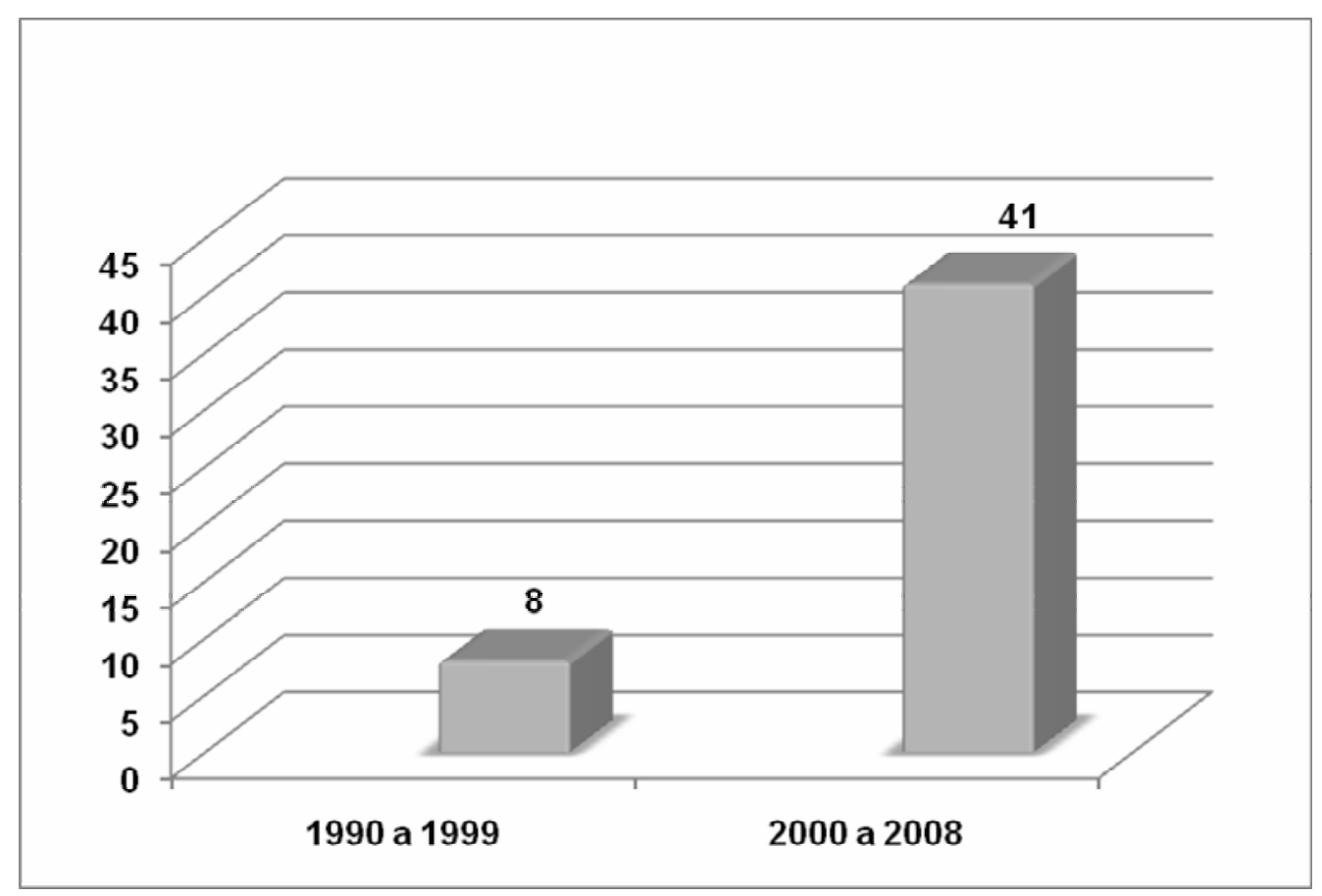

Gráfico 1 - Distribuição dos artigos por período de publicação

Observa-se um aumento significativo das publicações nos últimos oito anos, evidenciando um interesse crescente pelas questões relacionadas aos cuidados da criança no final da vida nesse período. 


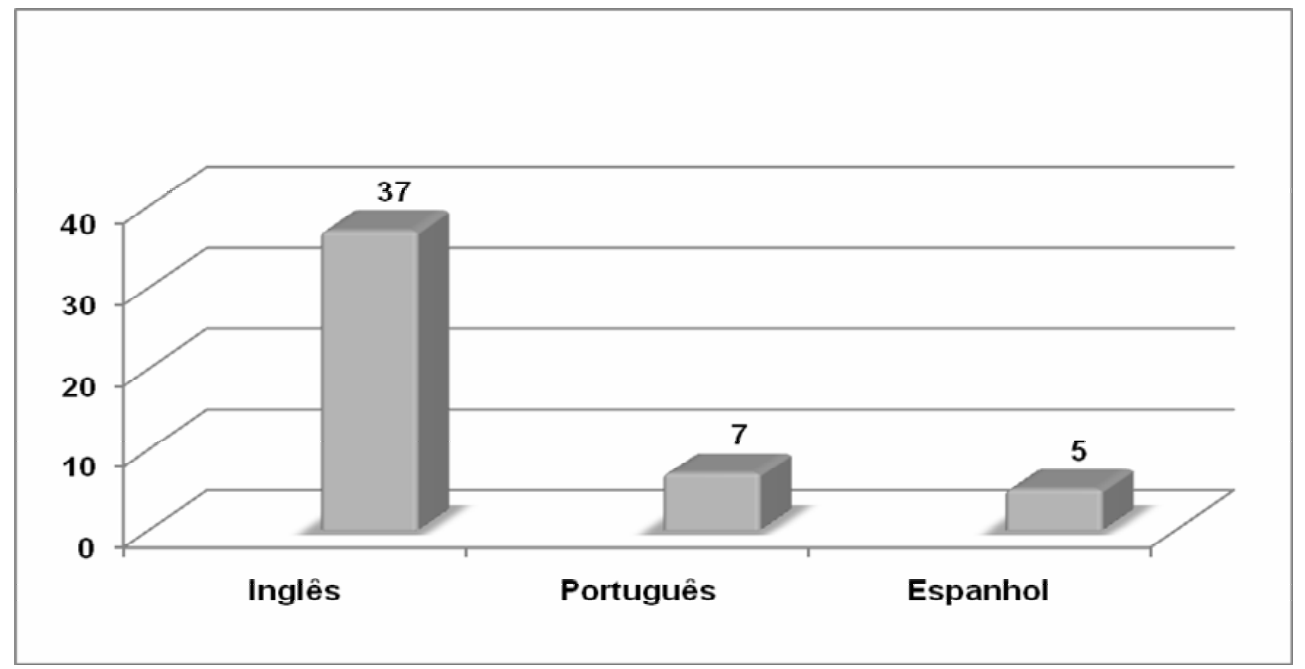

Gráfico 2 - Idioma dos artigos

Com relação ao idioma das publicações, nota-se a prevalência de artigos em língua inglesa, seguidos de outros em português e espanhol. Este dado evidencia que grande parte das publicações da área é desenvolvida ou publicada em países do hemisfério norte.

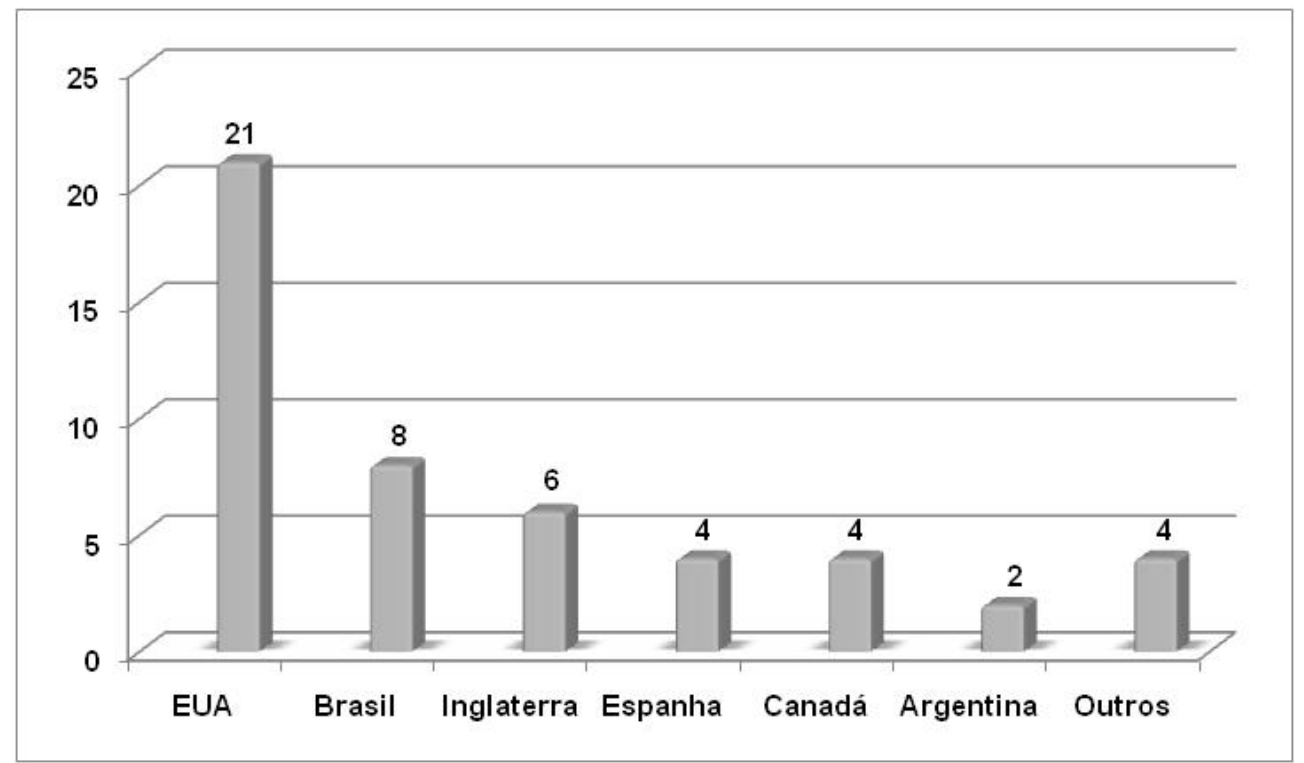

Gráfico 3 - País de origem do artigo

O país que mais contribuiu com publicações na área foi os Estados Unidos, seguido do Brasil, Inglaterra, Espanha e Canadá. Embora o tema morte e cuidados no final de vida seja mais intensamente explorado no contexto norte-americano, o Brasil destaca-se como um dos países que contribui para a ampliação do corpo de conhecimentos na área. 


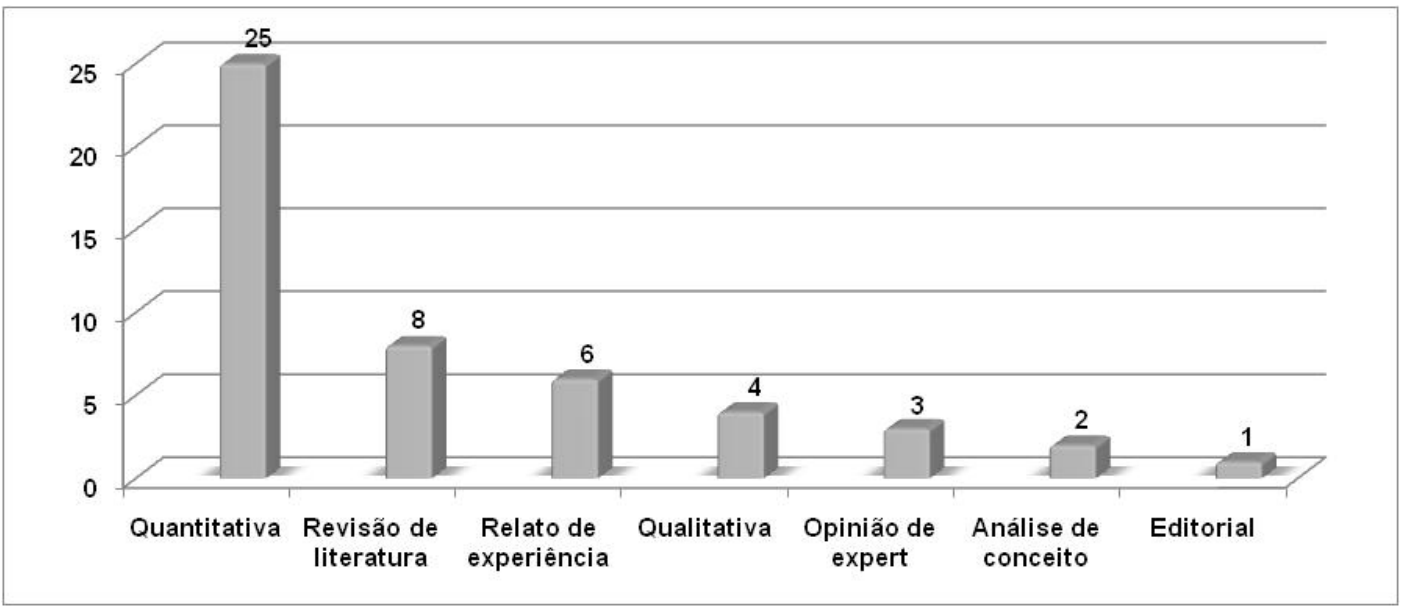

Gráfico 4 - Metodologias utilizadas

Observa-se o predomínio dos métodos de análise quantitativos, bem como pequena proporção de trabalhos que utilizaram metodologias qualitativas como métodos de análise, evidenciando que as características experiencial e de significado dos dados não são comumente trabalhadas. Ressaltam-se ainda dois trabalhos (Hendrickson, McCorkle, 2008; Welch, 2008) que utilizaram o método de análise de conceito desenvolvidos na área da enfermagem.

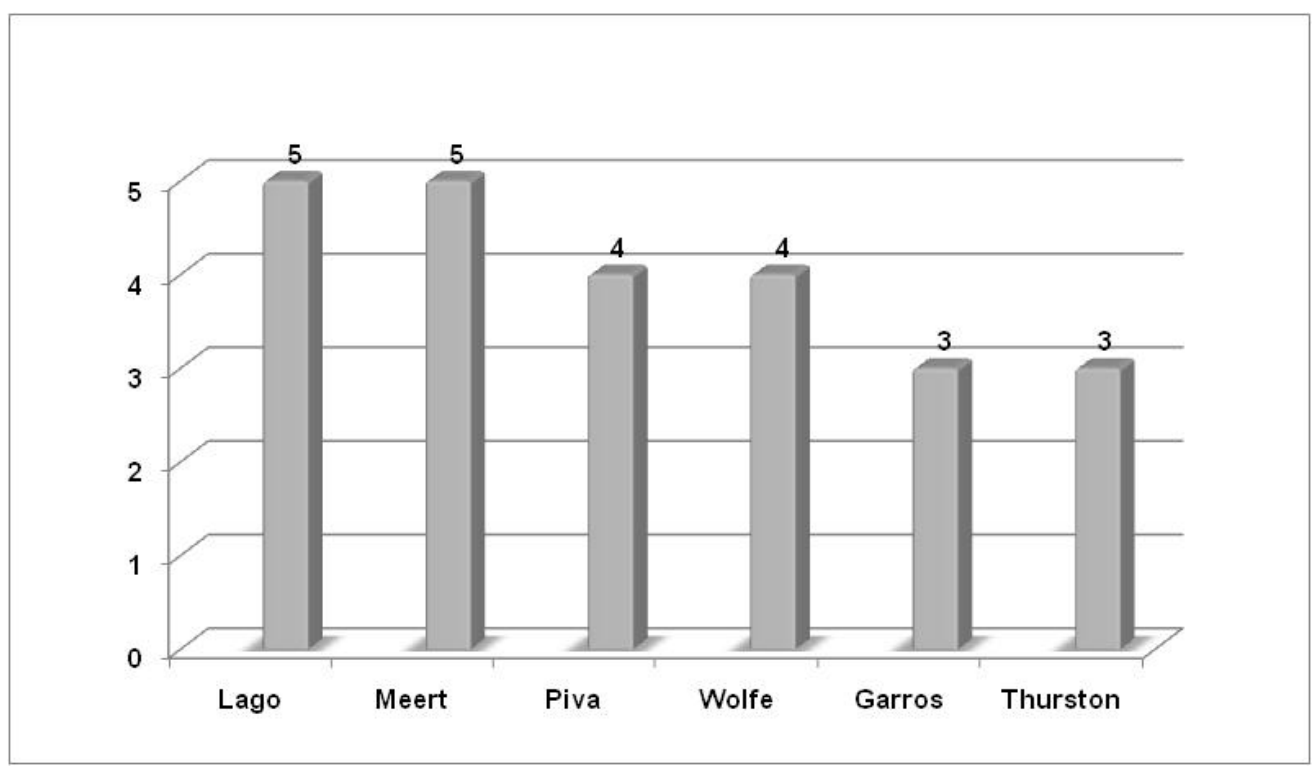

Gráfico 5 - Autores mais freqüentes

Dentre os principais autores, destacam-se: Patrícia Lago, médica da UTI pediátrica do Hospital das Clínicas de Porto Alegre e Kathleen Meert, médica do Children's Hospital of Michigan. É importante notar que dos seis autores citados, três deles são brasileiros (Lago, Piva e Garros), porém, um 
deles (Garros) atua em uma UTI pediátrica da Universidade de Alberta no Canadá e os demais atuam em Porto Alegre - RS.

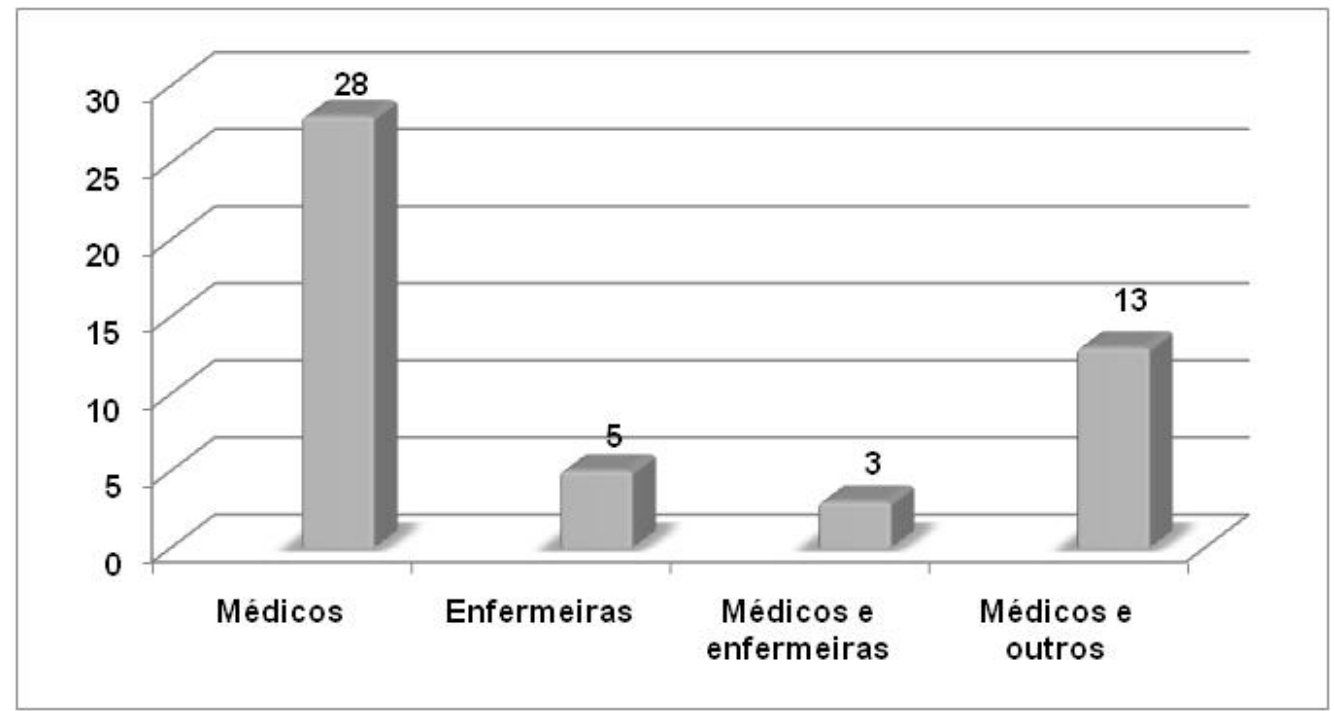

Gráfico 6 - Especialidade dos autores

Os dados evbidenciam que há um predomínio de médicos conduzindo os trabalhos nas áreas de morte e cuidados no final de vida em pediatria, provavelmente influenciados pelos intensos dilemas éticos e legais a que estão sujeitos em sua atuação profissional.

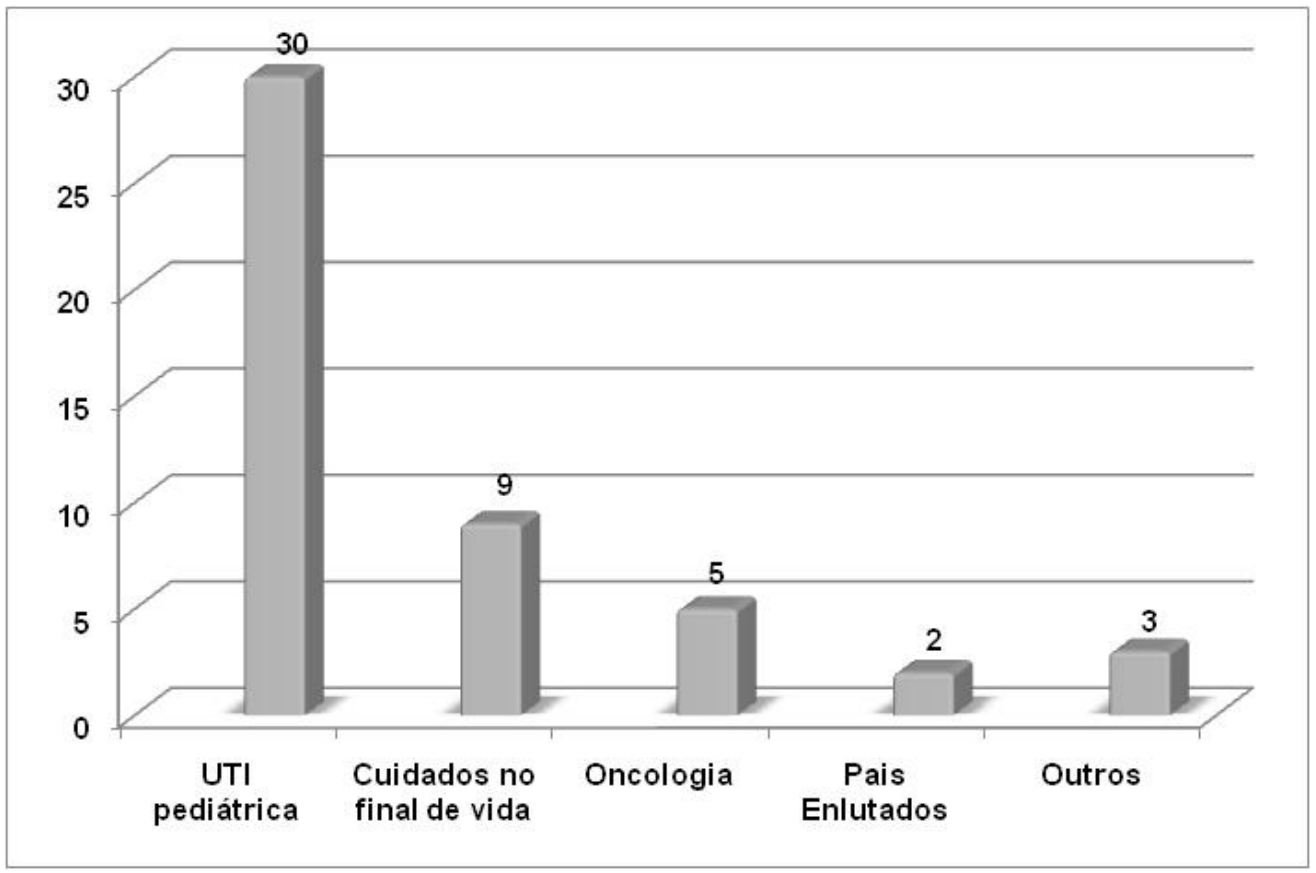

Gráfico 7 - Área em que o artigo foi desenvolvido 
Como o foco de estudo foi a morte digna na UTI pediátrica, evidentemente a maior parcela de estudos analisados foi nessa área.

Definidos os textos a serem investigados, foi feita uma leitura analítica, lendo e relendo os artigos diversas vezes, para que fosse possível selecionar as partes que realmente interessavam à pesquisa, segundo a proposta de Rodgers (1989), buscando a identificação dos elementos constituintes do conceito (origem, atributos, antecedentes e conseqüências).

Esse material foi devidamente fichado e arquivado em pasta apropriada; cada um dos 49 artigos recebeu um número, de acordo com a ordem cronológica da publicação, utilizado na categorização dos dados (APÊNDICE 1). Os dados foram estruturados utilizando-se questões norteadoras que auxiliaram a exploração dos elementos do conceito de morte digna, (Tabela 1, página 55), conforme o Quadro 1.

Quadro 1 - Organização dos artigos

Referência Vernon DD, Dean JM, Timmons OD, Banner W Jr, Allen-Webb EM. Modes of death in the pediatric intensive care unit: withdrawal and limitation of supportive care. Crit Care Med. 1993;21(11):1798-802.

Qual é a origem da morte digna da criança?

- Todos os pacientes na UTIp recebem tratamento agressivo inicialmente.

- Muitas crianças internadas em UTIp têm doenças crônicas.

- Grande número de mortes na UTIp decorre de limitação de suporte de vida.

- A limitação de suporte de vida é prática aceita em terapia intensiva.

- Não há diferença ética ou legal entre não oferecer ou suspender as medidas de suporte de vida.

- Manutenção do suporte de vida por medo dos aspectos legais por parte da equipe médica.

- Escasso registro nos prontuários quanto à limitação de suporte de vida. 
Continuação

\section{Definição do conceito}

Não consta.

De que forma a morte digna está descrita - papéis, habilidades e contexto (antecedentes)?

- Determinação de doença incurável/irreversível.

- Discutir e rediscutir as condutas de final de vida com a família.

- Consulta ao Comitê de Ética do hospital quanto às decisões de final de vida.

- Participação da equipe multidisciplinar nas decisões.

Quais as palavras ou expressões utilizadas para descrever a morte digna (atributos)?

- Limitação das medidas de suporte de vida nas situações irreversíveis.

- Participação da família nas decisões.

O que se pretende atingir com morte digna (conseqüências)?

- Preservar a autonomia da criança e da família.

A seguir, serão apresentados: a origem, as definições, os atributos, antecedentes e as conseqüências do conceito resultantes da análise crítica da literatura, incluindo dados provenientes dos artigos selecionados. 


\subsection{RESULTADOS - FASE TEÓRICA}

\section{Questão norteadora: Qual é a origem da morte digna da criança?}

\begin{tabular}{|c|c|}
\hline Origeı & Autores \\
\hline $\begin{array}{l}\text { Grande desenvolvimento tecnológico a partir da } \\
\text { segunda metade do século } \mathrm{XX} \text {, propiciando a redução } \\
\text { da mortalidade de crianças. }\end{array}$ & $3,22,26,29,39$ \\
\hline $\begin{array}{l}\text { Uso excessivo de recursos tecnológicos, provocando o } \\
\text { prolongamento do processo de morrer (distanásia). }\end{array}$ & 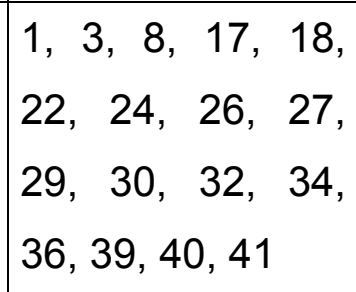 \\
\hline $\begin{array}{l}\text { Surgimento da bioética e do conceito de morte digna em } \\
\text { um contexto de intensos dilemas éticos associados ao } \\
\text { final de vida. }\end{array}$ & $3,8,24$ \\
\hline $\begin{array}{l}\text { Maioria das crianças morre nos hospitais, principalmente } \\
\text { na UTI pediátrica. }\end{array}$ & $\begin{array}{llll}10, & 12, & 13, & 16, \\
17, & 18, & 20, & 21, \\
22, & 25, & 28, & 29, \\
30, & 32, & 39, & 42, \\
43, & 44, & 47\end{array}$ \\
\hline $\begin{array}{l}\text { Maioria das crianças recebe tratamento agressivo antes } \\
\text { da morte. }\end{array}$ & \begin{tabular}{|l}
$1,10,12,17,21$ \\
$24,27,32,39,41$
\end{tabular} \\
\hline $\begin{array}{l}\text { Dificuldade de determinar estado irreversível em } \\
\text { crianças devido à grande capacidade de recuperação. }\end{array}$ & $\begin{array}{l}3,4,10,13,24, \\
25,39,40\end{array}$ \\
\hline $\begin{array}{l}\text { Muitas crianças que morrem na UTI pediátrica têm } \\
\text { doença crônica (falta de serviços especializados em } \\
\text { cuidados paliativos pediátricos). }\end{array}$ & $\begin{array}{l}1,10,14,16,17 \\
25,27,28,32 \\
34,40,44\end{array}$ \\
\hline $\begin{array}{l}\text { Tendência de limitação de suporte de vida em pacientes } \\
\text { com doenças crônicas. }\end{array}$ & $12,13,17,27,32$ \\
\hline
\end{tabular}


Continuação

Grande número de mortes na UTI pediátrica decorre de limitação de suporte de vida (a maioria das mortes é previsível) às custas de ordem de não reanimar e restrição/não-oferta de ventilação mecânica e/ou inotrópicos.
$1,2,4,9,10,11$ $13,16,17,18$ $19,21,23,27$ $28,29,30,32$, $35,36,39,40$, $41,44,46$

Fatores que justificam a limitação de suporte de vida:

Má qualidade de vida.

$4,10,11,16,17$ $19,22,24,30$, $31,36,39,46,47$

Expectativa de morte iminente a despeito dos 4, 10, 17, 22, 46 tratamentos agressivos.

Prognóstico ruim/pequena probabilidade de $3,4,16,17,24$ sobrevivência. $27,30,31,46,47$

Tratamentos fúteis. $19,36,46$

Presença de dor e sofrimento. $11,16,22,24,31$

Comprometimento neurológico. $11,19,22,24$, 30,31

Dos pontos de vista ético e legal, não existe diferença entre as formas de limitação de suporte de vida (não $1,17,27,29,32$ 36,40 reanimar, restringir ou não oferecer medidas de suporte e retirar o suporte de vida).

A limitação de suporte de vida gera receios de ordem legal/ética na equipe.

$1,4,6,17,18$ $22,26,27,32,39$ A limitação de suporte de vida em pacientes sem $1,4,13,22,27$ possibilidades terapêuticas de cura é conduta aceita dos 29, 40 pontos de vista ético e legal. 
Continuação

Antecipação da morte com analgesia/sedação justificase pelo duplo efeito das medicações.

A família é quem representa os melhores interesses da criança (os pais são os responsáveis legais pelas tomadas de decisão devido à limitação emocional e cognitiva própria do desenvolvimento da criança).

Cuidados paliativos começam a ser discutidos no contexto da UTI pediátrica.

$9,14,24,32,36$ 40

$2,3,6,10,11$ $16,22,25,27$, $30,31,33,34$ $36,39,40,41,46$ $9,16,17,18,24$ $30,35,39,41$, 42,47

Morte da criança não é um evento natural / esperado / $7,8,10,14,15$ aceitável.

$16,17,18,21$, $25,27,28,29$, $33,34,35,38$, 39,40

Profissionais de saúde são inadequadamente preparados para lidar com a morte da criança.

$6,14,20,29,30$ $33,34,40,42$, 43,44

Maior avanço dos cuidados no final de vida em $10,16,17,18$ pacientes adultos, estudos na área de pediatria são limitados.

$20,21,23,24$ $25,27,34,38$, 41,48

Aumento crescente dos estudos sobre os cuidados no $24,27,38,39$ final de vida em pediatria a partir da última década, demonstrando preocupação crescente com a qualidade dos cuidados com crianças no final de vida. 


\section{Definições de morte digna da criança}

As definições encontradas para do conceito de morte digna da criança foram:

- Preservar a autonomia da criança (Bracegirdle, 1994);

- Ausência de intervenções para prolongar a vida (Garros, 2003);

- Ausência de dor e desconforto físico (Garros, 2003);

- Ausência de dor e sintomas de desconforto (Casanueva Mateos et al., 2005);

- Seguir os princípios básicos dos cuidados paliativos (Salas Arrabide et al., 2005).

\section{Antecedentes da morte digna da criança}

Os antecedentes do conceito são situações, eventos ou fenômenos que precedem o conceito de interesse. Os antecedentes auxiliam na compreensão do contexto social no qual o conceito é geralmente utilizado, bem como favorecem o seu refinamento (Rodgers, 1989).

Questão norteadora: De que forma o conceito está descrito - papéis, habilidades e contexto?

Reconhecimento do quadro irreversível da criança

\begin{tabular}{|c|c|}
\hline Antecedentes & Autores \\
\hline $\begin{array}{l}\text { Determinação de doença irreversível ou } \\
\text { incurável / situação irrecuperável / } \\
\text { irreversibilidade de quadro clínico. }\end{array}$ & $\begin{array}{l}1,2,4,8,10,13,14,16,18, \\
19,20,21,22,23,24,25,26, \\
27,29,30,31,32,33,35,36, \\
38,39,40,41,42,44,46, \\
47,48\end{array}$ \\
\hline
\end{tabular}


Comunicação entre equipe, criança e família

\begin{tabular}{|c|c|}
\hline Antecedentes & Autores \\
\hline $\begin{array}{l}\text { Comunicação clara e efetiva entre a equipe, } \\
\text { criança e família. }\end{array}$ & $\begin{array}{l}6,7,9,10,11,12,14,15, \\
16,18,19,20,21,24,25, \\
26,28,30,33,34,35,38, \\
40,41,43\end{array}$ \\
\hline $\begin{array}{l}\text { Informações precisas, honestas e } \\
\text { congruentes para capacitar a família para } \\
\text { tomar decisões. }\end{array}$ & $\begin{array}{l}2,6,7,10,11,12,15,16, \\
17,18,23,28,39,41,43,47\end{array}$ \\
\hline $\begin{array}{l}\text { Discutir e rediscutir as condutas de final de } \\
\text { vida com a família quantas vezes forem } \\
\text { necessárias. }\end{array}$ & $\begin{array}{l}1,4,9,10,18,19,20,24 \\
39,40\end{array}$ \\
\hline
\end{tabular}

Relacionamento entre a equipe, criança e família

\begin{tabular}{l|l}
\hline \multicolumn{1}{c|}{ Antecedentes } & \multicolumn{1}{c}{ Autores } \\
\hline $\begin{array}{l}\text { Relacionamento de confiança entre a equipe, } \\
\text { família e criança. }\end{array}$ & $\begin{array}{l}3,7,11,14,15,18,20,26, \\
28,30,33,35,39\end{array}$ \\
\hline
\end{tabular}

\section{Princípios bioéticos}

Antecedentes

Princípios bioéticos nas tomadas de decisão. $3,8,11,13,17,18,19,22$, (beneficência, não-maleficência, autonomia 26, 29, 30, 31

e justiça).

Consulta à Comissão de Bioética do hospital $1,4,8,17,18,19,24,26$, nas situações dilemáticas.

\section{Autores}

27,39 


\section{Processo de tomada de decisão}

\begin{tabular}{l|l}
\hline \multicolumn{1}{c|}{ Antecedentes } & \multicolumn{1}{c}{ Autores } \\
\hline $\begin{array}{l}\text { Consenso entre a equipe médica sobre as } \\
\text { condutas de final de vida (equipe titular / } \\
\text { especialidade com a equipe da UTIp). }\end{array}$ & \\
\hline $\begin{array}{l}\text { Participação da equipe multidisciplinar nas } \\
\text { decisões até obter consenso entre os }\end{array}$ & $1,2,2,3,3,3,13,13,18,19,25,30$, \\
membros da equipe quanto às condutas no & \\
final de vida. & \\
\hline Tempo para que os pais possam aceitar a & $2,11,18,19,28,31$ \\
condição irreversível da criança e tomar & \\
decisões.
\end{tabular}

\section{Preparo profissional}

\begin{tabular}{l|l}
\hline \multicolumn{1}{c|}{ Antecedentes } & \multicolumn{1}{c}{ Autores } \\
\hline $\begin{array}{l}\text { Preparo dos profissionais de saúde para } \\
\text { trabalhar com a criança e a família no final } \\
\text { de vida. }\end{array}$ & $\begin{array}{l}6,7,14,17,18,19,20,24, \\
25,30,33,34,38,42, \\
44,49\end{array}$ \\
\hline
\end{tabular}

Trabalho em equipe multidisciplinar

\begin{tabular}{l|l}
\hline \multicolumn{1}{c|}{ Antecedentes } & \multicolumn{1}{c}{ Autores } \\
\hline $\begin{array}{l}\text { Trabalho em equipe multidisciplinar - }-7,10,14,20,21,25,30,31, \\
\text { médico, enfermeira, psicólogo, assistentes } \\
\text { social e espiritual. }\end{array}$ & $33,34,35,38,41,43,44,49$ \\
\hline
\end{tabular}

\section{Atributos da morte digna da criança}

Os atributos são palavras e/ou expressões utilizadas com freqüência pelos autores para descrever as características do conceito (Rodgers, 1989). 
Questão norteadora: Quais as palavras ou expressões utilizadas para descrever a morte digna?

\begin{tabular}{|c|c|}
\hline Atributos & Autores \\
\hline $\begin{array}{l}\text { Limitação de suporte de vida nas } \\
\text { situações de quadro clínico } \\
\text { irreversível. }\end{array}$ & $\begin{array}{l}1,2,3,4,6,8,10,16,17,18,19,20, \\
21,22,23,24,25,26,27,29,30,31, \\
32,36,39,40,41,42,44,46,47\end{array}$ \\
\hline $\begin{array}{l}\text { Respeito aos valores e crenças da } \\
\text { criança e da família. }\end{array}$ & $\begin{array}{l}3,7,8,11,13,16,18,19,20,22,24 \\
28,30,33,35,41\end{array}$ \\
\hline $\begin{array}{l}\text { Atendimento das necessidades } \\
\text { religiosas/espirituais da criança e da } \\
\text { família. }\end{array}$ & $\begin{array}{l}2,7,11,15,16,18,20,21,24,25 \\
28,30,33,34,35,39,41,47\end{array}$ \\
\hline $\begin{array}{l}\text { Participação dos pais nos cuidados } \\
\text { com a criança. }\end{array}$ & $3,28,3$ \\
\hline Participação da família nas decisões. & $\begin{array}{l}1,2,3,4,7,8,10,11,13,14,16,17, \\
18,19,20,21,22,23,24,25,26,27, \\
29,30,31,32,38,39,40,41,44,46, \\
47,48\end{array}$ \\
\hline $\begin{array}{l}\text { Participação da criança nas } \\
\text { decisões. }\end{array}$ & $\begin{array}{l}3,14,18,20,25,31,33,36,38,39 \\
42,44,46,48\end{array}$ \\
\hline $\begin{array}{l}\text { Transição do foco dos cuidados } \\
\text { curativos para os paliativos. }\end{array}$ & $\begin{array}{l}2,6,8,10,14,16,17,18,20,21,24 \\
25,30,33,34,35,38,39,41,44,48 \\
49\end{array}$ \\
\hline Avaliação e tratamento da dor. & $\begin{array}{l}2,6,7,9,10,11,12,14,16,18,19, \\
20,21,23,24,28,30,33,34,35,36, \\
38,39,40,41,48,49\end{array}$ \\
\hline $\begin{array}{l}\text { Avaliação e tratamento dos sintomas } \\
\text { de desconforto. }\end{array}$ & $\begin{array}{l}2,6,9,10,11,12,14,18,19,20,21, \\
23,24,25,28,30,33,34,36,38,39, \\
40,41,49\end{array}$ \\
\hline
\end{tabular}


Continuação

\begin{tabular}{|c|c|}
\hline $\begin{array}{l}\text { Atendimento das necessidades } \\
\text { emocionais e sociais da criança. }\end{array}$ & $\begin{array}{l}7,10,11,14,18,20,21,23,24,25, \\
33,34,38,39,41,42,43\end{array}$ \\
\hline $\begin{array}{l}\text { Atendimento das necessidades da } \\
\text { família. }\end{array}$ & $\begin{array}{l}2,3,6,7,10,11,14,15,16,18,20 \\
21,24,25,28,30,33,34,38,41,43 \\
47\end{array}$ \\
\hline Presença constante da família. & $\begin{array}{l}2,11,15,18,19,23,24,27,28,29, \\
30,35,39,40,41,42\end{array}$ \\
\hline $\begin{array}{l}\text { Preparo da família para a morte da } \\
\text { criança. }\end{array}$ & $6,23,25,28,33,34,35,42,43,49$ \\
\hline Oportunidade para despedida. & $\begin{array}{l}2,6,7,9,11,18,19,23,24,28,29, \\
30,31,41,42,47\end{array}$ \\
\hline $\begin{array}{l}\text { Ambiente apropriado e com } \\
\text { privacidade. }\end{array}$ & $2,8,18,23,28,33,39,41,42,47$ \\
\hline Política de visitação flexível. & $2,11,18,28,29,41,42,47$ \\
\hline $\begin{array}{l}\text { Oportunidade para a criança morrer } \\
\text { em outro local que não a UTI } \\
\text { pediátrica. }\end{array}$ & $\begin{array}{l}8,10,12,14,16,18,20,21,25,31, \\
38,39,41,42,44,49\end{array}$ \\
\hline
\end{tabular}

\section{Conseqüências da morte da criança}

As conseqüências do conceito referem-se a eventos ou situações resultantes da sua utilização (Rodgers, 1989). A definição precisa das conseqüências é concretizada após a exploração do conceito em sua manifestação prática.

Questão norteadora: $O$ que se pretende atingir com a morte digna da criança? 


\begin{tabular}{|c|c|}
\hline Conseqüências & Autores \\
\hline $\begin{array}{l}\text { Minimizar/aliviar a dor e o sofrimento } \\
\text { da criança. }\end{array}$ & $\begin{array}{l}2,6,7,8,9,10,12,13,16,18,19 \\
20,21,23,24,25,27,28,30,31,32 \\
33,34,36,39,40,41,44,46,47,49\end{array}$ \\
\hline $\begin{array}{l}\text { Minimizar/aliviar o sofrimento da } \\
\text { família. }\end{array}$ & $\begin{array}{l}2,3,6,7,8,9,15,28,30,31,33,39 \\
41,42,47\end{array}$ \\
\hline $\begin{array}{l}\text { Preservar a autonomia da criança e } \\
\text { da família (decisões consensuais). }\end{array}$ & $\begin{array}{l}1,2,3,4,7,8,10,11,13,14,16,17 \\
18,19,20,21,22,23,24,25,26,27 \\
29,30,31,32,33,39,40,41,44,46\end{array}$ \\
\hline $\begin{array}{l}\text { Evitar a distanásia/futilidade } \\
\text { terapêutica. }\end{array}$ & $\begin{array}{l}3,22,24,26,27,29,30,32,36,39 \\
40,47\end{array}$ \\
\hline $\begin{array}{l}\text { Satisfação da família com os } \\
\text { cuidados no final de vida (família } \\
\text { segura e confiante). }\end{array}$ & $\begin{array}{l}2,7,11,12,16,23,24,25,28,31 \\
40,41,43,47\end{array}$ \\
\hline $\begin{array}{l}\text { Facilitar o processo de luto da } \\
\text { família / melhorar a adaptação da } \\
\text { família à perda. }\end{array}$ & $\begin{array}{l}2,6,7,10,11,15,16,18,20,23,24 \\
25,28,30,33,38,41,42,43,45,48 \\
49\end{array}$ \\
\hline $\begin{array}{l}\text { Ampliar as discussões sobre os } \\
\text { cuidados no final de vida em } \\
\text { pediatria (durante a formação } \\
\text { profissional e nos locais de trabalho). }\end{array}$ & $6,8,27,30,32,34,39,42$ \\
\hline $\begin{array}{l}\text { Melhorar a qualidade dos cuidados } \\
\text { no final de vida em pediatria. }\end{array}$ & $\begin{array}{l}9,12,14,16,17,20,21,24,25,27 \\
34,38,39,40,41,43,44,47,48,49\end{array}$ \\
\hline
\end{tabular}

A síntese dos dados da Fase Teórica encontra-se no Diagrama dos Resultados - Fase Teórica, destacando-se os antecedentes, atributos e conseqüências da morte digna da criança. 


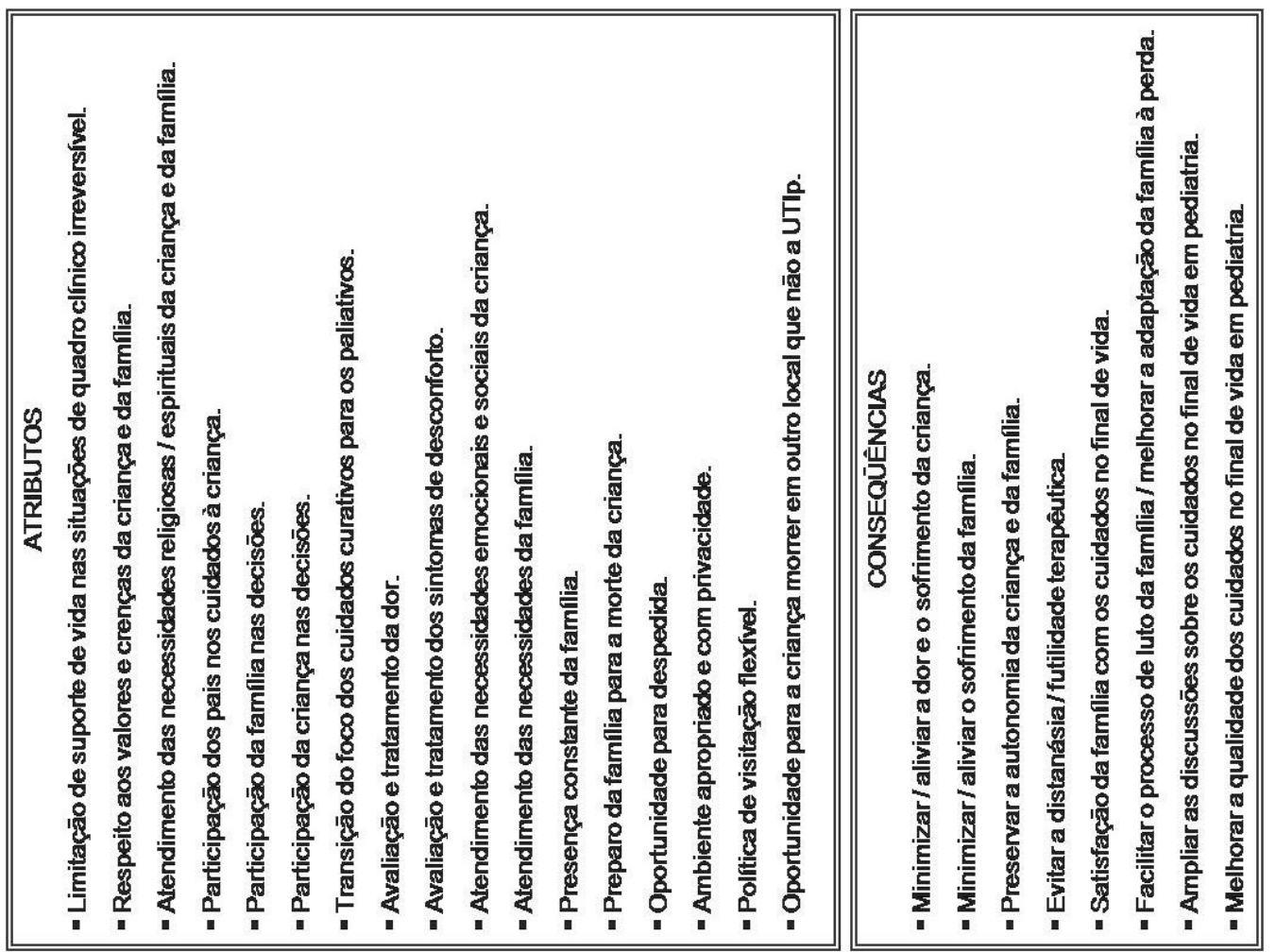

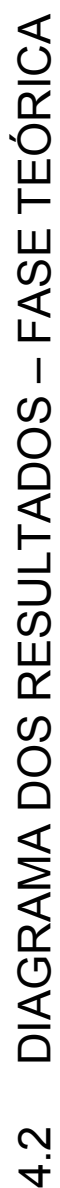

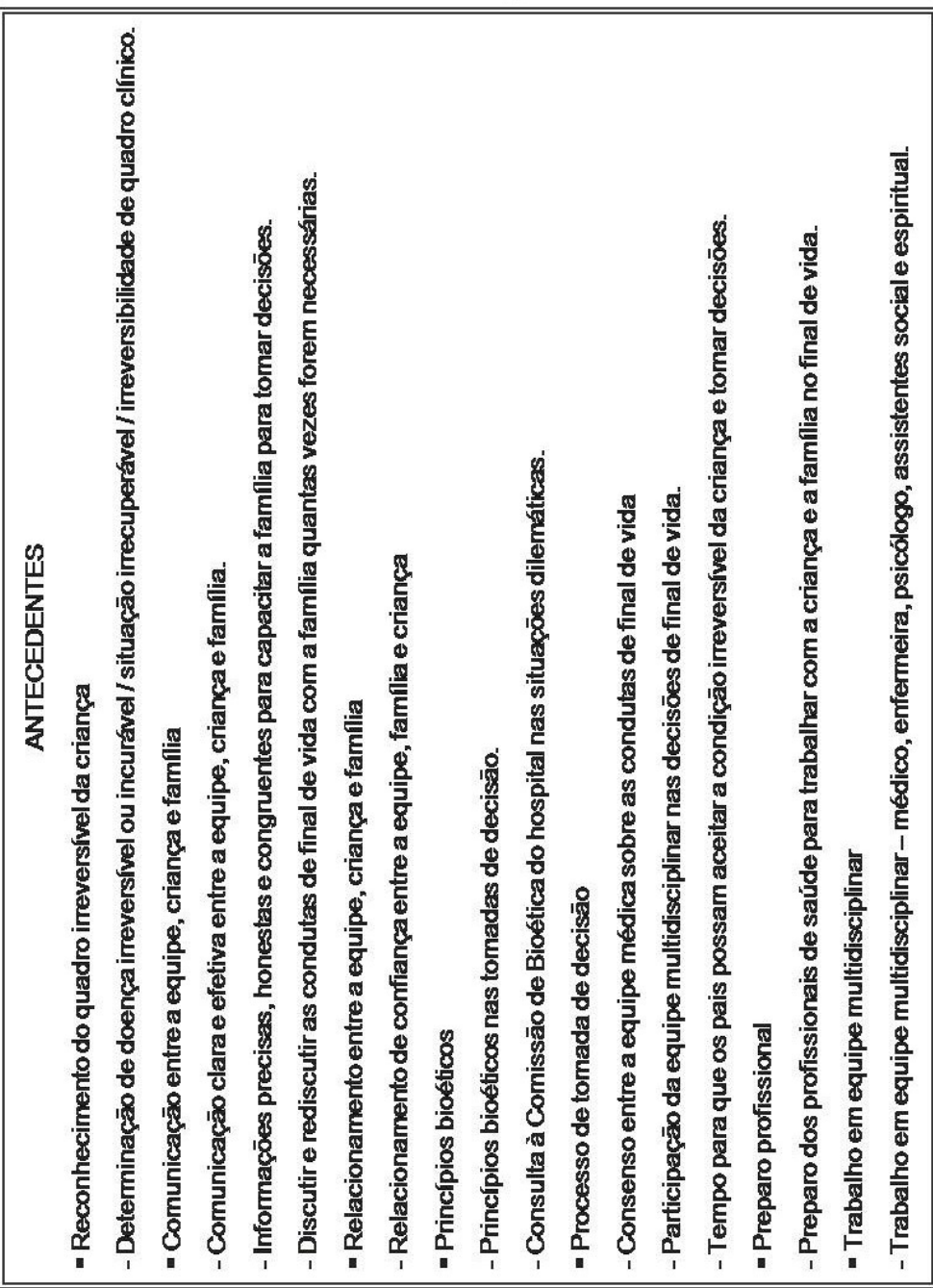


"A responsabilidade nos cabe em todos os nossos atos cotidianos, já que todos os nossos atos, sem exceção, contribuem para formar o mundo em que existimos e que legitimamos precisamente por meio desses atos.” 
De acordo com Schwartz-Barcott e Kim (2000), a Fase de Campo deve privilegiar situações onde o conceito é relevante e o investigador pode clarificar os elementos centrais deste conceito. $O$ pesquisador deve considerar a probabilidade ou freqüência de ocorrências do fenômeno em estudo no contexto investigado.

\subsection{PERCURSO METODOLÓGICO}

Os métodos qualitativos, quando utilizados nas pesquisas de desenvolvimento de conceito, propiciam a incorporação das experiências e significados atribuídos a determinadas situações para a compreensão do conceito, permitindo que este seja desenvolvido como ele é; melhor dizendo, supostamente os métodos qualitativos aumentam a validade e fidedignidade do conceito, contribuindo, sobremaneira, com o avanço da pesquisa e prática clínica. A interação simultânea entre os dados, o processo de análise e a comparação com a literatura permitem o processo de descrição, identificação, clarificação, delineamento e evolução do conceito (Morse, 1995).

A estrutura teórica que orientou a análise dos dados na Fase de Campo refere-se à Fase Teórica, conforme sugerido por Schwartz-Barcott e Kim (2000) no Modelo Híbrido de Desenvolvimento de Conceitos.

A Análise de Conteúdo foi utilizada como referencial metodológico para a análise das entrevistas dos médicos e enfermeiras que participaram da Fase de Campo. Segundo Bardin (2006), a Análise de Conteúdo pode ser definida como:

Um conjunto de técnicas de análise de comunicação visando obter, por procedimentos sistemáticos e objetivos de descrição do conteúdo das mensagens, indicadores que permitam a inferência de conhecimentos relativos às condições de produção/recepção destas mensagens.

O pesquisador que trabalha seus dados a partir da perspectiva da Análise de Conteúdo está sempre procurando um texto atrás de outro, um texto que não está aparente já na primeira leitura e que precisa de uma metodologia para ser desvendado. 
$\mathrm{Na}$ busca de atingir os significados manifestos e latentes no material estudado, têm sido desenvolvidas várias técnicas de análise de conteúdo, tais como: Análise de Expressão, Análise de Relações, Análise Temática e Análise de Enunciação (Bardin, 2006). Ao se estudar a proposta de cada uma das modalidades, observou-se que cada uma enfatiza aspectos a serem observados nos textos dentro de pressupostos específicos. Assim sendo, optou-se pela Análise Temática, por ser a forma que melhor se adequou à presente investigação.

A noção de tema está ligada a uma afirmação a respeito de determinado assunto. Ela comporta um feixe de relações e pode ser apresentada através de uma palavra, frase ou um resumo. Segundo Bardin (2006): "O tema é a unidade de significação que se liberta naturalmente de um texto analisado segundo critérios relativos à teoria que serve de guia à leitura".

Fazer uma análise temática consiste em descobrir os núcleos de sentido que compõem uma comunicação, cuja presença ou freqüência significam alguma coisa para o objetivo analítico visado. Operacionalmente, a análise temática desdobra-se em três etapas, as quais são descritas a seguir (Bardin, 2006):

a. Pré-análise - Consiste na escolha do material a ser analisado, na retomada das hipóteses e dos objetivos iniciais da pesquisa, reformulandoas frente ao material coletado, e na elaboração de indicadores que orientem a interpretação final.

b. Exploração do material - É o momento da codificação, em que os dados brutos são transformados de forma organizada e agregados em unidades, as quais permitem uma descrição das características pertinentes ao conteúdo. Para tanto, realiza-se a classificação e agregação dos dados, escolhendo as categorias que comandarão a especificação dos temas. As categorias são reflexos da realidade, sendo sínteses, em determinado momento, da experiência estudada. Por isso, modificam-se constantemente, assim como a realidade. A categorização permite reunir maior número de informações à custa de uma esquematização e, assim, correlacionar classes de acontecimentos para ordená-los. 
C. Tratamento dos resultados obtidos e interpretação - Consiste na organização dos dados brutos, de modo a se constituírem os temas, os quais podem ser definidos como unidades que se libertam naturalmente do texto analisado. Nessa fase, a reflexão e a intuição com embasamento no referencial teórico servem de fundamento para se estabelecerem relações com a realidade, aprofundando a conexão de idéias. Durante a interpretação dos dados, é preciso voltar atentamente aos marcos teóricos, pertinentes à investigação, pois eles dão o embasamento e as perspectivas significativas para o estudo. A relação entre os dados obtidos e a fundamentação teórica é que dá sentido às interpretações, que ocorrem sempre na tentativa de buscar o que se esconde sob a aparente realidade, o que significa verdadeiramente o discurso enunciado, o que querem dizer, em profundidade, certas afirmações, aparentemente superficiais.

\subsection{COLETA DE DADOS}

Os dados da Fase de Campo foram coletados em três instituições hospitalares de São Paulo que possuem UTI pediátrica. Destas, uma instituição é mista (pública e particular) (Instituição 1), uma particular (Instituição 2) e outra pública (Instituição 3). Todas elas atendem casos de grande complexidade e são centros de referência. As três UTIs contam com mais de nove leitos e possuem médicos e enfermeiras presentes na unidade nas 24 horas. Porém, na Instituição 1, as enfermeiras não ficam na assistência direta ao paciente exclusivamente, sendo responsáveis, principalmente, por tarefas administrativas/burocráticas. Nas Instituições 2 e 3, as enfermeiras são responsáveis, sobretudo, pela assistência direta ao paciente.

Para que o conceito de morte digna da criança fosse explorado em profundidade, foram acessadas as experiências de médicos e enfermeiras que cuidavam de crianças em final de vida na UTI pediátrica, pois esses profissionais, além de prestarem cuidado ininterrupto à criança e à família, são responsáveis diretos pelos cuidados que lhes são oferecidos. 
Como estratégia para a coleta de dados, foi utilizada a entrevista semi-estruturada. Os médicos e enfermeiras foram convidados a participar do estudo, expondo-se os objetivos do trabalho. As entrevistas foram agendadas em horários e locais convenientes ao entrevistado e gravadas para posterior transcrição e tiveram uma duração que variou de 50 e 120 minutos. Além disso, a pesquisadora tomou notas de tópicos importantes para auxílio na análise dos dados e formulação de questões exploratórias subseqüentes.

As questões que nortearam as entrevistas são semelhantes às que serviram de guia para exploração do material durante a Fase Teórica (Tabela 1). Procurou-se utilizar questões equivalentes nas duas fases, com a intenção de identificar os antecedentes, atributos e conseqüências tanto nos dados provenientes da literatura quanto nas entrevistas. 
Tabela 1 - Questões norteadoras

\begin{tabular}{|c|c|c|}
\hline & Fase Teórica & Fase de Campo \\
\hline 동 & $\begin{array}{l}\text { Qual é a origem da morte } \\
\text { digna da criança? }\end{array}$ & $\begin{array}{l}\text { Aspecto explorado apenas na Fase } \\
\text { Teórica. }\end{array}$ \\
\hline 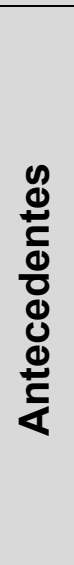 & $\begin{array}{l}\text { De que forma a morte digna } \\
\text { está descrita - papéis, } \\
\text { habilidades e contexto? }\end{array}$ & $\begin{array}{l}\text { Como uma criança pode morrer } \\
\text { dignamente? O que deve ser feito? } \\
\text { De que forma se pode promover a } \\
\text { morte digna para a criança? Quais } \\
\text { decisões da família facilitam } \\
\text { proporcionar uma morte digna para a } \\
\text { criança? O que torna possível a } \\
\text { morte digna? }\end{array}$ \\
\hline 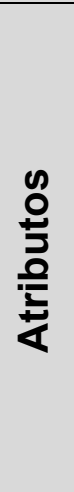 & $\begin{array}{l}\text { Quais as palavras ou } \\
\text { expressões utilizadas para } \\
\text { descrever a morte digna? }\end{array}$ & $\begin{array}{l}\text { Descreva-me uma situação na qual a } \\
\text { morte da criança tenha sido digna. O } \\
\text { que você entende por morte digna? } \\
\text { Quais palavras ou expressões você } \\
\text { acha que descrevem a morte digna? } \\
\text { Como descreveria uma morte não- } \\
\text { digna? }\end{array}$ \\
\hline 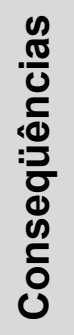 & $\begin{array}{l}\text { O que se pretende atingir } \\
\text { com a morte digna? }\end{array}$ & $\begin{array}{l}\text { Quais foram as conseqüências da } \\
\text { experiência que vivenciou } \\
\text { presenciando uma morte digna? }\end{array}$ \\
\hline
\end{tabular}

O número de médicos e enfermeiras foi se configurando em razão da análise de seus depoimentos. À medida que a análise dos dados prosseguia, buscávamos novos dados, para que as categorias fossem melhor desenvolvidas e densificadas. A coleta de dados foi realizada até acontecer a saturação teórica, quando se verificaram repetição e ausência de dados novos e crescente compreensão dos temas identificados. 
Participaram do estudo dezesseis profissionais, incluindo nove enfermeiras e sete médicos. A idade dos entrevistados variou de 28 a 56 anos. O tempo de profissão variou de quatro a trinta anos e o período de atuação em UTI pediátrica variou de três a vinte e dois anos. Com relação à especialidade dos profissionais, a maioria (81,25\%) possui especialização em Pediatria e UTI pediátrica. A caracterização detalhada dos entrevistados é apresentada na Tabela 2. 


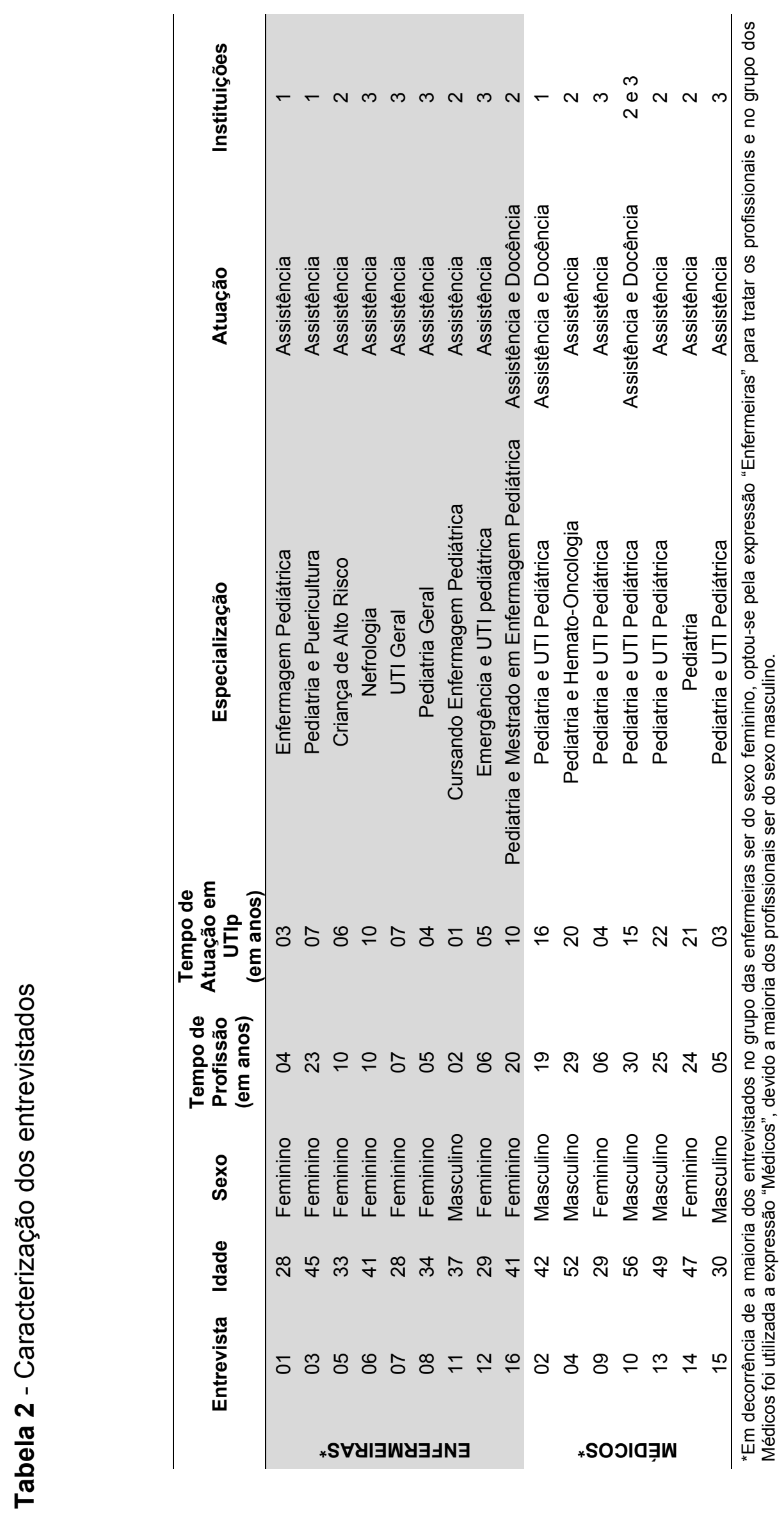




\subsection{ASPECTOS ÉTICOS}

A participação no estudo foi voluntária e, antes de cada entrevista, foi explicitado o objetivo do trabalho, ou seja, desenvolver o conceito de morte digna da criança na UTI pediátrica. A seguir, foi solicitado que o entrevistado lesse o Termo de Consentimento Livre e Esclarecido (ANEXO 1). Caso não houvesse dúvida, era requerida sua autorização formal para iniciar a entrevista. Em caso positivo, estas foram esclarecidas antes de começar a entrevista. Foi esclarecido que a participação no estudo era voluntária e que os dados permaneceriam sob a guarda da pesquisadora.

Em observação à legislação que regulamenta a pesquisa em seres humanos (Conselho Nacional de Saúde, 1996), o projeto foi apresentado ao responsável por cada uma das unidades e submetido ao Comitê de Ética em Pesquisa das referidas instituições, tendo parecer favorável em todas elas (Instituição 1 - Protocolo 091/06; Instituição 2 - Protocolo 06/396; Instituição 3 - Protocolo 534/12/2006). É importante ressaltar que a coleta de dados iniciou-se após a aprovação do projeto pelos Comitês de Ética em Pesquisa de cada uma das instituições envolvidas no estudo.

\subsection{RESULTADOS - FASE DE CAMPO}

ANTECEDENTES são situações ou eventos que precedem a morte digna da criança na UTI pediátrica. Para que o médico e a enfermeira possam proporcionar a morte digna para a criança, consideram ser necessárias as seguintes condições: EXERCícIO DE UMA PRÁTICA DE EXCELÊNCIA, IDENTIFICAÇÃO DA CRIANÇA FORA DE POSSIBILIDADE DE CURA, ACEITAÇÃO DA IRREVERSIBILIDADE, CONCORDÂNCIA DE UMA PRÁTICA PRUDENTE, SEGURANÇA PARA INCLUSÃO DA FAMÍLIA e HABILIDADE DE COMUNICAÇÃO. 
O EXERCÍCIO DE UMA PRÁTICA DE EXCELÊNCIA proporciona aos profissionais a possibilidade de eles aplicarem todos os recursos disponíveis para o tratamento da criança e utilizarem as evidências científicas para avaliarem a resposta da criança à terapêutica proposta.

Para os profissionais, a admissão da criança na UTI pediátrica representa que ela tem chance de recuperação, então, todos os recursos disponíveis tais como: monitorização cardíaca, infusão de drogas vasoativas, ventilação mecânica, hemodiálise, diálise peritoneal, hemoderivados, exames diagnósticos, cirurgias e quimioterapia, entre outros, são empregados na tentativa de restabelecer a sua saúde.

O EXERCÍCIO DE UMA PRÁTICA DE EXCELÊNCIA é o profissional ter a possibilidade de empregar toda a ciência e tecnologia que ele julga apropriadas visando a recuperação da criança. Desta forma, para os profissionais, o EXERCíCIO DE UMA PRÁTICA DE EXCELÊNCIA só é possível quando eles dispõem, no seu local de trabalho, de equipamentos, medicações e recursos diagnósticos e terapêuticos adequados para diagnosticar e tratar a patologia apresentada pela criança.

Além de aplicar todos os recursos disponíveis para o tratamento, utilizar as evidências científicas considerando tanto as evidências clínicas, quanto as da literatura para avaliar a resposta da criança à terapêutica inicialmente oferecida é outro aspecto apontado pelos profissionais no EXERCÍCIO DE UMA PRÁTICA DE EXCELÊNCIA.

"[...] por mais que a criança venha a falecer, foram tentados todos os recursos que estiveram ao alcance; então, dá para encarar como uma morte digna." (Enf. 8)

“[...] do ponto de vista de prognóstico, por exemplo, hoje a literatura preconiza que nesta criança com recidiva tumoral póstransplante a mortalidade é de 100\%.” (Méd. 13)

Quando o profissional teve a possibilidade de exercer uma prática de excelência e o tratamento mostrou-se inefetivo para proporcionar a cura, ou seja, a criança não mostrou sinais de uma possível recuperação, o médico 
inicia a IDENTIFICAÇÃO DA CRIANÇA FORA DE POSSIBILIDADE DE CURA.

Para que ocorra a IDENTIFICAÇÃO DA CRIANÇA FORA DE POSSIBILIDADE DE CURA o médico precisa acreditar que o processo de doença não se alterará com o tempo, a despeito dos recursos terapêuticos empregados no sentido de restabelecer a saúde da criança, bem como integrar razão e emoção para avaliar a situação da criança, além de assumir as limitações da medicina.

Acreditar que a criança não tem possibilidade de cura é uma condição de extrema dificuldade para o médico, já que implica estabelecer com segurança que ela é irrecuperável. Os médicos consideram que, por se tratar de crianças, a definição da irreversibilidade é um processo difícil e que demanda tempo, pois acreditam que as crianças apresentam maiores possibilidades de recuperação, quando comparadas com pacientes adultos. Para os médicos, a evolução das doenças na infância é surpreendente, tanto do ponto de vista de prognóstico como de eventuais seqüelas, tornando difícil a IDENTIFICAÇÃO DA CRIANÇA FORA DE POSSIBILIDADE DE CURA.

Quando o profissional teve a possibilidade de oferecer todos os recursos disponíveis para o tratamento e tanto as evidências clínicas, como científicas apontam para a impossibilidade de recuperação, ele começa a perceber que a criança pode não ser passível de cura. No entanto, o profissional precisa do tempo dele para constatar e assimilar a condição irreversível da criança. Este tempo é necessário para que o médico sinta-se seguro para concluir que a criança não tem mais possibilidade de recuperação.

Os profissionais referem que no caso de crianças com diagnóstico conhecido, especialmente nos casos de doenças crônicas, além de terem mais dados sobre a evolução da doença e resposta ao tratamento, eles também dispõem de um tempo maior para constatar a inefetividade do tratamento curativo, sentindo-se mais seguros para a IDENTIFICAÇÃO DA CRIANÇA FORA DE POSSIBILIDADE DE CURA. Por outro lado, para os profissionais, no caso das doenças agudas, o tempo que se dispõe para tentar recuperar a criança é limitado, além de a criança apresentar 
possibilidade de recuperação sem seqüelas, tornando mais difícil a IDENTIFICAÇÃO DA CRIANÇA FORA DE POSSIBILIDADE DE CURA.

Deste modo, nas situações em que o médico continua acreditando que a criança pode ser curada ou nas situações onde ele não dispõe de tempo para se sentir seguro com relação à inefetividade do tratamento curativo, ele opta por manter a terapêutica visando a cura que vinha sendo oferecida.

Assim, para a IDENTIFICAÇÃO DA CRIANÇA FORA DE POSSIBILIDADE DE CURA, O profissional integra razão e emoção, combinando a faculdade de avaliar a situação clínica da criança, ponderar os prós e os contras de continuar o investimento terapêutico ou não, com a percepção do sofrimento causada pela terapêutica curativa. Os profissionais apóiam-se tanto em evidências científicas, quanto naquelas provenientes de experiências pessoais de que o tratamento acarreta aumento do sofrimento para a criança, a família e a equipe, a fim de compreender as desvantagens de continuar utilizando os recursos terapêuticos. Isto significa que não é só o conhecimento técnico ou componente cognitivo que prevalece quando os profissionais avaliam a situação e identificam a criança fora de possibilidade de cura.

Então, para que aconteça a IDENTIFICAÇÃO DA CRIANÇA FORA DE POSSIBILIDADE DE CURA o profissional precisa considerar que o compromisso profissional de salvar vidas e esgotar as possibilidades tecnológicas tem menos valor do que proporcionar o alívio do sofrimento para a criança e para a família.

Desta forma, para os profissionais, reconhecer que o alívio do sofrimento passa a ser prioridade nas situações em que a criança não tem possibilidade de recuperação representa uma mudança de valores, pois eles apontam que ainda são preparados para tratar a doença e salvar vidas. Quando acontece a IDENTIFICAÇÃo DA CRIANÇA FORA DE POSSIBILIDADE DE CURA, O profissional percebe que ele pode ser "vencido" pela morte e passa a agir diante desta constatação, com o objetivo de proporcionar uma qualidade de vida melhor para a criança e a família. 
Assumir as limitações da medicina quanto às possibilidades terapêuticas e de cura leva o profissional à IDENTIFICAÇÃO DA CRIANÇA FORA DE POSSIBILIDADE DE CURA. Quando os profissionais passam a considerar que os recursos terapêuticos da medicina são limitados, ou seja, que a medicina não é capaz de resolver todos os problemas de saúde que ameaçam a vida da criança, sentem-se seguros para identificar a criança fora de possibilidade de cura como conseqüência das limitações da medicina e não como uma falha ou fracasso pessoal.

"No crônico tem um periodo em que foi tentada a recuperação e agora não existe mais chance. Uma criança aguda tem possibilidades de recuperação e de sair muito bem, mesmo quando está muito grave; então, em um paciente agudo, a gente tenta de tudo, porque ele tem a possibilidade de recuperação." (Méd. 14)

"[...] a gente também tem de sedimentar tudo [...] eu também não posso me aviltar, tenho que respeitar o meu tempo." (Méd. 4)

"Chega uma hora que a medicina tem suas limitações e que a gente não vai conseguir salvar a criança." (Méd. 15)

Após o profissional ter identificado a criança fora de possibilidade de cura, ele precisa aceitar a irreversibilidade da doença apresentada por ela, ou seja, o profissional precisa aceitar que a criança morrerá, independente dos seus esforços no sentido de recuperá-la. Para que a ACEITAÇÃO DA IRREVERSIBILIDADE ocorra, o profissional precisa ter maturidade para aceitar a morte da criança e estar preparado para lidar com a morte.

As situações de morte vivenciadas no contexto da UTI pediátrica possibilitam ao médico ter um conhecimento pessoal ou experiencial quanto ao limite de investimento terapêutico, bem como maturidade para aceitar a morte como um possível desfecho nas situações em que a criança não responde à terapêutica curativa. A percepção da enfermeira é que quando o médico é mais experiente, ele se sente mais à vontade para assumir os limites do tratamento curativo. 
Quando o profissional encara a morte da criança como a interrupção precoce da vida, ou seja, que a criança teria toda uma vida pela frente, ele tem dificuldade na ACEITAÇÃO DA IRREVERSIBILIDADE, pois, nessa situação, a morte da criança representa uma quebra do ciclo de vida, em que se espera que a criança vá crescer, se desenvolver e morrer em uma idade mais avançada. Pensar que a criança teria toda uma vida pela frente leva o profissional a ter dificuldade na ACEITAÇÃO DA IRREVERSIBILIDADE e, nessa situação, ele mantém o investimento na terapêutica curativa. Ao pensar na família, o profissional considera que para ela também é difícil aceitar a morte, por se tratar de uma criança.

Além disso, o preparo do profissional para o enfrentamento da morte facilita a ACEITAÇÃO DA IRREVERSIBILIDADE, traduzindo a importância da competência ou capacidade de avaliar e resolver as questões de final de vida da criança e tomar as melhores decisões quando a condição dela é irreversível. Isso acontece quando o profissional é treinado para trabalhar com a criança e a família nas situações de final de vida. Porém, tanto os médicos, como as enfermeiras ressaltam um déficit na formação dos profissionais de saúde com relação aos cuidados no final de vida.

Por outro lado, embora os profissionais apontem que há uma deficiência em sua formação para os cuidados de final de vida, acreditam que, atualmente, tanto os médicos quanto as enfermeiras estão mais abertos para discutir sobre os limites do processo terapêutico. Os profissionais apontam que a evolução médica, que permitiu o tratamento e a cura de diversas doenças, também acarretou situações em que o processo de morrer tornou-se difícil e prolongado, suscitando um aumento nas discussões sobre as questões relacionadas ao final de vida em pacientes que não respondem à terapêutica curativa. Além disso, no exercício de sua profissão, tanto o médico, como a enfermeira vão percebendo que a criança não é passível de cura em todas as situações e isso coloca o profissional diante da realidade de ter de conviver com a morte em seu dia-a-dia. Para os profissionais, o paradigma da vida a qualquer custo, que no início da terapia intensiva pediátrica era dominante entre a equipe de saúde, hoje 
passa a ser questionado e discutido com mais ênfase, com o intuito de diminuir o sofrimento decorrente do investimento terapêutico.

No entanto, apesar de os profissionais identificarem os avanços com relação às discussões sobre os limites do investimento terapêutico, eles ainda sentem que a morte digna ocorre a partir de esforços individuais e que não há uma discussão aprofundada sobre quando interromper o tratamento curativo, sobre a morte e o cuidar no final de vida entre os profissionais que atuam nas unidades de terapia intensiva pediátrica, justificando o porquê da morte digna partir de esforços individuais.

"Eu posso pensar em morte digna quando a pessoa já viveu o tempo necessário, chegou a hora de ela morrer e ela fez o que precisava e em uma criança a gente não consegue pensar dessa forma, em um adulto você até consegue pensar assim, porque a criança ainda teria uma vida toda pela frente... é dificil..." (Enf. 1)

"Para o médico, aceitar a morte é dificil! Então, acho que quanto mais novo maior a dificuldade de encarar a morte. Na medida em que você vai ficando mais idoso, tem a possibilidade de encarar a morte como uma coisa mais natural." (Méd. 10)

"O médico e a enfermeira foram educados na arte do curar e não na arte do enfrentar a morte." (Méd. 13)

"Se a gente considerar que a terapia intensiva pediátrica tem aí os seus trinta anos, mudou muito, ela foi incorporando conceitos e mudando com esse tempo. Essa questão do investir e do quanto investir foi normalmente sendo ventilada e discutida, então, acho que foi uma evolução natural. Hoje, a gente discute muito mais isso. No começo, a gente estava querendo reviver o indivíduo, hoje essa expectativa nem sempre ocorre, a gente tem que saber conviver com o outro lado da perda, da morte, a gente tem que saber lidar com isso. A gente aprendeu um pouquinho nesses anos todos, por isso mudou um pouquinho a ótica." (Méd. 10)

Uma vez tendo exercido uma prática de excelência, identificado a criança fora de possibilidade de cura e aceitado a irreversibilidade, o profissional busca conhecer a opinião dos outros integrantes da equipe, pois considera importante existir a CONCORDÂNCIA DE UMA PRÁTICA PRUDENTE. Para ele, precisa haver um consenso com relação à mudança 
do foco curativo para o alívio do sofrimento entre todos os profissionais envolvidos no cuidado dispensado à criança. Esta concordância precisa acontecer não só entre os profissionais da equipe da UTI pediátrica, mas também entre a equipe da UTI e a equipe titular ou da especialidade. A CONCORDÂNCIA DE UMA PRÁTICA PRUDENTE diz respeito a se atingir um consenso entre a equipe da UTI, atingir um consenso entre a equipe da UTI e da especialidade quanto à interrupção do investimento terapêutico, bem como à utilização dos princípios da bioética e da ética profissional nas situações de final de vida.

Com relação ao alinhamento das decisões quanto à interrupção do investimento terapêutico entre a equipe médica da UTI, os profissionais não vêem empecilhos, principalmente quando a equipe médica da UTI é relativamente pequena e os profissionais estão habituados a trabalhar em conjunto, sendo possível compartilhar da mesma percepção sobre o caso.

Com relação à participação dos profissionais não-médicos nas decisões sobre os limites do investimento terapêutico e cuidados no final de vida, tanto os médicos, quanto as enfermeiras consideram que a participação desses profissionais no processo de tomada de decisão é pequena e desestimulada. Isso quer dizer que, para os profissionais, as decisões de final de vida ainda são centralizadas na figura do médico. Essa situação é apontada como prejudicial para a criança, pois cada profissional envolvido no cuidado tem uma percepção diferente sobre a sua resposta ao tratamento curativo, tendo condições de contribuir para que a situação seja avaliada de forma completa e integral.

O médico atribui a disparidade entre as equipes médica e não-médica à prepotência do próprio médico decorrente de má formação para trabalhar em equipe. Isso ocorre porque o médico considera que faz atividades superiores às da equipe não-médica e que tem mais poder ou conhecimento para tomar as decisões relativas ao final de vida.

A enfermeira percebe que a sua atuação com relação à criança e à família depende das decisões tomadas pelo médico. Ela vê que sua possibilidade de conversar com a família fica limitada quando o médico não 
deixa claro que a criança não tem mais possibilidades de cura. Nessas situações, a enfermeira tenta argumentar a conduta do médico, mas percebe que a decisão final é dele e que ela tem de acatar a conduta, pois a sua participação nas decisões quanto à limitação da terapêutica curativa é restrita. Assim, a enfermeira foca a sua atenção nas atividades de cuidado, por considerar que essa é uma atribuição de sua competência, independente de a criança ter prognóstico de cura ou não.

Quando o médico não deixa claro para a família que a criança não tem possibilidade de recuperação, a enfermeira tem receio de oferecer informações que ainda não foram expostas à família pela equipe médica; em outras palavras, a enfermeira se vê limitada para conversar com a família sobre determinados assuntos que ainda não foram esclarecidos pela equipe médica e percebe a importância de o médico esclarecer a real condição da criança para a família para que ela também se sinta à vontade para falar com a família.

Com relação ao consenso entre a equipe da UTI e da especialidade, os profissionais apontam que quando existem muitas pessoas envolvidas, cada uma com um interesse particular, a CONCORDÂNCIA DE UMA PRÁTICA PRUDENTE torna-se mais difícil e prolongada, pois as várias percepções sobre as possibilidades de recuperação ou não da criança precisam ser consideradas, discutidas e analisadas, para que seja possível chegar a um consenso quanto à interrupção do investimento terapêutico. Enquanto não se chega a uma decisão consensual entre a equipe médica da UTI e da especialidade, a criança continua sendo submetida ao tratamento curativo inicialmente proposto. Os profissionais da UTI não se sentem autorizados para tomar decisões quanto à limitação terapêutica sem ter o consenso com a equipe médica da especialidade, que responde pela internação da criança.

Quando a equipe da especialidade não concorda com a limitação terapêutica proposta pela equipe da UTI, o médico intensivista intervém junto à especialidade para que haja a CONCORDÂNCIA DE UMA PRÁTICA PRUDENTE. Convencido de que o tratamento curativo não pode mais trazer 
benefícios para a criança, o intensivista se vê diante de um desafio, ou seja, fazer com que a especialidade concorde com a conduta de limitar a terapêutica curativa, com o intuito de proporcionar a morte digna para a criança. Porém, quando não há a CONCORDÂNCIA DE UMA PRÁTICA PRUDENTE, isto é, a equipe da UTI constata a irreversibilidade da doença e a equipe da especialidade opta por manter o investimento terapêutico, o posicionamento da especialidade prevalece e o tratamento curativo é mantido. No entanto, mesmo não tendo a concordância da especialidade quanto à limitação do tratamento curativo, o médico intensivista permite-se restringir alguns procedimentos invasivos ou dolorosos que não mudariam a evolução da doença.

Nestas situações, em que não há a CONCORDÂNCIA DE UMA PRÁTICA PRUDENTE entre e equipe da especialidade e a equipe da UTI, os profissionais da UTI não se sentem autorizados para conversar abertamente com a família e expor a real situação da criança. $O$ médico percebe que a falta de consenso entre a equipe da especialidade e da UTI gera insegurança na família. Nestas circunstâncias, as informações e as atitudes são conflitantes ou truncadas, pois a equipe médica da UTI está convencida da impossibilidade de cura e a equipe da especialidade continua acreditando recuperação da criança. $O$ médico se vê gerando insegurança não só para a família, mas também para a equipe não-médica, pois a ausência de consenso entre ambas as equipes resulta em condutas diferentes por parte dos intensivistas.

A CONCORDÂNCIA DE UMA PRÁTICA PRUDENTE leva os médicos e enfermeiras a não recearem o fracasso pessoal ou profissional, pois a morte da criança não pode ser atribuída a um erro ou falha de um membro da equipe, e sim como resultado de um processo de uma doença grave. Assim, a possibilidade de morte é uma realidade compartilhada por todos os membros da equipe, que se sentem seguros para proporcionar a morte digna para a criança, pois tiveram a oportunidade de oferecer todos os recursos necessários para o tratamento. 
A responsabilidade de tomar a decisão de limitar a terapêutica curativa é outro aspecto considerado pelo médico intensivista. Quando não se atinge o consenso entre a equipe da UTI e da especialidade quanto à limitação do tratamento curativo, o médico tem receio do que possa vir a acontecer, ou seja, ele teme ser responsabilizado pela morte da criança. $O$ receio de se sentir culpado ou da família culpá-lo pela morte o leva a manter o tratamento curativo. Nessas situações, o intensivista opta por não registrar com fidedignidade no prontuário da criança os procedimentos realizados e, principalmente, os não-realizados.

O receio de ser responsabilizado pela morte leva o médico a intensificar esforços no sentido de manter a criança viva, ou seja, os recursos terapêuticos são empregados com a intenção de que a criança não morra no seu plantão. Com isso, ele sente que as possibilidades de que a morte da criança seja atribuída a uma falha sua são minimizadas. Nessas situações, a enfermeira percebe que o médico age de acordo com seus próprios valores ou interesses.

Diante do receio dos aspectos legais, o médico aponta para a necessidade de se estabelecerem protocolos de condutas para as situações de final de vida como um meio de preservá-lo, pois acredita que suas ações devem ser direcionadas por um protocolo institucional e não pelo seu juízo pessoal exclusivamente. Por outro lado, percebe que é difícil estabelecer um protocolo de condutas rígidas para as situações de final de vida, pois cada caso é único e demanda de atitudes condizentes com a especificidade da situação e das pessoas envolvidas.

Outro aspecto apontado pelos profissionais na CONCORDÂNCIA DE UMA PRÁTICA PRUDENTE refere-se ao uso dos princípios da bioética beneficência, não-maleficência, autonomia e justiça - para respaldar a conduta de parar de investir na cura da criança. Os preceitos da beneficência e não-maleficência são os principais utilizados pelo médico para a deliberação nessa circunstância. Em algumas situações, os profissionais recorrem ao Comitê de Bioética da instituição para garantir o respaldo necessário para a conduta de limitar a terapêutica curativa. 
Quando o médico percebe que o investimento terapêutico acarreta mais malefícios do que benefícios, gerando o aumento do sofrimento para a criança e a família, a morte passa a ser considerada como término dos malefícios advindos do tratamento. Considerar os malefícios do tratamento versus benefícios auxiliam o profissional a direcionar sua decisão quanto à limitação do tratamento curativo. Além de se apoiarem nos princípios da bioética, os profissionais também recorrem ao suporte legislativo de sua profissão, considerando o conjunto de normas de conduta que devem ser colocadas em prática em seu exercício profissional nas situações de final de vida.

"Na UTI você só pode dançar conforme a música, às vezes, a equipe da UTI sabe que o negócio está degringolando, mas o oncologista continua dando esperança para a família. A UTI tem essa questão, as equipes médica e de enfermagem posicionam-se de acordo com o médico titular, é ele que toca a banda, ele que é o maestro, ele é quem fala o que vai fazer." (Enf. 5)

"Chegar num consenso é muito bom pra todo mundo, principalmente para a criança, porque muitas vezes a gente só prolonga uma coisa que não vai progredir, não vai tirar a criança daquele estado; então, é ideal ter uma conversa com todo mundo, inclusive a gente peca muito com isso aqui porque não tem equipe multidisciplinar decidindo, normalmente é a UTI com a especialidade médica, a enfermeira não está participando do processo, nem a fisio, a assistente social... Seria muito melhor, porque muitas vezes a enfermagem tem uma visão que a gente não tem ou a gente tem uma visão que a enfermagem não tem, mas isso acaba não acontecendo." (Méd. 9)

"A prepotência do médico acontece por má formação, a faculdade tem que trabalhar melhor nisso; a enfermagem e a medicina fazem coisas complementares, não existe superposição de funções nem comando, a enfermagem e a medicina fazem coisas diferentes, complementares, só que na visão médica, ele ainda faz coisas superiores." (Méd. 13)

"Quando não há consenso, mantém mais ou menos o que está programado, aqui, em particular, segue a orientação do médico responsável, mas é lógico que também eu, como intensivista, não vou além dos procedimentos de sustentação, não vai fazer nenhum exame ou procedimento que não vai mudar nada, como coleta de exames dolorosos, massagem cardiaca, então, como intensivista, a gente pode não fazer isso." (Méd. 10) 
"Em termos de registro, muitas vezes a gente não faz nada e é orientado pela chefia que se escreva que foram feitas manobras de reanimação, que não respondeu, evoluindo para óbito. É uma falsificação na verdade, porque não é a realidade. Em outras situações, registra-se assim: evoluiu com parada e constatado óbito tal hora, ou seja, escreve-se telegraficamente, não deixando claro se a equipe fez ou deixou de fazer [...] sempre tem aquele medo da parte legal." (Méd. 2)

Incluir a família nas decisões demanda que os profissionais tenham HABILIDADE DE COMUNICAÇÃO para interagir com ela nas situações de final de vida. A HABILIDADE DE COMUNICAÇÃO consiste na capacidade dos profissionais de trocar ou discutir idéias, dialogar, conversar, com vista ao bom entendimento entre a equipe e a família, visando a concordância de opiniões quanto às condutas a serem tomadas diante do quadro clínico irreversível da criança.

A HABILIDADE DE COMUNICAÇÃO é a aptidão do profissional para conversar abertamente com a família, expondo suas idéias de maneira sensível, empática e honesta, desenvolvendo cumplicidade com a família. Assim, nas situações em que o profissional não dispõe de tempo para estabelecer um vínculo com a família, ele percebe que a possibilidade de se comunicar com ela de forma efetiva fica reduzida, pois considera que sua HABILIDADE DE COMUNICAÇÃO está relacionada ao conhecimento que ele tem da família. Em outras palavras, para o profissional estabelecer um diálogo aberto com a família precisa de tempo para conhecê-la e ser conhecido por ela. Nestes casos, o profissional tem mais subsídios para conversar com a família, pois teve um tempo para conhecer as experiências, necessidades e reações da família.

A empatia contribui para a HABILIDADE DE COMUNICAÇÃO do profissional. Mostrar-se empático representa que o profissional tenta sentir o que sentiria caso estivesse na situação da família, imaginando como está sendo a sua experiência com a criança na UTI e tentando compreender o sofrimento vivido por ela. Quando o profissional está sensibilizado com a situação vivida pela família, ele busca compreender a sua experiência e, conseqüentemente, se dispõe a estabelecer uma comunicação transparente e efetiva com a família, pois entende que essa atitude a auxiliará a enfrentar 
a morte da criança. Neste sentido, a honestidade nas colocações sobre a situação da criança também contribui para que o profissional tenha HABILIDADE DE COMUNICAÇÃO.

O médico percebe a importância de ser honesto com a família, mantendo uma comunicação de forma transparente com ela e colocando a sua percepção da realidade de maneira clara e direta. O médico acredita que quando é honesto com a família, ele conquista a sua confiança e, com isso, desenvolve cumplicidade com a família. A enfermeira se vê num papel complementar ao do médico, pois nas situações em que a família não se sente devidamente esclarecida pela equipe médica, ela se mostra disponível para sanar as suas dúvidas, o que também predispõe o desenvolvimento de cumplicidade com a família.

Assim, a cumplicidade com a família depende tanto de uma atitude empática por parte dos profissionais envolvidos no cuidado à criança, como de honestidade, características que permitem o desenvolvimento de uma relação de confiança entre a equipe e a família. Nessa situação, o profissional vê a família como co-participante das decisões, especialmente nos casos crônicos, devido ao tempo de convívio e à possibilidade de estabelecer um vínculo com ela. Assim, para que seja possível desenvolver cumplicidade com a família, é necessário convivência, oportunidade para conhecê-la e ser conhecido por ela.

"Eu acho importante a gente se colocar um pouco na situação do outro, isso eu falo direto aqui nas reuniões, porque a mãe é chata, o pai é chato, a criança é chata, isso existe é óbvio, mas se a gente se colocar um pouco no lugar do outro, talvez a gente consiga entender a situação.” (Méd. 13)

"É muito importante fazer isso, se colocar, ser honesto, porque aí eu acho que se consegue uma cumplicidade." (Méd. 4)

"Muitas vezes, a mãe não pergunta para a equipe médica, daí ela começa a criar uma confiança, só pelo fato de ter abordado; então, começa a se formar um vínculo de confiança, aí a mãe vem perguntar todos os dias e, a partir daí, diariamente, de acordo com o que vai acontecendo, a mãe vai conversando com a gente e aí tento aparar alguma coisa que ela acha que não está bom." (Enf. 3) 
"Estabelecer vínculo não é uma coisa que a gente consegue da noite para o dia; com o tempo, a gente vai mostrando a nossa postura, a maneira como a gente conduz as coisas, como a gente resolve os problemas, a preocupação com a situação, o envolvimento..." (Enf. 16)

Para que ocorra a morte digna, o médico dispõe-se a abrir um espaço para conversar com a família para que ela possa expressar seus anseios e dúvidas. Isso é facilitado quando o profissional tem cumplicidade com a família, levando o profissional a expor sua autopercepção com segurança. Para os profissionais, é freqüente a família antever a possibilidade da morte antes que eles toquem nesse assunto. Então, abrir um espaço de conversa com a família torna-se fundamental e isso ocorre quando o profissional tem SEGURANÇA PARA INCLUSÃO DA FAMÍLIA.

A SEGURANÇA PARA INCLUSÃO DA FAMÍLIA refere-se à autoconfiança e segurança do médico para comunicar a família sobre a irreversibilidade do quadro clínico da criança quando há um consenso sobre a limitação do tratamento curativo entre os profissionais envolvidos no cuidado. Nessa situação, o médico está seguro para abrir um espaço para conversar com a família sobre a condição da criança e as condutas a serem tomadas.

Quando o profissional tem SEGURANÇA PARA INCLUSÃO DA FAMÍLIA, ele pode encontrar resistência quanto à aceitação de limitar o investimento terapêutico por parte da família. Nessa ocasião, o profissional se vê tendo de lidar com as crenças da família com relação à expectativa de cura, ou seja, a equipe está convencida de que a criança não tem chance de recuperação e a família continua acreditando que a criança pode sobreviver.

Porém, para os profissionais, não é razoável pensar que os pais possam aceitar de forma passiva qualquer tipo de limitação terapêutica num primeiro momento em que se discute, sem antes esgotar todas as possibilidades. Os profissionais consideram que aceitar a morte de um filho é um processo doloroso e prolongado, por isso percebem a importância de estarem disponíveis para discutir as condutas de final de vida com a família. 
Nos casos em que a família tem um período maior de convivência com a doença, bem como dispõe de tempo para perceber a inefetividade do tratamento, como nos casos de doenças crônicas, os profissionais percebem que, nestas situações, há uma possibilidade maior de aproximação da família, fazendo com que o profissional tenha SEGURANÇA PARA INCLUSÃO DA FAMÍLIA. Conhecer a família e ser conhecido por ela leva o profissional a se sentir seguro para discutir as condutas de final de vida com a família, tornando-a partícipe do processo de tomada de decisão. Neste sentido, o profissional percebe que a família precisa de um tempo para aceitar a possibilidade de morte da criança.

Fazer conhecer ou revelar suas próprias idéias ou juízos com relação ao quadro apresentado pela criança é uma estratégia adotada pelos profissionais na tentativa de auxiliar a família a refletir sobre a interrupção do investimento terapêutico. Quando os profissionais têm SEGURANÇA PARA INCLUSÃO DA FAMÍLIA, eles se sentem confortáveis para expor a ela a sua percepção ou opinião com relação às possibilidades de recuperação ou não da criança.

Quando o médico acredita que a família não consentirá com a sua decisão de limitar a terapêutica, ele vê uma barreira entre ele e a família, não tendo SEGURANÇA PARA INCLUSÃO DA FAMÍLIA, quando decide, então, não compartilhar com a família o seu posicionamento.

Uma outra situação apontada pelo médico refere-se àquela em que ele dispõe de um tempo limitado para estabelecer um vínculo com a família. Nesses casos, ele considera que não deve incluir a família nas decisões e que tem de assumir o ônus da decisão, sem que a família arque com a responsabilidade de decidir pela interrupção do tratamento curativo. Para o médico, essa atitude é uma forma de proteger a família da sobrecarga de decidir pela vida ou pela morte do filho.

\footnotetext{
"Nos casos oncológicos, como entre o diagnóstico e o fim da vida tem um tempo, um tratamento, muito sofrimento envolvido, tem vários passos, primeiro é o sofrimento do diagnóstico, depois o sofrimento do tratamento, depois o sofrimento da recidiva... parece que as pessoas vão se acostumando com a idéia de que a criança vai embora e que se fez tudo que podia fazer." (Méd. 4)
} 
"Tanto para a enfermeira como para o médico, a nossa maior função enquanto acompanhamento de uma internação de qualquer criança, mas principalmente da grave, é sentar com a família e dar um painel esperado com a nossa experiência do que a gente acha que vai acontecer." (Méd. 13)

"Parte dos médicos essa competência de fazer a limitação, esse ônus de dizer: 'Daqui para frente, não há mais o que investir'. Esse ônus de assumir essa postura tem que ser do médico e partilhar com a família às vezes sim, às vezes não. Às vezes é melhor não partilhar, depende do conhecimento de como é a família, se a gente tem um convívio com a família, se a gente a conhece, tem abertura para discutir com a família... Aí é até interessante partilhar disso; mas quando a gente tem um tempo hábil pequeno de conhecimento da família, o médico tem que assumir esse ônus, ou seja, limitar os processos terapêuticos ou diagnósticos, sabendo que isso não vai mudar muito. Então, é limitar mesmo e deixar esse ônus que a criança vai morrer com o médico e não passar para a família decidir." (Méd. 10)

Os ATRIBUTOS são as características essenciais próprias do conceito de interesse em contextos distintos; neste caso, são as peculiaridades que compõem a morte digna na UTI pediátrica. Os atributos da morte digna na UTI pediátrica são: RECONHECER OS BENEFÍCIOS DA EVOLUÇÃO NATURAL DA DOENÇA, RESPEITAR OS ASPECTOS SOCIOCULTURAIS, ESTABELECER UMA PARCERIA ENTRE A EQUIPE E A FAMÍLIA, PROPORCIONAR CONFORTO FÍSICO e PROMOVER O BEM-ESTAR.

RECONHECER OS BENEFÍCIOS DA EVOLUÇÃO NATURAL DA DOENÇA refere-se à postura de os profissionais admitirem a vantagem ou proveito de permitir que a evolução natural da doença que levará à morte ocorra. As ações dos profissionais nesse sentido são: não reanimar a criança em uma situação sabidamente irreversível, não introduzir uma terapêutica que não reverterá a situação, ou ainda, limitar o tratamento que a criança está recebendo, por exemplo, diminuir a infusão de drogas vasoativas ou dos parâmetros da ventilação mecânica. Nessas situações, os profissionais consideram que o sofrimento da criança e da família pode ser minimizado, quando não se prolonga uma situação sabidamente irreversível. 
"Essa criança acabou tendo uma morte bastante digna, porque na hora $\mathrm{H}$ mesmo, quando a coisa estava no final, quando se viu que não tinha nenhuma expectativa, ninguém ficou fazendo manobras heróicas." (Méd. 4)

"A criança parou na hora que tinha que parar... fez o que tinha que fazer, os recursos acabaram e ela morreu na hora que ela tinha que morrer... acho que isso é morrer dignamente." (Enf. 5)

O médico e a enfermeira reconhecem que RESPEITAR OS ASPECTOS SOCIOCULTURAIS - valores, relações, interesses, comportamentos, valores espirituais - é fundamental para estabelecer uma parceria com a família. Assim, buscam conhecer e respeitar a percepção da família em relação à expectativa de cura da criança. Os profissionais consideram que o seu papel é informar e orientar a família sobre a condição da criança, para facilitar sua participação nas decisões.

A percepção da família com relação ao cuidado dispensado à criança também é importante para os profissionais, pois eles percebem que as expectativas e demandas da família podem ser diferentes do que a equipe supõe que seja o ideal. Diante disso, o profissional reconhece que não pode ser rígido em suas condutas, devendo ter flexibilidade para atender as necessidades colocadas pela criança e pela família.

Outro aspecto apontado pelos profissionais diz respeito à prática religiosa e espiritual da família. Para eles, a família deve ser respeitada em sua prática religiosa e espiritual, recebendo todo o apoio necessário para enfrentar a morte da criança.

“O que a família julga importante freqüentemente não é o que a gente julga, a visão deles sobre o conforto para o filho pode ser diferente da nossa visão, da enfermeira e do médico. Então, ela vai pedir o que ela acha que é importante enquanto conforto. É importante discutir com a familia o que gera alegria para essa familia, o que gera alegria, conforto para essa criança e permitir isso." (Méd. 13)

"A gente tem que respeitar o que a família diz que é significativo e importante para ela, a dignidade vem daí, daquilo que a família considera importante." (Enf. 16) 
"Eu acho importante para a família sentir que naquele momento ela tem todo o apoio religioso, espiritual, dependendo da religião de cada familiar, para que a família elabore esse momento de maneira mais tranqüila." (Enf. 16)

\section{ESTABELECER UMA PARCERIA ENTRE A EQUIPE E A FAMÍLIA}

diz respeito ao consenso entre a equipe e a família quanto à interrupção do tratamento curativo, para que o foco da assistência mude da abordagem curativa para uma abordagem direcionada ao conforto físico e promoção do bem-estar da criança.

Para os profissionais, a criança não é autônoma para tomar as decisões quanto à interrupção do tratamento curativo, devido à limitação emocional e cognitiva própria do seu desenvolvimento. Assim, os pais assumem a responsabilidade pelas decisões de final de vida, representando os melhores interesses da criança.

Quando a família concorda com a interrupção do tratamento direcionado para a cura, o profissional sente-se à vontade para implementar as ações que ele considera apropriadas para a situação. Nesse momento, o profissional faz uso de alguns princípios dos cuidados paliativos, como proporcionar o conforto físico e promover o bem-estar, para direcionar a assistência à criança no final de vida.

Nessa situação, o cuidar sobrepõe-se à ideologia de cura, pois a atenção e dedicação dos profissionais estão voltadas para o conforto da criança e da família, mais do que manter idéias voltadas para a recuperação da criança. Tradicionalmente, o foco da medicina é a cura, tendo como objetivos diagnosticar e tratar a doença, através de intervenções altamente tecnológicas. No entanto, o cuidado tem como objetivo principal manter o bem-estar e está associado a numerosas características, tais como: honestidade, paciência, compaixão, empatia, respeito e proximidade. Quando o médico se propõe a proporcionar a morte digna, ele volta sua atenção para as atividades de cuidado.

Para a enfermeira, o cuidado independe da possibilidade de cura ou não da criança. Ela considera que cuidar da criança é seu principal papel, 
independente da gravidade ou condição irreversível da doença. O cuidado, na sua perspectiva, consiste nas atividades que ela vinha realizando durante toda a permanência da criança na UTI, tais como: higienização, mudança de decúbito, avaliação e controle dos sintomas de desconforto, entre outras.

Para a enfermeira, o cuidar é uma forma de ser, de se relacionar e constitui a essência de enfermagem. Neste sentindo, o cuidar é contextual, relacional, existencial e, dessa forma, é construído entre o ser que cuida e o que é cuidado. $O$ foco no cuidado em nenhuma hipótese rejeita os aspectos da ciência, apenas pretende desmistificar o fato de que o que contém emoção, sensibilidade e intuição não é conhecimento. Cuidar é o ideal moral da enfermagem, cujo fim é a proteção, a promoção e a preservação da dignidade humana.

"Quando o paciente está em situação que não responde, chamo a família e converso e chega a um acordo." (Méd. 4)

"Eu acho que ele não sofreu, porque a gente fez a sedação, tirou as drogas, não fez hemodiálise nem passou cateter, pelo menos ele não morreu sangrando, porque a gente vê muitas dessas crianças que a gente faz tudo até o final e a criança morre sangrando ou deformada, edemaciada e faz massagem e ele não; acho que o óbito foi mais tranqüilo pra ele, pra família e pra equipe." (Méd. 9)

"Da parte da enfermagem, nada muda, nada muda, embora a criança esteja na situação de sem possibilidade, nada na nossa rotina de cuidados de enfermagem muda em virtude desse diagnóstico." (Enf. 16)

PROPORCIONAR CONFORTO FÍSICO evidencia as ações dos profissionais no sentido de aliviar a dor e os sintomas de desconforto na fase final da doença, principalmente respiratório. Os profissionais utilizam a analgesia e a sedação, pois eles consideram que essas medicações podem fazer com que o os sintomas de dor e desconforto sejam minimizados ou aliviados.

O médico sente-se seguro para prescrever analgésicos potentes (opióides) e sedativos, mesmo que isso signifique antecipar a morte, como conseqüência da depressão respiratória causada por essas 
medicações. O médico considera essas reações como duplo efeito das medicações, ou seja, pesando os benefícios e os potenciais prejuízos da medicação, ele acredita que vale a pena oferecer a sedação e analgesia para a criança no final de vida, mesmo que essa conduta provoque a antecipação da morte.

"A gente dá conforto na parte da dor, deixa a criança sem dor, com analgesia o máximo possivel, se ela está começando a ficar desconfortável a gente seda para que ela fique sem esse desconforto, sem esse sofrimento no final da vida, acho que isso é o mais importante para essas crianças." (Méd. 15)

"A gente entra com medidas que tornem menos doído para a criança esses momentos finais, através de analgésicos, sedativos." (Enf. 16)

"Quando a sedação antecipa a morte, eu não acho que é eutanásia, é um efeito adverso, é o duplo efeito da medicação, você tem que fazer para sedar e é um efeito da medicação, um efeito adverso, mas eu não acho que é eutanásia, eu não estou matando, eu estou aliviando e o fato dele parar de respirar é uma conseqüência da dose que eu estou dando para ele ficar tranqüilo." (Méd. 9)

Morrer dignamente implica também em PROMOVER O BEM-ESTAR da criança. Neste sentido, os profissionais procuram concretizar ações que proporcionam bem-estar para a criança no final de vida, por exemplo, ter a presença da família, poder fazer ou comer o que gosta, receber visitas ou ter alta do hospital.

Ao pensar em PROMOVER O BEM-ESTAR, a enfermeira interage com a criança, seja conversando, seja brincando ou fazendo algum gesto que demonstre que ela se importa com o que a criança está vivenciando. Devido à proximidade com a criança durante as atividades de cuidado, a enfermeira tem a oportunidade de desenvolver um relacionamento afetivo com ela.

"Dar conforto para a criança é permitir que ela faça todas as coisas que efetivamente ela queira e que não vá provocar nenhum problema para ela. Já vi criança terminal querendo tomar Coca- 
Cola e o colega não prescreve nem a pau, ela quer que venha um primo e a visita é proibida, quer que a avó e o pai fiquem no quarto e é vetado radicalmente. Eu acho que a gente tem que tentar na medida do possivel individualizar o atendimento." (Méd. 13)

"Muitas vezes, eu não sabia o que dizer para a criança, aí eu ficava quieta, fazia um carinho..." (Enf. 6)

Os profissionais consideram que para PROPORCIONAR CONFORTO e PROMOVER O BEM-ESTAR, é necessário ter um ambiente favorável, que permita atender as necessidades da criança e da família no final de vida, garantindo sua privacidade e conforto. A permanência da criança fora de possibilidades de cura na UTI é considerada um transtorno, pois ela força uma mudança nos procedimentos habituais que visam a recuperação, tais como: monitorização contínua, passagem de cateter, diálise, atendimento à parada cardiorrespiratória etc. A UTI é vista pelos profissionais como um lugar inadequado para a permanência da criança e da família no final de vida, pois elas demandam uma assistência diferente do que a equipe da UTI é treinada para oferecer.

Os profissionais apontam para a necessidade de ter uma unidade de cuidados paliativos, ou seja, uma unidade específica para atender as demandas da criança e da família no final de vida, como o conforto, bemestar e privacidade. Os profissionais consideram que nem a UTI nem a enfermaria são lugares adequados para os cuidados à criança durante o final de vida, devido à rotina dessas unidades ser planejada para o tratamento e a cura das doenças e não para o cuidado visando conforto e bem-estar. Para os profissionais, o ideal seria ter uma unidade específica de cuidados paliativos, onde a criança e a família pudessem permanecer quando se reconhece a impossibilidade de cura, pois eles acreditam que tanto a criança como a família precisam de um atendimento diferente daquele oferecido na UTI ou enfermaria.

"Se a criança é terminal e resolveu não fazer mais nada, acho importante deixar ela num ambiente tranqüilo, não aqui no meio da UTI." (Méd. 15) 
"Geralmente, a UTI está muito cheia, muita correria, muita coisa para resolver.” (Enf. 7)

"Eu acho que o paciente estava no lugar errado, acho que nem era para estar aqui na UTI, nem na enfermaria, tinha de ter um lugar de cuidados paliativos, tinha que ter um lugar mais específico, onde tem menos tumulto. Na UTI, é tumultuado, as luzes ficam acesas, tem procedimento e passa o carrinho de parada e o pessoal sai correndo e fala alto, passa especialista... Tinha que ser um lugar onde as coisas são mais slow motion e ter um lugar adequado para ficar pai e mãe, para entrar um padre se precisar, acho que um lugar diferente, um tratamento diferente para aquele paciente." (Méd. 9)

CONSEQÜÊNCIAS são eventos ou situações que acontecem como resultado da ocorrência da morte digna na UTI pediátrica, ou seja, são situações desencadeadas pela aplicação do conceito na prática clínica. As conseqüências que compõe o conceito de morte digna na UTI pediátrica são: SOFRIMENTO MINIMIZADO, RECIPROCIDADE NAS RELAÇÕES, EQUIPE E FAMÍLIA SEGURAS e VALORIZAÇÃO DO CUIDADO ESTÉTICO.

SOFRIMENTO MINIMIZADO para a criança e a família é uma das conseqüências da morte digna na UTI pediátrica. Quando os profissionais tiveram a possibilidade de reconhecer os benefícios da evolução natural da doença, respeitar os aspectos socioculturais, proporcionar conforto físico e promover o bem-estar, eles proporcionam o alívio ou redução do sofrimento tanto para a criança como para a família.

Quando os profissionais percebem o SOFRIMENTO MINIMIZADO, eles sentem que fizeram o seu papel de assistir à criança e à família no final de vida e se sentem realizados com a assistência prestada. Por outro lado, quando não conseguem proporcionar uma morte digna, consideram que o atendimento prestado foi ruim e que ele não foi capaz de minimizar o sofrimento da criança e nem da família no final de vida.

"Embora esse momento seja bastante dolorido e traumático, foi uma situação em que o sofrimento foi minimizado.” (Enf. 16) 
"Quando não se consegue proporcionar uma morte digna, mesmo que não esteja tão consciente, no subconsciente a gente sabe que foi um atendimento ruim, uma coisa incompleta e isso faz mal para a gente mesmo, para a equipe inteira." (Méd. 2)

A RECIPROCIDADE NAS RELAÇÕES reflete a troca ocorrida entre a equipe e a família, por terem compartilhado a experiência de final de vida da criança. Nessa situação, existe o respeito e a confiança da família pelos profissionais e vice-versa. A confiança da família na equipe, construída nas interações entre eles, onde os profissionais demonstraram confiabilidade, integridade e preocupação genuína com o bem-estar da criança, faz com que a família perceba que os profissionais ofereceram o melhor cuidado para a criança. Quando os profissionais recebem o reconhecimento da família, percebem que cumpriram o seu papel de assistir com competência as necessidades da criança no final de vida.

"Eu tento conversar bastante com a mãe. Muitas mães, depois que a criança morreu, vieram e me agradeceram, me abraçaram, agradeceram por tudo." (Enf. 12)

"Eu vejo que se a gente consegue que aquela criança tenha uma morte digna com a família perto, claro que o sofrimento envolve isso, mas já me sinto realizado. Quando isso acontece, freqüentemente, a familia vem e agradece, reconhece o que foi feito." (Méd 4)

EQUIPE E FAMÍLIA SEGURAS representa que tanto a equipe como a família sentem que os melhores interesses da criança foram preservados, ou seja, embora a criança tenha morrido, ela recebeu todo o cuidado e assistência necessária durante o processo de doença. Quando a equipe e a família têm a convicção de que interromper o tratamento curativo é a decisão mais acertada para a situação, sentem-se tranqüilos e não têm a sensação de que deixaram de fazer algo que pudesse mudar o curso natural da doença.

"Acho importante que a família perceba que a criança está sendo bem cuidada, que não está sofrendo. Então, quando ocorre o óbito ela já elaborou, ela se sente tranqüila por ter feito tudo que podia, tudo que estava ao alcance." (Enf. 16) 
"O principal é deixar todo mundo tranqüilo de que não estou fazendo porque não é para ser feito..." (Méd. 9)

"Na morte digna tem que estar muito claro para a família o que está acontecendo, é a maior busca que a gente tem na verdade, se está claro para ela que eles fizeram tudo que estava ao alcance deles." (Méd. 13)

VALORIZAÇÃO DO CUIDADO ESTÉTICO evidencia que os profissionais não conservaram a idéia de que a tecnologia sofisticada deve ser empregada em todos os casos, dando valor à arte do cuidar. O cuidado estético ocorre quando o médico e a enfermeira movem-se da superfície da experiência para a compreensão do significado daquele momento único para o paciente e a família. Ao proporcionar a morte digna para a criança, o profissional percebe que a prioridade do cuidado nas situações de final de vida não é promover a cura, e sim oferecer o alívio do sofrimento para o paciente e a família.

"Acho que foi digno porque a criança aproveitou os últimos dias dela em uma boa condição, não morreu sofrendo, não só a criança, mas também para os pais, embora tivesse sofrido não teve só sofrimento." (Méd. 10)

"Tive outra experiência de uma criança terminal que eu queria cuidar dela, passar um hidratante, trocar a fixação do tubo, até para melhorar a aparência para a família que está ali estressada. Então, fiz tudo, higiene oral, um monte de coisa, trocar fralda... às vezes, o pessoal olha e diz: 'Por que você está fazendo tudo isso?'. A criança faleceu, mas, ao mesmo tempo, eu fiquei tranqüila, porque fiz o que eu tinha que fazer." (Enf. 8)

A síntese dos dados da Fase de Campo encontra-se no Diagrama dos Resultados - Fase de Campo apresentado a seguir, destacando-se os antecedentes, atributos e conseqüências da morte digna da criança na UTI pediátrica. 


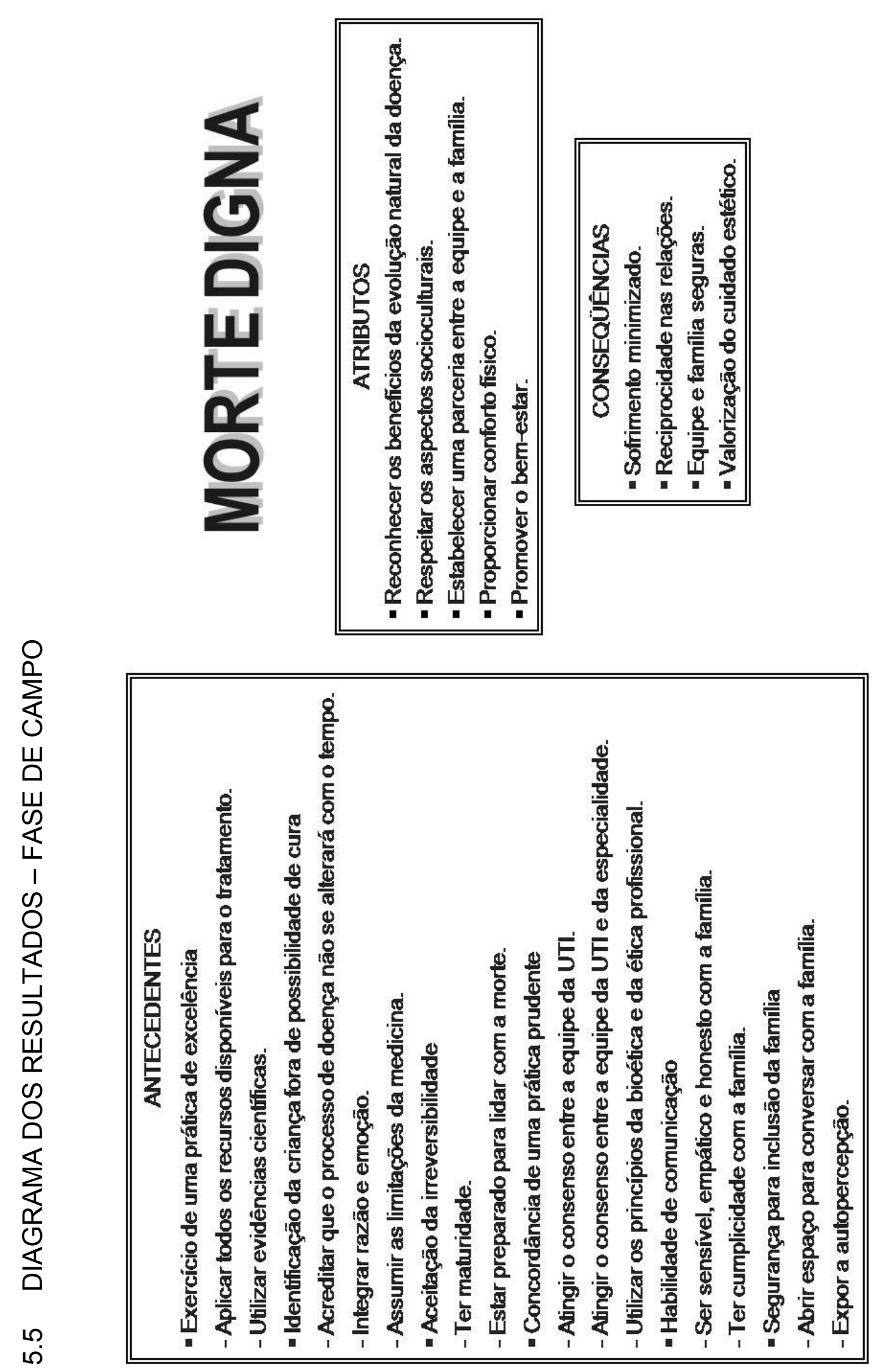




\section{FASE ANALÍTICA FINAL}

“... o real não está na saída nem na chegada: ele se dispõe para a gente é no meio da travessia." 
A última fase inclui a interface entre a Fase Teórica e os dados provenientes da Fase de Campo e a redação dos resultados (SchwartzBarcott, Kim, 2000). Nesta etapa, de acordo com a metodologia do Modelo Híbrido de Desenvolvimento de Conceitos, todas as manifestações do conceito devem ser verificadas, fazendo-se comparações, buscando variações dos dados obtidos nas experiências dos participantes. Assim, esta Fase busca sintetizar os dados empíricos e teóricos visando finalizar a definição do conceito e seus indicadores. Pode-se dizer que esta Fase encerra a análise dos dados.

A interface entre os antecedentes, atributos e conseqüências das Fases Teórica e de Campo, é apresentada no Diagrama Fase Analítica Final (página 103), onde são destacadas as similaridades encontradas em ambas. A seguir, tais similaridades serão discutidas, bem como as diferenças ou divergências encontradas nas duas Fases.

Os resultados da Fase Teórica evidenciam que a morte digna inicia-se com o reconhecimento do quadro irreversível da criança $(1,2,4,8,10$, $13,14,16,18,19,20,21,22,23,24,25,26,27,29,30,31,32,33,35,36$, $38,39,40,41,42,44,46,47,48)$. No entanto, o processo pelo qual isso ocorre não está claro nos dados da Fase Teórica. Na Fase de Campo, os dados mostram que para que o profissional possa identificar a criança fora de possibilidade de cura, ele precisa ter exercido uma prática de excelência. Neste sentido, o exercício de uma prática de excelência situação em que os profissionais têm a possibilidade de aplicar todos os recursos disponíveis para o tratamento da criança e utilizar as evidências científicas para avaliar a resposta da criança à terapêutica proposta - é o primeiro antecedente da morte digna. Isso quer dizer que para que o profissional tenha condições de determinar a irreversibilidade da doença, ele precisa ter exercido uma prática de excelência.

Os dados da Fase de Campo indicam que a identificação da criança fora de possibilidade de cura ocorre quando o médico acredita que o processo da doença não se alterará com o tempo. Para que isso ocorra, o 
profissional precisa integrar razão e emoção, a fim de avaliar a condição da criança e assumir as limitações da medicina.

A determinação da criança fora de possibilidade de cura baseia-se, normalmente, em critérios objetivos (por exemplo, uma metástase cerebral inoperável junto ao tronco cerebral); em critérios subjetivos (ausência de resposta ao tratamento) e em critérios intuitivos (experiência prévia com casos semelhantes) (Lago, Devictor, Piva, Bergounioux, 2007).

No entanto, nossos dados apontam um aspecto além desses apresentados pelos referidos autores, pois a percepção de que o tratamento acarreta aumento do sofrimento para a criança e a família evidencia um componente emocional na identificação da criança fora de possibilidade de cura. Embora a medicina seja considerada uma ciência essencialmente objetiva, não há como suprimir os componentes subjetivo e emocional na atuação do profissional de saúde. Reconhecer que esses componentes existem e atuam na prática clínica permite ao profissional refletir sobre seus próprios valores e crenças que influem nas decisões de final de vida.

Além disso, os dados da Fase de Campo apontam que a aceitação da irreversibilidade é outro antecedente da morte digna. Para que o profissional possa aceitar a morte da criança, ele precisa ter maturidade e estar preparado para lidar com a morte. Os dados da Fase Teórica indicam que o preparo profissional $(6,7,14,17,18,19,20,24,25,27,30$, $33,34,38,42,44,47,49)$ para trabalhar com a criança e a família no final de vida é um dos antecedentes da morte digna.

Porém, os dados da Fase de Campo evidenciam que, além do preparo profissional, é imprescindível que ele tenha maturidade para lidar com a morte. Esta maturidade refere-se ao conhecimento pessoal ou experiencial quanto ao limite de investimento terapêutico, bem como maturidade para aceitar a morte como um possível desfecho nas situações em que a criança não responde à terapêutica curativa.

Por outro lado, os dados da Fase de Campo apontam que quando o profissional encara a morte da criança como a interrupção precoce da vida, ele tem dificuldade na aceitação da irreversibilidade. Neste sentido, no 
entender de vários autores (Althabe et al., 2003; Casanueva Mateos et al., 2005; Carter et al., 2004; Carvalho et al., 2001; Duncan et al., 2007; Garros, 2003; Hinds et al., 2005; Hongo et al., 1995; Lago, Devictor, Piva, Bergounioux, 2007; Lago, Garros, Piva, 2007; Levetown et al., 1994; Matthews et al., 2006; McCallum et al., 2000; Meert et al., 2005; Robinson et al., 2006; Rotta, 2005), a identificação da criança fora de possibilidade de cura é particularmente difícil em pediatria.

Ao se considerar que a mortalidade em Unidade de Terapia Intensiva pediátrica oscila entre $5 \%$ e $15 \%$, a grande maioria das crianças admitidas em uma UTI pediátrica tem grande expectativa de cura. Portanto, o senso dominante na equipe assistencial, independente da gravidade do quadro, é adotar medidas visando salvar a vida da criança (Althabe, 1999; Althabe et al., 2003; Bracegirdle, 1994; Casanueva Mateos et al., 2005; Carter et al., 2004; Lago et al., 2005; Lago, Devictor, Piva, Bergounioux, 2007; Longden et al., 2007; McCallum et al., 2000; Tonelli et al., 2005; Wolfe et al., 2000).

Esses dados sugerem que a aceitação da irreversibilidade é uma situação particularmente difícil em pediatria, devido à alta expectativa de recuperação da criança e possibilidade de sobrevivência sem seqüelas graves.

Um outro antecedente encontrado na Fase Teórica e apontado pelos profissionais na Fase de Campo diz respeito ao tempo para que os pais possam aceitar a condição irreversível da criança e tomar decisões (2, $11,18,19,28,31)$. Para os profissionais, a família também tem dificuldade para aceitar a morte por se tratar de uma criança. Assim, o profissional percebe que a família precisa de tempo para assimilar a condição clínica irreversível para que ela possa aceitar a morte da criança.

Outro antecedente evidenciado tanto na Fase Teórica quanto na de Campo diz respeito à concordância de uma prática prudente. Vários autores colocam que, para que seja possível proporcionar a morte digna para a criança, é preciso: obter o consenso entre a equipe médica sobre as condutas de final de vida (equipe titular/especialidade com a equipe da UTIp) $(2,8,16$, $24,28,32,39,40)$ e participação da equipe multidisciplinar nas decisões quanto às condutas no final de vida $(1,2,3,4,13,18,19,25,30,32,39,40)$. 
Entretanto, os dados da Fase Teórica não evidenciam o processo transcorrido pelos profissionais envolvidos nos cuidados à criança até que se chegue a um consenso quanto à interrupção do investimento terapêutico. Os dados da Fase de Campo mostram que a concordância de uma prática prudente passa primeiro pelo consenso entre os médicos que atuam na UTI quanto à interrupção do tratamento curativo. Este consenso não é visto pelos profissionais como problemático, pois geralmente a equipe médica da UTI compartilha da impossibilidade de cura da criança por acompanhá-la continuamente, tendo a oportunidade de perceber a inefetividade do tratamento proposto com mais segurança.

Contudo, o consenso entre a equipe médica da UTI e da especialidade (equipes da oncologia, cardiologia, nefrologia etc.) é um processo mais árduo e que demanda um tempo maior, pois as várias percepções sobre as possibilidades de recuperação ou não da criança precisam ser consideradas, discutidas e analisadas, para que seja possível chegar a um consenso quanto à interrupção do investimento terapêutico. Nossos dados apontam que enquanto não se chega a um consenso entre a equipe médica da UTI e da especialidade, a criança continua sendo submetida aos variados procedimentos terapêuticos que vinham sendo empregados até o momento.

Este dado leva a pensar que, em muitas situações, a criança continua sendo submetida a todos os recursos diagnósticos e terapêuticos até que a morte ocorra. Embora os médicos intensivistas apontem que eles se permitem restringir alguns procedimentos diagnósticos e terapêuticos dolorosos, que não mudariam a evolução da doença, a não-obtenção do consenso entre a equipe médica da UTI e da especialidade leva os médicos intensivistas a não se sentirem autorizados para limitar o tratamento curativo e instituir cuidados e intervenções direcionadas para o alívio do sofrimento.

Nesta discussão, nota-se uma despreocupação com o envolvimento da família nas decisões. Com relação à participação da equipe multidisciplinar nas decisões de final de vida, embora os dados da Fase 
Teórica indiquem a importância da participação de todos os profissionais envolvidos nos cuidados à criança nas decisões, os dados da Fase de Campo indicam que isso não ocorre com freqüência na prática clínica. As decisões de final de vida ainda são centralizadas na figura do médico, seja ele da especialidade ou da UTI, tendo pouco envolvimento dos profissionais não-médicos nas decisões. De acordo com os próprios médicos, isso se deve à formação do profissional médico, ou seja, consideram que a prepotência do médico deve-se ao fato de ele considerar que faz atividades superiores àquelas executadas pelos outros membros da equipe multidisciplinar, tomando para si a incumbência de tomar decisões.

Para as enfermeiras, essa situação provoca desconforto, especialmente nas situações em que ela considera que $o$ investimento terapêutico é desmedido e provoca aumento do sofrimento para a criança e a família. Embora a enfermeira procure questionar a conduta do médico quando não concorda com a manutenção do investimento terapêutico, reconhece que a decisão final é do médico. Ela acredita que deve acatar a decisão médica passivamente. Nota-se uma lacuna entre os dados provenientes da literatura e os da Fase de Campo com relação à participação da enfermeira nas decisões de final de vida.

Para Bracegirdle (1994), quando a enfermeira não está envolvida ativamente no processo de tomada de decisão, pode questionar a interrupção do tratamento curativo, razão pela qual, ela deve estar completamente envolvida no processo de tomada de decisão.

Além disso, a autora ressalta que a visão dos pais e/ou da criança pode ser revelada, em primeira instância, para as enfermeiras, que devem advogar pela preservação da autonomia da criança e da família (Bracegirdle, 1994). Nesbit et al. (1997) ressaltam que a enfermeira tem a oportunidade de desenvolver um relacionamento de confiança com a família pela sua proximidade com a criança e a família durante as atividades de cuidado. Neste contexto, Freyer et al. (2006) acrescentam que, devido ao estabelecimento de vínculo entre a enfermeira e o paciente/família, a enfermeira está em uma posição privilegiada para defender os interesses da criança e da família. 
Porém, para que a enfermeira assuma uma postura mais ativa no processo de tomada de decisão quanto às condutas de final de vida, ela precisa acreditar que a sua participação é fundamental para que os interesses da criança e da família sejam preservados.

Os dados da Fase Teórica mostram a importância da utilização dos princípios bioéticos nas tomadas de decisão $(3,8,11,13,17,18,19,22,26$, 29, 30,31), bem como consulta à Comissão de Bioética nas situações dilemáticas $(1,4,8,17,18,19,24,26,27,39)$. Na Fase de Campo, torna-se evidente que os profissionais utilizam, fundamentalmente, os princípios bioéticos da beneficência e não-maleficência para deliberação nas situações de final de vida. Os princípios da autonomia e justiça foram pouco mencionados no processo de tomada de decisão. Os profissionais apontam, ainda, que a Comissão de Bioética não é freqüentemente acionada, sendo solicitada a intervir somente nas situações em que a equipe da UTI e a da especialidade responsável pela criança enfrentam conflitos intensos com a família.

Com relação à comunicação entre equipe, criança e família, os dados da Fase Teórica apontam para a necessidade do estabelecimento de uma comunicação clara e efetiva entre a equipe, criança e família $(6,7$, $9,10,11,12,14,15,16,18,19,20,21,24,25,26,28,30,33,34,35,38,40$, $41,43)$, bem como de informações precisas, honestas e congruentes para capacitar a família para tomar decisões $(2,6,7,10,11,12,15,16$, $17,18,23,28,39,41,43,47)$.

Para os médicos e as enfermeiras, a habilidade de comunicação depende tanto de uma postura sensível, empática e honesta com a família, como de desenvolver uma cumplicidade com a família. Para o profissional, a capacidade de ser sensível e empático com a família, tentando sentir ou imaginar a situação vivenciada por ela, o aproxima da experiência da família, facilitando o estabelecimento de uma comunicação efetiva. Além disso, os dados da Fase Teórica indicam a importância do estabelecimento de um relacionamento de confiança entre a equipe, família e criança $(3,7,11,14,15,18,20,26,28,30,33,35,39)$. Para os profissionais, a cumplicidade com a família, desenvolvida nas interações 
estabelecidas com a ela, permite uma proximidade da família, facilitando o diálogo entre a equipe e a família.

Além disso, um outro antecedente identificado na Fase de Campo refere-se à segurança para inclusão da família nas decisões de final de vida. Quando há concordância de uma prática prudente e o profissional tem habilidade de comunicação, ele se dispõe a abrir um espaço para conversar com a família sobre as condutas a serem tomadas frente ao quadro irreversível da criança; além disso, sente-se confortável para expor sua autopercepção sobre as condições da criança. Assim, o profissional coloca-se disponível para discutir e rediscutir com a família as condutas de final de vida quantas vezes forem necessárias, conforme identificado na Fase Teórica $(1,4,9,10,18,19,20,24,39,40)$.

Com relação ao trabalho em equipe multidisciplinar, vários autores colocam a importância de se ter uma equipe composta por médico, enfermeira, psicólogo e assistentes social e espiritual, para que seja possível proporcionar a morte digna para a criança $(7,10,14,20,21,25,30,31,33$, 34, 35, 38, 41, 43, 44, 49). Todavia, esse antecedente não foi evidenciado na Fase de Campo, os profissionais não apontaram o trabalho em equipe multidisciplinar como uma condição necessária para que se possa proporcionar a morte digna.

Vale ressaltar que a maioria dos trabalhos analisados $(71,4 \%)$ foi publicada em países da América do Norte e Europa, sobretudo nos Estados Unidos (42,8\%), onde o trabalho em equipe multidisciplinar é uma realidade na assistência à criança e à família no final de vida. No Brasil, a participação de profissionais como psicólogo e assistentes social e espiritual nas decisões e cuidados de final de vida ainda é incipiente, mesmo nas instituições terciárias, onde os cuidados de final de vida são conduzidos, geralmente, por médicos e enfermeiras. Esse fato pode justificar o porquê de este antecedente não constar no relato dos médicos e enfermeiras na Fase de Campo, por não vivenciarem efetivamente o trabalho em equipe multidisciplinar em sua prática profissional, considerando que a participação do psicólogo e dos assistentes social e espiritual não é condição necessária para que a morte digna aconteça. 
Quanto aos atributos, o primeiro deles evidenciado na Fase Teórica refere-se à limitação de suporte de vida nas situações de quadro clínico irreversível $(1,2,3,4,6,8,10,16,17,18,19,20,21,22,23,24,25,26,27$, $29,30,31,32,36,39,40,41,42,44,46,47)$. Este atributo corresponde ao reconhecimento dos benefícios da evolução natural da doença identificado na Fase de Campo. Para os profissionais, morrer dignamente é: não reanimar a criança em uma situação sabidamente irreversível; não introduzir uma terapêutica que não reverterá a situação; ou ainda limitar o tratamento que a criança está recebendo, por exemplo, diminuir a infusão de drogas vasoativas ou dos parâmetros da ventilação mecânica. Neste particular, os profissionais relacionam a morte digna à não-execução de ações que sustentam a vida da criança em uma situação sabidamente irreversível.

Nos estudos analisados na Fase Teórica, foram evidenciados dois atributos que se relacionam a respeitar os aspectos socioculturais, observado na Fase de Campo. São eles: respeito aos valores e crenças do paciente e da família $(3,7,8,11,13,16,18,19,20,22,24,28,30,33$, $35,41)$ e atendimento das necessidades religiosas/espirituais da criança e da família $(2,7,11,15,16,18,20,21,24,25,28,30,33,34,35$, $39,41,47)$.

Para os profissionais, é necessário compreender e respeitar as crenças, relações, interesses, comportamentos e valores espirituais, especialmente da família, com o intuito de estabelecer uma parceria com ela quanto aos cuidados e condutas de final de vida. Além disso, de acordo com a opinião dos profissionais, a família deve ser respeitada em sua prática religiosa ou espiritual, conforme evidenciado na Fase Teórica.

No que diz respeito à participação dos pais nos cuidados à criança $(3,28,34,41)$, os profissionais colocam que a percepção dos pais deve ser considerada no planejamento dos cuidados de final de vida, pois eles percebem que as expectativas e demandas da família podem ser diferentes do que a equipe supõe que seja o ideal. Os pais podem ou não participar dos cuidados à criança, dependendo de como eles se sentem em relação a isso. Quando os pais se sentem seguros e/ou à vontade para cuidar da 
criança, os profissionais consideram que isso deve ser estimulado, caso contrário, a equipe deve fornecer a assistência que a criança precisa.

Com relação à participação da família nas decisões de final de vida $(1,2,3,4,7,8,10,11,13,14,16,17,18,19,20,21,22,23,24,25,26$, $27,29,30,31,32,38,39,40,41,44,46,47,48)$, os dados da Fase de Campo evidenciam que os profissionais buscam estabelecer uma parceria entre a equipe e a família quanto à interrupção do tratamento curativo, respeitando o posicionamento da família.

Quanto à participação da criança nas decisões $(3,14,18,20,25$, $31,33,36,38,39,42,44,46,48)$, esse atributo não foi observado nos dados da Fase de Campo, ou seja, os profissionais não mencionaram a possibilidade de a criança participar das decisões quanto à interrupção ou não do tratamento curativo, bem como no planejamento dos cuidados de final de vida.

É importante ressaltar, ainda, que nem todos os trabalhos analisados na Fase Teórica eram da área de terapia intensiva pediátrica, pois o foco da Fase Teórica era explorar a morte digna da criança em todos os contextos em que havia a manifestação do conceito. Em decorrência disso, vários trabalhos analisados eram da área de oncologia $(10,2 \%)$, onde a participação da criança é observada com mais freqüência, devido ao tempo que se dispõe entre o diagnóstico e o fim da vida em crianças nessas situações, possibilitando que ela seja integrada no processo de tomada de decisão.

Um outro aspecto que merece ser ressaltado é que muitos trabalhos incluem os adolescentes na população pediátrica, ou seja, nessa faixa etária, o indivíduo tem maturidade nos desenvolvimentos cognitivo e emocional, o que permite a participação nas decisões. Mas nos relatos dos médicos e enfermeiras durante a Fase de Campo, observou-se que eles se referiam à criança em uma faixa etária em que as limitações cognitiva e emocional, próprias do desenvolvimento infantil, a restringia de participar das decisões.

Outros atributos evidenciados na Fase Teórica são: transição do foco dos cuidados curativos para os paliativos nas situações de quadro clínico irreversível $(2,6,8,10,14,16,17,18,20,21,24,25,30,33,34,35$, 
38 , 39, 41, 44, 48, 49); avaliação e tratamento da dor $(2,6,7,9,10,11,12$, $14,16,18,19,20,21,23,24,28,30,33,34,35,36,38,39,40,41,48,49)$ e avaliação e tratamento dos sintomas de desconforto $(2,6,9,10,11,12$, $14,18,19,20,21,23,24,25,28,30,33,34,36,38,39,40,41,49)$.

Estes atributos estão relacionados a proporcionar conforto físico e promover o bem-estar, verificados na Fase de Campo. Os profissionais percebem a importância da mudança do foco curativo para a promoção do conforto e bem-estar nas situações de final de vida, embora considerem principalmente o alívio da dor e do desconforto físico e o bem-estar da criança.

Segundo a Organização Mundial da Saúde (World Health Organization, 1990), os cuidados paliativos referem-se ao

[...] cuidado ativo total de pacientes cuja doença não responde mais ao tratamento curativo. Controle da dor e de outros sintomas e problemas de ordem psicológica, social e espiritual são prioritários. O objetivo dos cuidados paliativos é proporcionar a melhor qualidade de vida para os pacientes e seus familiares.

Durante a Fase de Campo, as demandas da família não foram apontadas pelos profissionais como um dos aspectos que devem compor os cuidados de final de vida. Por atuarem em um contexto altamente tecnológico, tendo como principal objetivo recuperar a saúde da criança, os profissionais têm como prioridade o cuidado à criança, sendo esta a filosofia que direciona as suas ações. Considerar uma abordagem mais abrangente, que contemple também as necessidades da família ainda é um desafio para os profissionais que atuam no contexto da UTI pediátrica. Contudo, observamos um movimento no sentido de incorporar as necessidades da criança e da família, saindo de uma abordagem centrada somente na patologia, para um olhar mais ampliado, que contemple as demandas da criança e da família.

Assim, percebe-se que os profissionais procuram proporcionar 0 atendimento das necessidades emocionais e sociais da criança $(7,10$, $11,14,18,20,21,23,24,25,33,34,38,39,41,42,43)$; entretanto, o atendimento das necessidades da família $(2,3,6,7,10,11,14,15,16$, 
$18,20,21,24,25,28,30,33,34,38,41,43,47)$ não é mencionado no planejamento dos cuidados à criança em final de vida. Em decorrência disso, o preparo da família para a morte da criança $(6,23,25,28,33,34,35,38$, $42,43,49)$ e a oportunidade para despedida $(2,6,7,9,11,18,19,23,24$, $28,29,30,31,41,42,47)$ não foram aspectos apontados pelos profissionais na Fase de Campo. A presença constante da família $(2,11,15,18,19,23$, $24,27,28,29,30,35,39,40,41,42)$ foi mencionada pelos profissionais como uma das ações no sentido de promover o bem-estar à criança, não como uma ação voltada para o atendimento das necessidades da família. Os autores ressaltam que tais ações constituem a morte digna, no entanto, para os profissionais, proporcionar o alívio do sofrimento para a criança é suficiente para que a família sinta-se confortada.

Outros atributos relacionados ao contexto foram evidenciados na Fase Teórica, tais como: ambiente apropriado e com privacidade (2, 8, $18,23,28,33,39,41,42,47)$; política de visitação flexível $(2,11,18,28$, $29,41,42,47)$ e oportunidade para a criança morrer em outro local que não a UTIp $(8,10,12,14,16,18,20,21,25,31,38,39,41,42,44,49)$.

Na Fase de Campo, os profissionais apontaram a importância de ter uma unidade de cuidados paliativos para atender as necessidades da criança e da família no final de vida, garantindo sua privacidade e conforto. Todavia, como isso ainda não é uma realidade no contexto brasileiro, as crianças continuam morrendo nas UTIs pediátricas. Também compartilhamos da idéia de que o ideal seria ter uma unidade especializada no atendimento da criança e da família no final de vida, mas na ausência desta, os profissionais que atuam na UTI pediátrica devem fornecer a assistência necessária não só para a criança, mas também para a família.

A realidade brasileira ainda está muito distante do que seria o ideal, ou seja, não há no Brasil unidades de cuidados paliativos suficientes para suprir a demanda de pacientes em final de vida, especialmente em pediatria. Então, o ideal fica muito distante do real. Vários autores corroboram o fato de que as crianças ainda continuam morrendo nas UTIs pediátricas (Althabe et al., 2003; Andresen et al., 2004; Carter et al., 2004; Garros, 2003; Hinds et 
al., 2005; Martino Alba et al., 2007; McCallum et al., 2000; Meert et al., 2007; Meyer et al., 2002; Ramnarayan et al., 2007; Salas Arrambide et al., 2005; Tagarro García et al., 2008; Tonelli et al., 2005; Torreão et al., 2004; Wolfe et al., 2000). Assim sendo, os profissionais que ali atuam precisam vencer o desafio de proporcionar a morte digna para a criança e a família, mesmo em um contexto considerado por eles adverso ou não favorável à promoção da morte digna.

Com relação às conseqüências da morte digna, durante a Fase Teórica, observou-se que minimizar/aliviar a dor e o sofrimento da criança $(2,6,7,8,9,10,12,13,16,18,19,20,21,23,24,25,27,28,30$, $31,32,33,34,36,39,40,41,44,46,47,49)$ e minimizar/aliviar o sofrimento da família $(2,3,6,7,8,9,15,28,30,31,33,39,41,42,47)$ são constantemente mencionadas pelos autores como resultado da morte digna da criança.

Essas conseqüências relacionam-se ao sofrimento minimizado apontado pelos profissionais durante a Fase de Campo. Para os eles, quando o sofrimento da criança e da família pôde ser minimizado, eles se sentem realizados com a assistência prestada e sabem que fizeram a contento o seu papel de assistir à criança e à família no final de vida. Melhor dizendo, proporcionar alívio ou minimização do sofrimento é importante não só para a criança e a família, como também para que o profissional sinta que cumpriu a sua meta com a própria atuação nos cuidados de final de vida.

Uma outra conseqüência evidenciada na Fase Teórica diz respeito à satisfação da família com os cuidados no final de vida $(2,7,11,12,16$, $23,24,25,28,31,40,41,43,47)$. Para os autores, quando a morte digna acontece, a família sente-se segura e satisfeita com os cuidados recebidos durante o período que antecede a morte da criança. Essa conseqüência relaciona-se à equipe e família seguras, identificada na Fase de Campo. Para os profissionais, é importante que a família e a equipe sintam-se seguras de que os melhores interesses da criança foram preservados, ou seja, embora tenha ocorrido a morte, ela recebeu todo o cuidado e 
assistência necessários durante todo o processo de doença. Quando a morte digna acontece, a equipe e a família não têm a sensação de que deixaram de fazer algo que pudesse mudar o curso natural da doença, sentindo-se tranqüilos de que a criança recebeu toda a assistência que precisava.

Algumas conseqüências foram evidenciadas somente na Fase Teórica, tais como: preservar a autonomia da criança e da família (11, 2 , $3,4,7,8,10,11,13,14,16,17,18,19,20,21,22,23,24,25,26,27,29,30$, $31,32,33,39,40,41,44,46)$; evitar a distanásia/futilidade terapêutica ( 3 , $22,24,26,27,29,30,32,36,39,40,47$ ); facilitar o processo de luto da família/melhorar a adaptação da família à perda $(2,6,7,10,11,15,16$, $18,20,23,24,25,28,30,33,38,41,42,43,45,48,49)$; ampliar as discussões sobre os cuidados no final de vida em pediatria $(6,8,27,30$, $32,34,39,42)$ e melhorar a qualidade dos cuidados no final de vida em pediatria $(9,12,14,16,17,20,21,24,25,27,34,38,39,40,41,43,44,47$, $48,49)$.

Com relação à preservação da autonomia da criança e da família, essa conseqüência aparece com muito destaque na literatura, especialmente devido à maioria de os trabalhos analisados ser produzida em países desenvolvidos, principalmente nos Estados Unidos, onde cada vez mais se busca a participação ativa de pacientes e familiares nas decisões quanto às condutas a serem tomadas, particularmente nas situações de final de vida.

Nos países em desenvolvimento, em especial no Brasil, observa-se que a medicina ainda tem um forte componente paternalista, sendo que os profissionais de saúde, principalmente o médico, assumem as decisões que deveriam ser compartilhadas com o paciente e/ou familiares. Embora várias publicações apontem para a importância de serem estimuladas posturas mais autônomas do paciente e da família frente às decisões de final de vida, nossos dados apontam que esse aspecto ainda não é uma realidade para os médicos e enfermeiras que atuam em UTI pediátrica no contexto brasileiro. 
Evitar a distanásia/futilidade terapêutica é outra conseqüência evidenciada na Fase Teórica, porém, esse aspecto não apareceu como conseqüência nos dados da Fase de Campo. Apesar da ampliação das discussões e das publicações sobre os aspectos bioéticos que envolvem a morte e os cuidados no final de vida a partir da década de 1990, percebe-se que os profissionais que atuam na UTI pediátrica ainda não relacionam os dados produzidos na literatura com a sua prática clínica.

Facilitar o processo de luto da família/melhorar a adaptação da família à perda também não foi evidenciada como conseqüência nos dados da Fase de Campo. Para Meert et al. (2000), o cuidado à criança e à família durante o processo de morrer tem uma profunda influência na maneira que a família lidará com a perda. Porém, os dados da Fase de Campo revelam que os profissionais não parecem sensibilizados para o favorecimento da adaptação da família à perda quando proporcionam a morte digna para a criança.

Por fim, ampliar as discussões sobre os cuidados no final de vida e melhorar a qualidade dos cuidados no final de vida em pediatria foram outras conseqüências identificadas apenas na Fase Teórica. Isso leva a pensar que os profissionais estão preocupados principalmente em resolver as situações práticas do dia-a-dia, restando pouco tempo para refletir sobre um aspecto mais amplo do cuidado. Quando o profissional proporciona a morte digna, ele não está somente proporcionando a assistência necessária para aquela criança, mas também contribuindo para que os cuidados no final de vida em pediatria sejam continuamente refletidos e melhorados.

Além disso, evidenciamos duas conseqüências relacionadas ao aspecto interacional ou relacional do cuidado na Fase de Campo, que são: reciprocidade nas relações e valorização do cuidado estético. Se, por um lado, muitas vezes os profissionais agem movidos pela rotina tecnológica da UTI pediátrica, por outro, ao proporcionar a morte digna eles identificam como conseqüências tanto a reciprocidade nas relações, como a valorização do cuidado estético. Para os profissionais, a reciprocidade nas relações é a troca ocorrida entre a equipe e a família, por terem 
compartilhado a experiência de final de vida da criança, levando ao respeito e confiança mútuos entre a equipe e a família.

Com relação ao cuidado estético, os profissionais não conservam a idéia de que a tecnologia sofisticada deve ser empregada em todos os casos, dando valor à arte do cuidar, ou seja, quando o profissional promove a morte digna, ele identifica a necessidade de o cuidar se sobrepor à ideologia de cura, embora este ainda seja o paradigma dominante entre as equipes que atam na UTI pediátrica.

\subsection{DEFININDO A MORTE DIGNA NA UTI PEDIÁTRICA}

Ao refletirmos sobre o processo da construção do conceito de morte digna da criança na UTI pediátrica, pudemos observar que este conceito surge em um contexto em que se associa a morte a procedimentos tecnológicos desmedidos.

Os avanços tecnológicos propiciaram o diagnóstico e a cura de doenças que anteriormente eram consideradas irreversíveis. Com isso, houve uma tendência de empregar inúmeros recursos terapêuticos para tentar recuperar a saúde da criança, justificando o aumento significativo de mortes que atualmente ocorre nas UTIs pediátricas. Hoje, praticamente, não é concebível que uma criança morra sem ter sido submetida aos inúmeros recursos diagnósticos e terapêuticos disponíveis em uma UTI.

Com a melhoria no atendimento primário, a prevenção de doenças infectocontagiosas e o progresso nos cuidados de saúde pública, o número de pacientes internados em UTI pediátrica por doenças agudas diminuiu muito na última década. Neste contexto, a limitação de suporte de vida associa-se, notadamente, às doenças crônicas, pois, nesses casos, as crianças têm uma doença suficientemente conhecida, com um prognóstico de vida reservado. 
A limitação de suporte de vida abarca ordem de não reanimar, nãooferta e retirada de suporte vital. Essa conduta surgiu na prática da terapia intensiva com a finalidade de evitar tratamentos que só prolongariam a vida, sem alterar a evolução da doença, quase sempre levando a tratamentos fúteis, com agregação apenas de sofrimento.

Atualmente, há uma tendência crescente de limitação de suporte de vida, principalmente às custas de ordem de não reanimar, considerada um caminho intermediário entre a manutenção do tratamento curativo e a retirada das medidas de suporte de vida, assim como restrição/não-oferta de ventilação mecânica e/ou drogas inotrópicas. Isto significa que as crianças ainda estão recebendo tratamento agressivo até o momento da morte, indicando dificuldade de assumir decisões mais ativas quanto à limitação de suporte de vida, como a retirada de suporte vital.

A partir da década de 1990, vários estudos foram publicados questionando o paradigma da "vida a qualquer custo". Atualmente, há uma tendência de serem privilegiados a qualidade de vida e o alívio do sofrimento. Apesar da ampliação das discussões sobre os cuidados no final de vida a partir da década de 1990, culminando com a Resolução no 1.805/2006 do Conselho Federal de Medicina que postula (Brasil, 2006):

Na fase terminal de enfermidades graves e incuráveis é permitido ao médico limitar ou suspender procedimentos e tratamentos que prolonguem a vida do doente, garantindo-lhe os cuidados necessários para aliviar os sintomas que levam ao sofrimento [...].

Muitos profissionais ainda temem as conseqüências éticas/legais decorrentes da limitação de suporte de vida. Esse fato é evidenciado nos estudos que apontam o "registro telegráfico" dos eventos que antecedem o óbito nos prontuários dos pacientes.

Por outro lado, o encurtamento da vida como efeito não-intencional do tratamento da dor e sintomas de desconforto é aceitável do ponto de vista ético, justificando-se no duplo efeito das medicações.

Com relação à autonomia para a tomada de decisão, em muitas situações, a criança não tem competência para exercer o seu direito à 
autonomia devido ao limitado desenvolvimento cognitivo-emocional ou, ainda, por estarem sedadas e/ou inconscientes. Desta forma, os pais ou representantes legais assumem as decisões privilegiando os melhores interesses da criança. Isso não implica que a criança não deva participar das decisões quando possível, o que é até desejável.

De acordo com a Resolução acima citada (Brasil, 2006), deve-se “... respeitar a vontade do paciente ou de seu representante legal". Porém, as atitudes médicas paternalistas ainda predominam nos contextos pediátricos dos países latino-americanos, onde as decisões são tomadas de forma unilateral pela equipe médica e apenas informadas ao paciente e à família. Os profissionais de saúde, em especial os médicos, ainda têm dificuldade para o estímulo de posturas mais autônomas dos familiares nas decisões.

Recentemente, os cuidados intensivos e paliativos eram ainda considerados excludentes; hoje, cresce a tendência de incorporação da filosofia de cuidados paliativos nas UTIs pediátricas nas situações de final de vida, contemplando as necessidades do paciente e da família. Em algumas situações, seria benéfico que, diante de condição irreversível, houvesse oportunidade para que a criança fosse transferida para um local mais apropriado, como a sua casa ou um serviço especializado em cuidados paliativos pediátricos, porém, esses serviços ainda são escassos no contexto brasileiro.

Além disso, geralmente o assunto morte não é privilegiado na formação dos profissionais de saúde, que, basicamente, são preparados para "salvar vidas"; em decorrência disso, a morte é interpretada como fracasso; especialmente quando a morte envolve uma criança, esse assunto é menos discutido ainda, em virtude da expectativa de que a morte não aconteça nessa fase da vida. Com isso, os estudos relacionados aos cuidados no final de vida entre adultos são mais desenvolvidos. Por outro lado, cresce o interesse da comunidade pediátrica pelas questões de final de vida em um contexto onde se busca a dignidade no processo de morrer. 
A partir da integração dos dados das Fases Teórica e de Campo, foi possível produzir uma rica tentativa de definição do conceito de morte digna da criança na UTI pediátrica:

MORTE DIGNA na UTI pediátrica é ter um tratamento clínico de excelência no final de vida, com honra aos benefícios da evolução natural da doença, respeito aos aspectos socioculturais, conforto físico e bem-estar. A morte digna ocorre em um contexto de veracidade e parceria entre a equipe e a família, no qual é possível expressar expectativas e receios. O resultado da morte digna é o alívio do sofrimento tanto da criança quanto da família.

É importante ressaltar que a definição de um conceito é sempre dinâmica, isto é, ela é passível de alterações na medida em que o conceito é aplicado tanto nas pesquisas como na prática clínica. Fica aqui o desafio para pesquisadores e profissionais que atuam no cuidado à criança e à família nas situações de final de vida: aplicarem, refinarem e ampliarem o conceito de morte digna da criança na UTI pediátrica. 


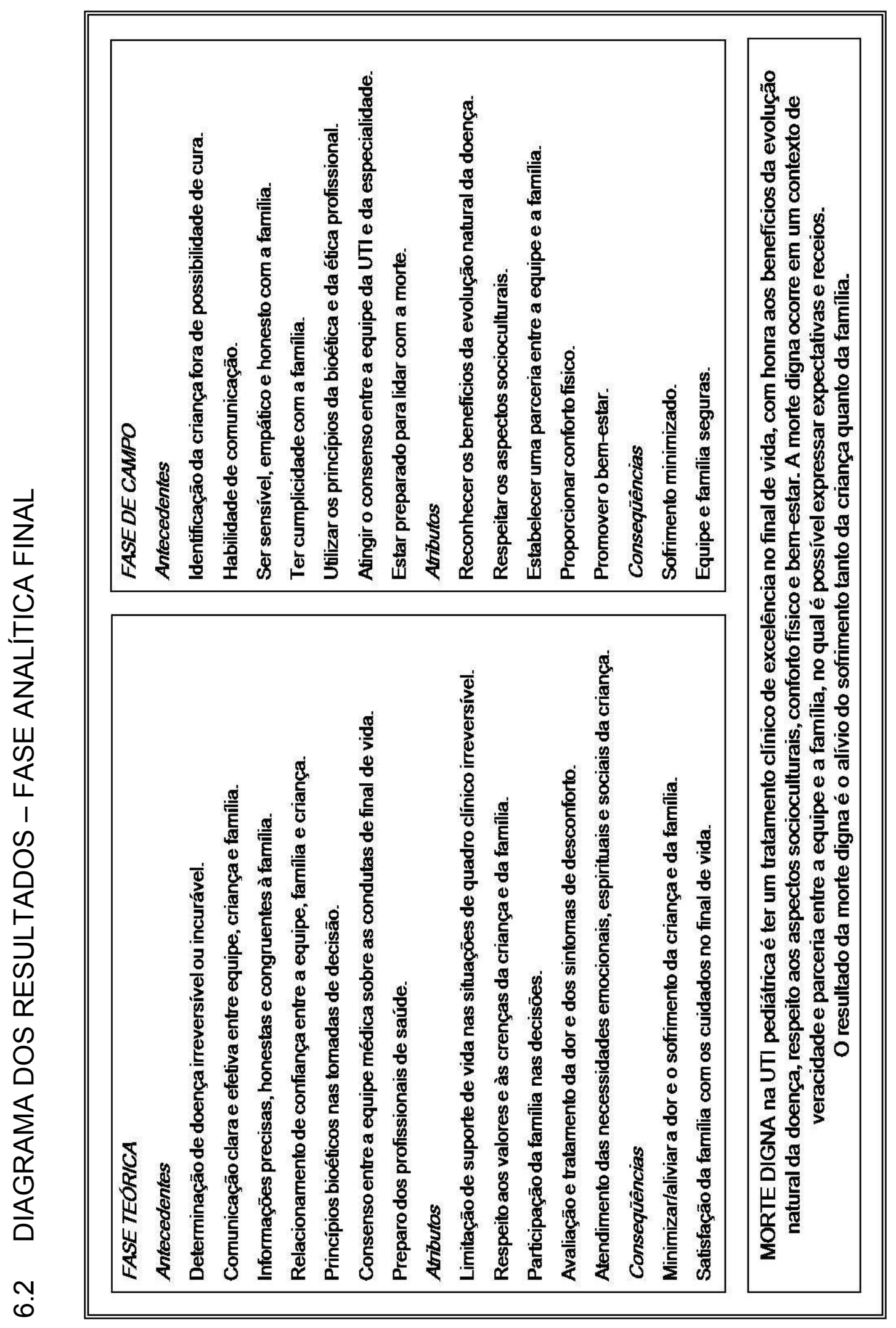




\section{CONSIDERAÇÕES FINAIS}

"Mas é doce morrer nesse mar de lembrar e nunca esquecer, se eu tivesse mais alma pra dar eu daria, isso pra mim é viver." 
A utilização do Modelo Híbrido de Desenvolvimento de Conceitos na presente pesquisa possibilitou a integração dos achados provenientes da literatura (Fase Teórica) com os dados da pesquisa de campo (Fase de Campo), permitindo uma compreensão apurada do conceito de morte digna da criança na UTI pediátrica.

$\mathrm{Na}$ Fase Teórica, foi possível identificar as lacunas existentes na literatura quanto à definição do conceito de morte digna na UTI pediátrica, levando a inconsistências nas proposições dos cuidados de final de vida para a criança e a família, devido ao déficit de uma linguagem comum entre os pesquisadores e profissionais que atuam na prática clínica. Foi possível identificar que a morte digna é fortemente influenciada pelo contexto em que ela ocorre, sendo, portanto, impossível fazer generalizações a partir dos achados de estudos desenvolvidos em outros contextos. É crescente o número de publicações sobre a morte digna no contexto da oncologia, o que permite refletir sobre os cuidados de final de vida, porém, sem a possibilidade de transpor os conhecimentos desta área para o contexto da UTI pediátrica.

Vale ressaltar a limitação da presente pesquisa no sentido de permitir generalizações, pois os dados da Fase de Campo foram obtidos através do depoimento de um número limitado de profissionais que atuam nos cuidados de final de vida no contexto da UTI pediátrica. Para que o conceito de morte digna da criança possa ser amplamente compreendido, futuros estudos deveriam ser desenvolvidos em outros cenários, como nas enfermarias, unidades de cuidados paliativos e nas situações de home care, entre outros. Além disso, destaca-se que este estudo constituiu o passo inicial na exploração do conceito de morte digna da criança na UTI pediátrica, outras pesquisas deveriam ser desenvolvidas a fim de aplicar, refinar e ampliar o conceito investigado.

Explorar a experiência dos médicos e enfermeiras, que são os profissionais responsáveis pelos cuidados à criança na UTI pediátrica, permitiu a identificação dos elementos experienciais que compõem o conceito de morte digna da criança. Assim, pôde-se compreender como se dá a manifestação do conceito na prática clínica, possibilitando a ampliação dos dados identificados na Fase Teórica. 
Neste particular, a pesquisa de campo acrescenta a compreensão dos valores e crenças que estão por trás das situações ou condutas protocolares identificadas na Fase Teórica. Isso viabiliza a reflexão sobre as atitudes dos profissionais, que não são motivadas exclusivamente pelos protocolos de condutas, mas também pelo significado que eles atribuem à situação vivenciada pela criança e família. Estes significados são construídos ao longo de sua vida e prática profissional, na medida em que o profissional entra em contato com as variadas situações e vai definindo e redefinindo a sua conduta frente à criança e à família.

Ao estudarmos a experiência da enfermeira no cuidado à criança e à família durante o processo de morrer (Poles, Bousso, 2006) foram identificados os fatores que contribuem para 0 afastamento e/ou aproximação das enfermeiras à família nesse contexto. As dificuldades e facilidades enfrentadas por elas durante este processo são pautadas nos significados atribuídos nas interações e visões de mundo que adquirem ao longo de sua vida e de sua prática profissional. Ao se depararem com a morte da criança, vivenciam uma trajetória em que a representação de precisar cumprir com seu papel profissional remete a atalhos e empecilhos que compõem o contexto desta experiência.

O presente estudo amplia a compreensão dos cuidados à criança e à família no final de vida, na medida em que explora o conceito de morte digna da criança na UTI pediátrica tanto na literatura, como na experiência dos profissionais que atuam no cuidado direto à criança e à família. Clarificar um conceito que, até então, permanecia no senso comum, permite fortalecer teorias sobre os cuidados no final de vida à criança e à família, bem como possibilita aos profissionais que atuam na prática clínica refletirem sobre as motivações que pautam atitudes e decisões diante da criança fora de possibilidade de cura.

Consideramos que a reflexão sobre a prática profissional e os valores e crenças que pautam as ações dos profissionais de saúde é uma estratégia importante para promover a morte digna da criança na UTI pediátrica. A reflexão permite fazer interconexões entre observações, 
experiências prévias e julgamentos, sendo imprescindível no processo de tomada de decisão, e também promove a significação e ressignificação da experiência, pois encoraja a reformulação de problemas e hipóteses ao olhar a situação através de múltiplas perspectivas. A reflexão é particularmente importante na área da medicina, pois a prática baseada em evidências requer que $\mathrm{o}$ profissional analise a melhor evidência, considerando seus próprios valores e hipóteses, ao mesmo tempo em que considera as crenças e os valores de cada paciente e família (Plack, Greenberg, 2005). Neste sentido, acreditamos que as entrevistas realizadas com médicos e enfermeiras que atuam em UTI pediátrica possibilitaram uma oportunidade para que os profissionais pudessem repensar e ressignificar sua prática profissional.

De acordo com Silva (2004), quando os profissionais têm a oportunidade de significar e/ou ressignificar suas ações diante do paciente em final de vida, é possível entender a diferença entre se comunicar com alguém que está morrendo e ser tecnicamente muito bom. Para a autora, o profissional precisa reconhecer que está partilhando um momento único na vida de qualquer ser humano e que a maneira de estar presente nesse momento poderá transformá-lo em algo menos sofrido e mais tranqüilo tanto para o paciente como para a família.

Com relação à experiência da família ao vivenciar a morte da criança na UTI pediátrica, Bousso e Angelo (2003) identificaram que a família vive a cisão definitiva desde o momento em que não pode mais ter esperança pela vida da criança. Este momento acontece quando a morte propriamente dita ocorre, como também quando a família recebe a notícia de que a criança não tem mais possibilidade de cura. Nesta situação, a família e os profissionais envolvidos nos cuidados à criança têm um desafio em comum: lidar com a realidade de que a criança morrerá, a despeito dos recursos empregados no sentido de promover a cura.

O presente estudo evidencia que aceitar a morte da criança não é um desafio que se coloca somente para a família, como apresentado por Bousso e Angelo (2003); o profissional também precisa aceitar que os seus 
esforços no sentido de restabelecer a saúde da criança não são capazes de recuperá-la. Essa aceitação o leva a direcionar a assistência, que, até então, era orientada para a cura, para a promoção do conforto e bem-estar da criança.

As autoras apontam que a vivência de angústia e sofrimento da família ao ver a criança sofrer faz com que ela aceite com resignação que o melhor é interromper o sofrimento. Elas ressaltam, ainda, que isso não significa que a família deseja a morte do filho, mas, simplesmente, que não pode aceitar que o filho continue em uma luta superior às condições de viver (Bousso, Angelo, 2003).

Foi possível identificar, no presente estudo, que os profissionais levam em consideração o sofrimento vivenciado pela criança e família quando tomam a decisão de interromper o tratamento curativo nas situações em que ele se mostra inefetivo.

Integrar os achados de estudos que se dedicaram a compreender a experiência da família com os resultados desta pesquisa permite ampliar as possibilidades para o cuidado da criança e da família nas situações de final de vida.

Em um artigo recente publicado na Pediatric Critical Care Medicine, Meert et al. (2008) estudaram como os pais de crianças que morreram na UTI pediátrica percebiam a comunicação das más notícias neste contexto. Os autores identificaram que os pais necessitam de informações honestas sobre as condições da criança e possibilidade de morte, para que não alimentem falsas expectativas com relação à recuperação da criança. Em nosso estudo, foi possível identificar que os profissionais precisam de um tempo para estabelecer uma relação de cumplicidade com a família, para que eles possam se sentir seguros para compartilhar com a família as condutas e decisões frente à impossibilidade de cura da criança.

Esse aspecto leva a refletir que a interação efetiva entre equipe e família depende do estabelecimento de um relacionamento de confiança, que permita a ambos sentirem-se à vontade para expressarem suas expectativas. Porém, para que esse relacionamento de confiança seja 
estabelecido, o profissional precisa de um tempo para conhecer a família e também ser conhecido por ela. Isso leva a pensar que nas situações agudas, em que rapidamente a criança evolui para a morte, os profissionais encontram um desafio ainda maior para estabelecer uma interação efetiva com a família e proporcionar a morte digna.

Um outro aspecto aqui relevante diz respeito à questão da ética profissional, que permeia as decisões de final de vida. Embora haja uma tentativa do Conselho Federal de Medicina de respaldar as ações dos médicos diante das situações de final de vida, através da Resolução $n^{\circ}$ 1.805/2006 (Brasil, 2006), ainda existe uma lacuna entre as diretrizes da prática médica e a legislação vigente no Brasil.

Para Farah (2008), a morte digna pregada na Resolução $\mathrm{n}^{\circ}$ 1.805/2006 não é a morte antecipada, deliberadamente provocada, como na idéia atual de eutanásia, mas sim a morte mais natural e humana, quando já não se pode mais evitar ou adiar a sua ocorrência. Para o autor, na morte digna, não se corta um processo de vida, pois o paciente já se acha inserido em irreparável processo de morrer, que somente pode ser precariamente adiado, mas não contido. O autor ressalta, ainda, que se submeter à tecnologia não pode ser obrigação legal, até porque ela sequer é disponibilizada a todas as pessoas que dela necessitam. Assim, a citada Resolução representa a possibilidade de recusa ao abuso de recursos técnico-científicos que, na visão do autor, não podem ser obrigatórios.

Por outro lado, para Junqueira (2008), a Resolução $n^{\circ} 1.805 / 2006$ é nula por tratar de tema manifestadamente ilegal, com efeitos discutíveis e limitados no campo da responsabilidade médica. Além do mais, destaca que os médicos e as demais pessoas que agirem em conformidade com a citada Resolução não estarão isentos das responsabilidades civil e criminal oriundas de seus atos. Para o autor, a Resolução CFM n 1.805/2006 revogou tacitamente alguns artigos do Código de Ética do Médico (Resolução CFM n 1.246/1988). Um deles é o Art. 66 que proíbe o médico de "utilizar, em qualquer caso, meios destinados a abreviar a vida do paciente, ainda que a pedido deste ou de seu responsável legal". Outro 
artigo revogado seria o Art. 42 que impede o médico de "praticar ou indicar atos médicos proibidos pela legislação do país". Além disso, o autor considera que o Conselho Federal de Medicina também revogou o Art. 55 do Código de Ética que proíbe o médico de "usar da profissão para corromper os costumes, cometer ou favorecer crime" (Junqueira, 2008).

De acordo com Junqueira (2008), a limitação ou retirada das medidas de suporte de vida é procedimento vedado e criminalizado pela legislação brasileira. Para o autor,

[...] com a referida Resolução, o Conselho Federal de Medicina deixa de respeitar o princípio ético de qualquer profissão que é o de obedecer as leis de seu país tentando por meio de resolução limitar o preceito da inviolabilidade do direito à vida, fundamentado no Art. $5^{\circ}$ caput da Constituição do Brasil.

De acordo com o autor, a Resolução CFM n 1.805/2006 tenta justificar o ato ilegal de deixar o paciente morrer. Nesta perspectiva, os médicos que apoiarem sua prática na referida Resolução não seriam penalizados pelo conselho profissional, mas processados civil e criminalmente. Junqueira (2008) destaca, ainda, que uma resolução do Conselho Federal de Medicina jamais terá o status hierárquico normativo do Código Penal Brasileiro.

Um outro aspecto que deve ser considerado nas decisões de final de vida refere-se à autonomia do paciente. Quando o paciente encontra-se lúcido, gozando plenamente de suas capacidades mentais, tem-se a tendência de aceitar com a mais tranqüilidade a sua decisão, privilegiando e garantindo o seu direito à autonomia. No caso de crianças, que geralmente possuem limitação emocional e cognitiva, próprias de seu processo de desenvolvimento, geralmente os pais assumem o direito de decidir, mas, por outro lado, aparece o questionamento sobre o componente da autodeterminação, que não pode ser exercida legalmente pela criança. Acrescido a isso, soma-se o fato de maior expectativa de cura e possibilidade de uma vida futura para a criança. Isso torna as decisões de final de vida ainda mais problemáticas e repletas de dilemas quando se trata de uma criança. 
Neste sentido, a inconsistência de posicionamentos entre juristas e médicos, representados pelo Conselho Federal de Medicina, leva os profissionais que atuam na prática clínica a se sentirem desamparados legalmente diante de terem de decidir pela manutenção de uma condição de vida artificial, conforme evidenciado no presente estudo.

Por outro lado, atualmente, a ciência médica, com seu notável progresso científico, permite diagnosticar, com grande certeza, a irreversibilidade de uma doença. É importante salientar que tal segurança médica não existia em 1940, data da elaboração do Código Penal. No entanto, hoje ainda persiste a repressão de medidas que promovem a morte sem sofrimento, ainda que autorizada por familiares. O Código Penal pode ser considerado ultrapassado neste assunto.

Em várias ocasiões, comissões de juristas buscaram a alteração do Código Penal para regular, na área penal, a prática da limitação ou retirada das medidas que sustentam a vida. Os conflitos de opiniões impediram o estabelecimento de um consenso sobre as condutas de final de vida. Todavia, prevalece o princípio de que deve caber ao médico a interpretação e decisão em face da indevida obstinação terapêutica. Desta forma, esta deve ser uma decisão médica, observadas as cautelas próprias (Farah, 2008). Porém, é desejável que tanto o paciente/família quanto os outros membros da equipe de saúde participem democraticamente do processo de tomada de decisão.

Além disso, o prolongamento do sofrimento de pacientes sem possibilidades terapêuticas de cura encarece, quase sempre, as despesas médico-hospitalares, onerando o custo tanto do seguro-saúde quanto do Sistema Único de Saúde (SUS). A resolução parece inspirada na preocupação da humanização da medicina, que, como no Direito, não se compõe apenas de técnica e ciência.

Nos Estados Unidos, os custos para a manutenção da alta tecnologia nas UTIs são considerados excessivos; a diária de uma UTI americana gira em torno de 3 mil dólares (Luce, Rubenfeld, 2002). Contudo, na concepção 
de Zamperetti et al. (2008) a "... qualidade dos cuidados de final de vida...” não está relacionada à "... quantidade de recursos aplicados”.

Assim, na morte digna, busca-se a priorização da pessoa doente e não mais o tratamento da doença, atenuando a obsessão de sustentar sempre a vida biológica, levada à obstinação diagnóstica e terapêutica. Esta batalha torna-se fútil, porque, ao defender o direito sagrado à vida, equivale à negação da sua própria dignidade. A morte digna gira em torno do tema trágico da morte, mas com a grandeza de defender a dignidade humana (Farah, 2008).

De acordo com Zamperetti et al. (2008), a dignidade possui três dimensões: a primeira é universal, ou seja, refere-se ao valor do ser humano; a segunda refere-se às diferentes interpretações da dignidade, dependendo do contexto; a terceira diz respeito ao significado que cada paciente e família atribuem à dignidade. Assim, a dignidade é relativamente universal, pois depende de fatores culturais e pessoais, ou seja, não é possível estabelecer princípios universais para promover a dignidade do paciente no final de vida.

As decisões de final de vida são baseadas em premissas que podem ser diferentes, dependendo das circunstâncias, da cultura e das pessoas envolvidas no processo de tomada de decisão. É evidente que diferentes pessoas, ou a mesma pessoa em várias circunstâncias, possam tomar decisões também diferentes. Conseqüentemente, os julgamentos não podem se basear somente em protocolos de conduta, conforme sugerido pelos entrevistados. Assim, as decisões de final de vida devem ser baseadas no respeito mútuo, incluindo a visão de todas as pessoas envolvidas na situação, com o intuito de alcançar a melhor decisão possível para a situação. Isto não é apenas ciência. Por outro lado, a deliberação pode ser altamente falível, ou seja, não há uma regra universal e objetiva para as decisões de final de vida, conforme evidenciado em nosso estudo.

Os dados aqui constantes mostram que as decisões de final de vida não se baseiam exclusivamente em critérios clínicos mensuráveis, mas também em critérios subjetivos ou pessoais, advindos das experiências 
vividas pelos profissionais ao longo de sua vida e prática profissional. Além disso, os profissionais apontam que cada criança e cada família têm necessidades específicas, de acordo com suas crenças e valores, que devem ser respeitados. Estes dados corroboram que a morte digna não pode ser considerada como um conceito universal, dissociado da pessoa que é cuidada e de quem está cuidando.

Em um estudo sobre a análise do conceito de cuidar com dignidade, Coventry (2006) evidenciou a comunicação e informações honestas como antecedentes do conceito estudado, conforme observado também em nossa pesquisa. Para a autora, a dignidade depende da perspectiva de cada indivíduo, o que leva a refletir sobre a importância de estudos futuros que se dediquem a explorar o conceito de morte digna na perspectiva das crianças, familiares e outros profissionais envolvidos nos cuidados de final de vida.

No que tange às políticas públicas para promover a morte digna, podese fazer uma aproximação com a publicação de 18 de outubro de 2006, em que o Ministério da Saúde ressalta que a rede pública de saúde deve oferecer internação domiciliar aos pacientes que precisam de cuidados especializados, mas que não necessitam da internação hospitalar. Este é o objetivo da Política Nacional de Internação Domiciliar, instituída no Sistema Único de Saúde (SUS) e lançada nesta data em Brasília (DF), pelo presidente da República e pelo ministro da saúde em exercício. A política garante qualidade na atenção a pacientes que precisam de cuidados mais complexos e diários, mas sem a necessidade de hospitalização (Brasil, 2008).

A estratégia está dentro das ações previstas especialmente para a saúde do idoso no Pacto pela Saúde, firmado neste ano entre o Ministério da Saúde e os conselhos estaduais e municipais. O Pacto é um consenso de diretrizes, metas e ações para a saúde no Brasil. Além dos idosos, devem ter prioridade no atendimento domiciliar os portadores de doenças crônicodegenerativas agudizadas e clinicamente estáveis, as pessoas que necessitam de cuidados paliativos (grifo nosso) e aquelas com incapacidade funcional provisória ou permanente, com internações prolongadas ou reinternações, que demandem atenção constante (Brasil, 2008). 
Cabe salientar que não há especificação de que somente pacientes adultos ou idosos poderão usufruir desse benefício, o que leva a pensar que as crianças poderiam também ser beneficiadas com esta medida, cujo objetivo é propiciar atendimento humanizado, permitindo maior autonomia aos pacientes e às famílias durante o tratamento. Com isso, a expectativa é permitir a otimização na utilização dos leitos hospitalares e reduzir o risco de intercorrências e infecções de pacientes em longas internações com cuidados de média complexidade (Brasil, 2008).

Isso nos leva a pensar que enquanto a morte digna não for tratada como prioridade tanto pelos profissionais de saúde que atuam no cuidado direto ao paciente e à família, como pelas pessoas responsáveis por implementar políticas públicas que a favoreçam, os pacientes continuarão a morrer no ambiente frio, impessoal e tecnológico de uma UTI. 
8 REFERÊNCIAS 
Althabe M. Consenso sobre recomendaciones acerca de la limitación del soporte vital en terapia intensiva. Arch Argent Pediatr. 1999;97(6):411-5.

Athabe M, Cardigni G, Vassallo JC, Allende D, Berrueta M, Codermatz M, et al. Dying in intensive care unit: collaborative multicenter study about forgoing life-sustaining treatment in Argentine pediatric intensive care units. Pediatr Crit Care Med. 2003;4(2):164-9.

Andresen EM, Seecharan GA, Toce SS. Provider perceptions of child deaths. Arch Pediatr Adolesc Med. 2004;158(5):430-5.

Bardin L. Análise de Conteúdo. Lisboa (Portugal): Edições 70; 2006.

Benica SW, Longo CB, Barnsteiner JH. Perceptions and significance of patient deaths for pediatric critical care nurses. Crit Care Nurse. 1992;12(3):72-5.

Blatt L. Working with families in reaching end-of-life decisions. Clin Nurse Spec. 1999;13(5):219-23.

Bousso RS, Angelo M. The family in the intensive care unit: Living the Possibility of Losing a Child. Journal of Family Nursing. 2003;9(2):212-21.

Bracegirdle KE. A time to die: withdrawal of paediatric intensive care. $\mathrm{Br} \mathrm{J}$ Nurs. 1994;3(10):513-7.

Brasil. Conselho Federal de Medicina. Resolução CFM no 1.246/88. Código de Ética Médica, de 8 de Janeiro de 1988.

Brasil. Conselho Federal de Medicina. Resolução CFM n 1.805/06. Diário Oficial da União, 28 de Novembro de 2006.

Brasil. Ministério da Justiça. CONANDA - Conselho Nacional dos Direitos da criança e do Adolescente. Direitos da Criança e do Adolescente Hospitalizados. Resolução no 41/95, publicada no Diário Oficial da União, Seção 1, de 17 de Outubro de 1995.

Brasil. Ministério da Saúde. Rede pública de saúde oferecerá internação domiciliar. Disponível em: < http://portal.saude.gov.br/portal/aplicacoes/noticias/noticias_detalhe.cfm?co_ seq_noticia $=28205>$. Acesso em: 16/09/2008 
Burns JP, Mitchell C, Outwater KM, Geller M, Griffith JL, Todres ID, et al. End-of-life in pediatric intensive care unit after forgoing of life-sustaining treatment. Crit Care Med. 2000;28(8):3060-6.

Carter BS, Howenstein M, Gilmer MJ, Throop P, France D, Whitlock JA. Circumstances surrounding the deaths of hospitalized children: opportunities for pediatric palliative care. Pediatrics. 2004;114(3):e361-6.

Carvalho PRA, Rocha TS, Santo AE, Lago P. Modos de morrer na UTI pediátrica de um hospital terciário. Rev Ass Med Brasil. 2001;47(4):325-31.

Casanueva Mateos LC, Ruiz LP, Sánchez DJI, Ramos Casado MV, Belda HS, Llorente de la Fuente $A$, et al. Cuidados al final de la vida en la unidad de cuidados intensivos pediátrica: revisión de la bibliografía. An Pediatr (Barc). 2005;63(2):152-9.

Conselho Nacional de Saúde. Resolução n. 196, de 10 de outubro de 1996. Diretrizes e normas regulamentadoras de pesquisas envolvendo seres humanos. Bioética. 1996;4(2Supl):15-25.

Coventry ML. Care with dignity: a concept analysis. J Gerontol Nurs. 2006;32(5):42-8

Davies B, Eng B. Factors influencing nurse care of children who are terminally ill: a selective review. Pediatr Nurs. 1993;19(1); 9-14.

Davies B, Clarke D, Connaughty S, Cook K, MacKenzie B, McCormick J, et al. Caring for dying children: nurses' experiences. Pediatr Nurs. 1996; 22(6):500-7.

Ditto PH, Danks JH, Smucker WD, Bookwala J, Coppola KM, Dresser R, et al. Advance directives as acts of communication: a randomized controlled trial. Arch Intern Med. 2001;161(3):421-30.

Duncan J, Spengler E, Wolfe J. Providing pediatric palliative care: PACT in action. MCN Am J Matern Child Nurs. 2007;32(5):279-87.

Esteban A, Gordo F, Solsona JF, Alía I, Caballero J, Bouza C, et al. Withdrawing and withholding life support in the intensive care unit: a Spanish prospective multicentre observational study. Intensive Care Med. 2001; 27(11): 1744-9. 
Farah, E. Ortotanásia - Longo tema e conflituoso debate. Disponível em: $<$ http://www.ambitojuridico.com.br/site/index.php?n_link=revista_artigos_leitura\&artigo_id=1902 $>$. Acesso em 16/09/2008.

Ferrand E, Robert R, Ingrand P, Lemaire F. Withdrawing and withholding life support in the intensive care units in France: a prospective survey. Lancet. 2001; 357(9249):9-14.

Freyer DR, Kuperberg A, Sterken DJ, Pastyrnak SL, Hudson D, Richards T. Multidisciplinary care of the dying adolescent. Child Adolesc Psychiatr Clin N Am. 2006;15(3):693-715.

Garros D. Uma "boa" morte em UTI pediátrica: isso é possível? J Pediatr. 2003;79(Supl2):S243-54.

Garros D, Cox PN, Barker GA. Dying after withdrawal/limitation of care in Pediatric Intensive Care Unit. Crit Care Med. 2000;28(Suppl 12):A217.

Garros D, Rosychuk RJ, Cox PN. Circumstances surrounding end-of-life in a pediatric intensive care unit. Pediatrics. 2003;112(5):371-9.

Glaser BG, Strauss AL. Time for dying. Chicago: Aldine Publishing Company; 1968.

Hendrickson K, McCorkle R. A dimensional analysis of the concept: good death of a child with cancer. J Pediatr Oncol Nurs. 2008.

Hinds PS, Schum L, Baker JN, Wolfe J. Key factors affecting dying children and their families. J Palliat Med. 2005;8(Suppl1):S70-8.

Hongo T, Fujii Y, Yajima S, Matsushita T, Ogawa N, Kinjo Y. Analysis of the circumstances of death of 56 children suffering from cancer: proposal for the development of terminal medicine in Japan. Acta Paediatr Jpn. 1995;37(5):604-9.

Hopkinson J, Hallett C. Good death? An exploration of newly qualified nurses' understanding of good death. Int J Palliat Nurs. 2002;8(11):532-9.

Horta MP. Eutanásia - problemas éticos da morte e do morrer. Bioética. 1999; 7(1):27-33. 
Hutchfield K. Family-centred care: a concept analysis. J Adv Nurs. 1999;29(5):1178-87.

Junqueira AL. Prolongamento da vida de pacientes terminais. In: Âmbito Jurídico, Rio Grande, 45, 30/09/2007 [Internet]. Disponível em:

$<$ http://www.ambito-

juridico.com.br/site/index.php?n_link=revista_artigos_leitura\&artigo_id=2235 $>$. Acesso em 03/05/2008.

Keenan SP, Busche KD, Chen LM, McCarthy L, Inman KJ, Sibbald WJ. A retrospective review of a large cohort of patients undergoing the process of withholding or withdrawal of life support. Crit Care Med. 1997; 25(8):1324-31.

Kipper DJ, Martin L, Fabbro L. Decisões médicas envolvendo o fim da vida o desafio de adequar as leis vigentes às exigências éticas. J Pediatr. 2000;76(6):403-6.

Kipper DJ, Piva JP, Garcia PC, Einloft PR, Bruno F, Lago P, et al. The medical practices and modes of death on pediatric intensive care units in southern Brazil. Pediatr Crit Care Med. 2005;6(3):258-63.

Knafl KAQ, Deatrick JA. Knowledge synthesis and concept development in nursing. In: Rodgers BL, Knafl KA eds. Concept development in nursing. 2nd ed. Philadelphia: Saunders Company; 2000. p. 39-54.

Lago PM, Piva JP, Kipper DJ, Garcia PCR, Pretto C, Giongo M, et al. Limitação de suporte de vida em três unidades de terapia intensiva pediátrica do sul do Brasil. J Pediatr. 2005;81(2):111-7.

Lago PM, Devictor D, Piva JP, Bergounioux J. End-of-life care in children: the Brazilian and the international perspectives. J Pediatr (Rio J). 2007;83(2 Suppl):S109-16.

Lago PM, Garros D, Piva JP. Terminalidade e condutas de final de vida em unidades de terapia intensiva pediátrica. Rev Bras Ter Intensiva. 2007;19(3):359-363.

Leichtentritt RD, Rettig KD. Family beliefs about end-of-life decisions: an interpersonal perspective. Death Stud. 2002;26(7):567-94.

Levetown M. "Deciding" to allow my child to die in the intensive care unit. Pediatr Crit Care Med. 2005;6(5):604-6. 
Levetown M, Pollack MM, Cuerdon TT, Ruttimann UE, Glover JJ. Limitations and withdrawals of medical intervention in pediatric critical care. JAMA. 1994;272(16):1271-5.

Longden JV, Mayer AP. Family involvement in end-of-life care in a paediatric intensive care unit. Nurs Crit Care. 2007;12(4):181-7.

Luce JM, Rubenfeld GD. Can health care costs be reduced by limiting intensive care at the end of life? Am J Respir Crit Care Med. 2002;165(6):750-4.

Martino Alba R, Casado Flores J, Ruiz Díaz MA. Actitudes y necesidades de los intensivistas pediátricos ante la muerte de sus pacientes. An Pediatr (Barc). 2007;66(4):351-6.

Matthews K, Gambles M, Ellershaw JE, Brook L, Williams M, Hodgson A, et al. Developing the Liverpool Care Pathway for the dying child. Paediatr Nurs. 2006;18(1):18-21.

McCallum DE, Byrne P, Bruera E. How children die in hospital. J Pain Symptom Manage. 2000;20(6):417-23.

Meert KL, Eggly S, Pollack M, Anand KJ, Zimmerman J, Carcillo J, et al. Parents' perspectives regarding a physician-parent conference after their child's death in the pediatric intensive care unit. $J$ Pediatr. 2007;151(1):50-5, 55.e1-2.

Meert KL, Eggly S, Pollack M, Anand KJ, Zimmerman J, Carcillo J, et al. Parents' perspectives on physician-parent communication near the time of a child's death in the pediatric intensive care unit. Pediatr Crit Care Med. 2008;9(1):2-7.

Meert KL, Thurston CS, Sarnaik AP. End-of-life decision-making and satisfaction with care: parental perspectives. Pediatr Crit Care Med. 2000;1(2):179-85.

Meert KL, Thurston CS, Briller SH. The spiritual needs of parents at the time of their child's death in the pediatric intensive care unit and during bereavement: a qualitative study. Pediatr Crit Care Med. 2005;6(4):420-7.

Meyer EC, Burns JP, Griffith JL, Truog RD. Parental perspectives on end-oflife in the pediatric intensive care unit. Crit Care Med. 2002;30(1):226-31. 
Moritz RD, Dantas A, Matos JD, Machado FO. O comportamento do médico intensivista brasileiro diante da decisão de recusar ou suspender um tratamento. RBTI. 2001; 13(1): 21-8.

Moritz RD, Nasar SM. A atitude dos profissionais de saúde diante da morte. RBTI. 2004;16(1):14-21.

Morse JM. Exploring the theoretical bases of nursing using advanced techniques of concept analysis. ANS Adv Nurs Science. 1995;17(3):31-46.

Morse JM. Exploring pragmatic utility: concept analysis by critically appraising the literature. In: Rodgers BL, Knafl KA eds. Concept development in nursing. 2nd ed. Philadelphia: Saunders Company; 2000. p. 333-52.

Morse J, Hupcey JE, Mitcham C, Lenz ER. Concept analysis in nursing research: a critical appraisal. Sch Inq Nurs Pract. 1996;10(3):253-77.

Mota JAC. Quando um tratamento torna-se fútil? Bioética. 1999;7(1):35-9.

Nesbit MJ, Hill M, Peterson N. A comprehensive pediatric bereavement program: the patterns of your life. Crit Care Nurs Q. 1997;20(2):48-62.

Öhlén J, Segesten K. The professional identity of the nurse: concept analysis and development. J Adv Nurs. 1998;28(4):720-7.

Ouslander JG, Tymchuk AJ, Rahbar B. Health care decisions among elderly long-term care residents and their potential proxies. Arch Intern Med. 1989;149(6):1367-72.

Padilha MICS, Silva AL, Borenstein MS. Os congressos brasileiros - pontes para a liberdade e transformação da enfermagem. Rev Latino-am Enfermagem. 2001;9(3):7-13.

Papadatou D, Bellali T, Papazoglou I, Petraki D. Greek nurses and physicians grief as a result of caring for children dying of cancer. Pediatr Nurs. 2002;28(4):345-53.

Papadatou D, Martinson IM, Chung PM. Caring for dying children: a comparative study of nurses' experiences in Greece and Hong Kong. Cancer Nurs. 2001;24(5):402-12. 
Pessini L, Barchifontaine CP. Problemas atuais de bioética. São Paulo: Loyola, 1994.

Pithan LH. A dignidade humana como fundamento jurídico das "ordens de não-reanimação". Porto Alegre: EDIPUCRS, 2004.

Plack MM, Greenberg L. The reflective practitioner: reaching for excellence in practice. Pediatrics. 2005;116(6):1546-52.

Poles K, Bousso RS. O interacionismo interpretativo como referencial metodológico para gerar evidências nas pesquisas em enfermagem. Rev Min Enf. 2004; 8(3):395-7.

Poles K, Bousso RS. Compartilhando o processo de morte com a família: a experiência da enfermeira na UTI pediátrica. Rev Latino-am Enfermagem. 2006;14(2):207-13.

Poles K, Bousso RS. Morrer com dignidade: um desafio atual. In: Incontri D, Santos FS. A arte de morrer: visões plurais. Bragança Paulista: Comenius; 2007.

Ramnarayan P, Craig F, Petros A, Pierce C. Characteristics of deaths occurring in hospitalised children: changing trends. J Med Ethics. 2007; 33(5):255-60.

Rashotte J, Fothergill-Bourbonnais F, Chamberlain M. Pediatric intensive care nurses and their grief experiences: a phenomenological study. Heart Lung. 1997;26(5):372-86.

Robinson MR, Thiel MM, Backus MM, Meyer EC. Matters of spirituality at the end of life in the pediatric intensive care unit. Pediatrics. 2006;118(3):e71929.

Rodgers BL. Concepts, analysis, and the development of nursing knowledge: the evolutionary cycle. J Adv Nurs. 1989;14(4):330-5.

Rodgers BL. Philosophical foundations of concept development. In: Rodgers BL, Knafl KA eds. Concept development in nursing. 2nd ed. Philadelphia: Saunders Company; 2000. p.7-37. 
Rodgers BL, Knafl KA. Introduction to concept development in nursing. In: Rodgers BL, Knafl KA eds. Concept development in nursing. 2nd ed.

Philadelphia: Saunders Company; 2000. p.1-6.

Rotta AT. Cuidados no final da vida em pediatria: muito mais do que uma luta contra a entropia. J Pediatr. 2005;81(2):93-5.

Salas Arrambide MS, Poc OG, Miravete JLM, Pérez-Yarza EG, Caro IA. El pediatra ante la muerte del niño: integración de los cuidados paliativos en la unidad de cuidados intensivos pediátricos. An Pediatr (Barc).

2005;62(5):450-7.

Schramm FR. Morte e finitude em nossa sociedade: implicações no ensino dos cuidados paliativos. Rev Bras Cancerol. 2002;48(1):17-20.

Schwartz-Barcott D, Kim HS. An expansion and elaboration of the Hybrid Model of Concept Development. In: Rodgers BL, Knafl KA eds. Concept development in nursing. 2nd ed. Philadelphia: Saunders Company; 2000. p.129-59.

Sharman M, Meert KL, Sarnaik AP. What influences parents' decisions to limit or withdraw life support? Pediatr Crit Care Med. 2005;6(5):513-8.

Silva MJP. Comunicação com o paciente fora de possibilidades terapêuticas: reflexões. In: Pessini L, Bertachini L. Humanização e cuidados paliativos. 2a ed. São Paulo: Edições Loyola; 2004. p. 263-73.

Simpson SM. Near death experience: a concept analysis as applied to nursing. J Adv Nurs. 2001;36(4):520-26.

Souza DC, Troster EJ, Carvalho WB, Shin SH, Cordeiro AMG.

Disponibilidade de unidades de terapia intensiva pediátrica e neonatal no município de São Paulo. J Pediatr. 2004;80(6):453-60.

Swigart V, Lidz C, Butterworth V, Arnold R. Letting go: family willingness to forgo life support. Heart Lung. 1996;25(6):483-94.

Tagarro García A, Dorao Martínez-Romillo P, Moraleda S, López P, Moreno $T$, San-José B, et al. Cuidados al final de la vida en una unidad de cuidados intensivos pediátricos: evaluación por parte del personal y de los padres. An Pediatr (Barc). 2008;68(4):346-52. 
Tilden VP, Tolle SW, Garland MJ, Nelson CA. Decisions about life-sustaining treatment: impact of physicians' behaviors on the family. Arch Intern Med. 1995;155(6):633-8.

Tonelli HAF, Henrique AF, Mota JAC, Oliveira JS. Perfil das condutas médicas que antecedem ao óbito de crianças em um hospital terciário. $J$ Pediatr. 2005;81(2):118-25.

Torreão LA, Reis AGAC, Troster EJ, Oselka G. Ressucitação cardiopulmonar: discrepância entre o procedimento de ressucitação e o registro no prontuário. J Pediatr. 2000;76(6):429-33.

Torreão LA, Pereira CR, Troster EJ. Ethical aspects in the management of the terminally ill patient in the pediatric intensive care unit. Rev Hosp Clin Fac Med S Paulo. 2004;59(1):3-9.

Vendramini SHF, Villa TCS, Cardozo Gonzáles RI, Monroe AA. Tuberculose no idoso: análise de conceito. Rev Latino-am Enfermagem. 2003;11(1):96-103.

Walters G. Is there such a thing as a good death? Palliat Med. 2004;18(5):404-8.

Weissman DE. Decision making at a time of crisis near the end-of-life. JAMA. 2004;292(14):1738-43.

Welch SB. Can the death of a child be good? J Pediatr Nurs. 2008;23(2):120-5.

Wolfe J, Grier HE, Klar N, Levin SB, Ellenbogen JM, Salem-Schatz S, et al. Symptoms and suffering at the end of life in children with cancer. $N$ Engl J Med. 2000;342(5):326-33.

World Health Organization. Expert Committee. Cancer, Pain Relief and Palliative Care. Genebra; 1990.

Zagonel IPS. Análise de conceito: um exercício intelectual em enfermagem. Cogitare Enferm. 1996;1(1):10-4.

Zamperetti N, Bellomo R, Ronco C. Bioethical aspects of end-of-life care. Eur J Anaesthesiol. 2008;Suppl.42(25):51-7. 
Zawistowski CA, DeVita MA. A descriptive study of children dying in the pediatric intensive care unit after withdrawal of life-sustaining treatment. Pediatr Crit Care Med. 2004;5(3):216-23. 
9 APÊNDICE

(2003 


\section{APÊNDICE 1 - Numeração dos artigos Fase Teórica}

1. Vernon DD, Dean JM, Timmons OD, Banner W Jr, Allen-Webb EM. Modes of death in the pediatric intensive care unit: withdrawal and limitation of supportive care. Crit Care Med. 1993;21(11):1798-802.

2. Anderson B, McCall E, Leversha A, Webster L. A review of children's dying in a paediatric intensive care unit. N Z Med J. 1994;107(985):345-7.

3. Bracegirdle KE. A time to die: withdrawal of paediatric intensive care. $\mathrm{Br} J$ Nurs. 1994;3(10):513-7.

4. Levetown M, Pollack MM, Cuerdon TT, Ruttimann UE, Glover JJ. Limitations and withdrawals of medical intervention in pediatric critical care. JAMA. 1994;272(16):1271-5.

5. Hongo T, Fujii Y, Yajima S, Matsushita T, Ogawa N, Kinjo Y. Analysis of the circumstances of death of 56 children suffering from cancer: proposal for the development of terminal medicine in Japan. Acta Paediatr Jpn. 1995;37(5):604-9.

6. Charlton R. Medical education-addressing the needs of the dying child. Palliat Med. 1996;10(3):240-6.

7. Nesbit MJ, Hill M, Peterson N. A comprehensive pediatric bereavement program: the patterns of your life. Crit Care Nurs Q. 1997;20(2):48-62.

8. Althabe M. Consenso sobre recomendaciones acerca de la limitación del soporte vital en terapia intensiva. Arch Argent Pediatr. 1999;97(6):411-5.

9. Burns JP, Mitchell C, Outwater KM, Geller M, Griffith JL, Todres ID, et al. End-of-life care in the pediatric intensive care unit after the forgoing of lifesustaining treatment. Crit Care Med. 2000;28(8):3060-6.

10. McCallum DE, Byrne P, Bruera E. How children die in hospital. J Pain Symptom Manage. 2000;20(6):417-23. 
11. Meert KL, Thurston CS, Sarnaik AP. End-of-life decision-making and satisfaction with care: parental perspectives. Pediatr Crit Care Med. 2000;1(2):179-85.

12. Wolfe J, Grier HE, Klar N, Levin SB, Ellenbogen JM, Salem-Schatz S, et al. Symptoms and suffering at the end of life in children with cancer. $N$ Engl $J$ Med. 2000;342(5):326-33.

13. Carvalho PRA, Rocha TS, Santo AE, Lago P. Modos de morrer na UTI pediátrica de um hospital terciário. Rev Assoc Med Bras. 2001;47(4):325-31.

14. Hilden JM, Emanuel EJ, Fairclough DL, Link MP, Foley KM, Clarridge $\mathrm{BC}$, et al. Attitudes and practices among pediatric oncologists regarding endof-life care: results of the 1998 American Society of Clinical Oncology survey. J Clin Oncol. 2001;19(1):205-12.

15. Meert KL, Thurston CS, Thomas R. Parental coping and bereavement outcome after death of a child in the pediatric intensive care unit. Pediatr Crit Care Med. 2001;2(4):324-8.

16. Meyer EC, Burns JP, Griffith JL, Troug RD. Parental perspectives on endof-life in the pediatric intensive care unit. Crit Care Med. 2002;30(1):226-31.

17. Althabe M, Cardigni G, Vassallo JC, Allende D, Berrueta M, Codermatz $\mathrm{M}$, et al. Dying in the intensive care unit: collaborative multicenter study about forgoing life-sustaining treatment in Argentine pediatric intensive care units. Pediatr Crit Care Med. 2003;4(2):164-9.

18. Garros D. Uma "boa" morte em UTI pediátrica: é isso possível? J Pediatr (Rio J). 2003; 79(Supl2):S243-54.

19. Garros D, Rosychuck R, Cox P. Circumstances surrounding end-of-life in a pediatric intensive care unit. Pediatrics. 2003;112(5):e371-e9.

20. Andresen EM, Seecharan GA, Toce SS. Provider perceptions of child deaths. Arch Pediatr Adolesc Med. 2004;158(5):430-5.

21. Carter BS, Howenstein M, Gilmer MJ, Throop P, France D, Whitlock JA. Circumstances surrounding the deaths of hospitalized children: opportunities for pediatric palliative care. Pediatrics. 2004;114(3):e361-6. 
22. Torreão LA, Pereira CR, Troster E. Ethical aspects in the management of the terminally ill patient in the pediatric intensive care unit. Rev Hosp Clin Fac Med Univ São Paulo. 2004;59(1):3-9.

23. Zawistowski CA, DeVita MA. A descriptive study of children dying in the pediatric intensive care unit after withdrawal of life-sustaining treatment. Pediatr Crit Care Med. 2004;5(3):216-23.

24. Casanueva Mateos L, Ruiz LP, Sánchez DJI, Ramos Casado MV, Belda HS, Llorente de la Fuente A, et al. Cuidados al final de la vida en la unidad de cuidados intensivos pediátrica. Revisión de la bibliografía. An Pediatr (Barc). 2005;63(2):152-9.

25. Hinds PS, Schum L, Baker JN, Wolfe J. Key factors affecting dying children and their families. J Palliat Med. 2005;8(Suppl1):S70-8.

26. Kipper DJ, Piva JP, Garcia PC, Einloft PR, Bruno F, Lago P, et al. Evolution of the medical practices and modes of death on pediatric intensive care units in southern Brazil. Pediatr Crit Care Med. 2005;6(3):258-63.

27. Lago PM, Piva J, Kipper D, Garcia PC, Pretto C, Giongo M, et al. Limitação de suporte de vida em três unidades de terapia intensiva pediátrica do sul do Brasil. J Pediatr (Rio J). 2005;81(2):111-7.

28. Meert KL, Thurston CS, Briller SH. The spiritual needs of parents at the time of their child's death in the pediatric intensive care unit and during bereavement: a qualitative study. Pediatr Crit Care Med. 2005;6(4):420-7.

29. Rotta AT. Cuidados no final da vida em pediatria: muito mais que uma luta contra a entropia. J. Pediatr (Rio J). 2005;81(2):93-95.

30. Salas Arrambide MS, Poc OG, Miravete JLM, Pérez-Yarza EG, Caro IA. El pediatra ante la muerte del niño: integración de los cuidados paliativos en la unidad de cuidados intensivos pediátricos. An Pediatr (Barc). 2005;62(5):450-7.

31. Sharman M, Meert KL, Sarnaik AP. What influences parents' decisions to limit or withdraw life support? Pediatr Crit Care Med. 2005;6(5):513-8. 
32. Tonelli HA, Mota JA, Oliveira JS. Perfil das condutas médicas que antecedem ao óbito de crianças em um hospital terciário. J Pediatr (Rio J). 2005; 81(2):118-25.

33. Freyer DR, Kuperberg A, Sterken DJ, Pastyrnak SL, Hudson D, Richards T. Multidisciplinary care of the dying adolescent. Child Adolesc Psychiatr Clin N Am. 2006;15(3):693-715.

34. Matthews K, Gambles M, Ellershaw JE, Brook L, Williams M, Hodgson A, et al. Developing the Liverpool Care Pathway for the dying child. Paediatr Nurs. 2006;18(1):18-21.

35. Robinson MR, Thiel MM, Backus MM, Meyer EC. Matters of spirituality at the end of life in the pediatric intensive care unit. Pediatrics. 2006;118(3):e719-29.

36. Tibballs $\mathrm{J}$. The legal basis for ethical withholding and withdrawing of lifesustaining medical treatment in children. $J$ Law Med. 2006;14(2):244-61.

37. Woodgate RL. Living in a world without closure: reality for parents who have experienced the death of a child. J Palliat Care. 2006;22(2):75-82.

38. Duncan J, Spengler E, Wolfe J. Providing pediatric palliative care: PACT in action. MCN Am J Matern Child Nurs. 2007;32(5):279-87.

39. Lago PM, Devictor D, Piva JP, Bergounioux J. End-of-life care in children: the Brazilian and the international perspectives. J Pediatr (Rio J). 2007;83(2 Suppl):S109-16.

40. Lago PM, Garros D, Piva JP. erminalidade e condutas de final de vida em unidades de terapia intensiva pediátrica. Rev Bras Ter Intensiva. 2007;19(3):359-363.

41. Longden JV, Mayer AP. Family involvement in end-of-life care in a paediatric intensive care unit. Nurs Crit Care. 2007;12(4):181-7.

42. Martino Alba R, Casado Flores J, Ruiz Díaz MA. Actitudes y necesidades de los intensivistas pediátricos ante la muerte de sus pacientes. An Pediatr (Barc). 2007;66(4):351-6. 
43. Meert KL, Eggly S, Pollack M, Anand KJ, Zimmerman J, Carcillo J, et al. Parents' perspectives regarding a physician-parent conference after their child's death in the pediatric intensive care unit. J Pediatr. 2007;151(1):50-5, 55.e1-2.

44. Ramnarayan P, Craig F, Petros A, Pierce C. Characteristics of deaths occurring in hospitalised children: changing trends. J Med Ethics. 2007; 33(5):255-60.

45. Hendrickson K, McCorkle R. A dimensional analysis of the concept: good death of a child with cancer. J Pediatr Oncol Nurs. 2008.

46. Inwald D. The best interests test at the end of life on PICU: a plea for a family centred approach. Arch Dis Child. 2008;93(3):248-50.

47. Tagarro García A, Dorao Martínez-Romillo P, Moraleda S, López P, Moreno T, San-José B, et al. Cuidados al final de la vida en una unidad de cuidados intensivos pediátricos: evaluación por parte del personal y de los padres. An Pediatr (Barc). 2008;68(4):346-52.

48. Welch SB. Can the death of a child be good? J Pediatr Nurs. 2008;23(2):120-5.

49. Wolfe J, Hammel JF, Edwards KE, Duncan J, Comeau M, Breyer J, et al. Easing of suffering in children with cancer at the end of life: is care changing? J Clin Oncol. 2008;26(10):1717-23. 
10 ANEXO

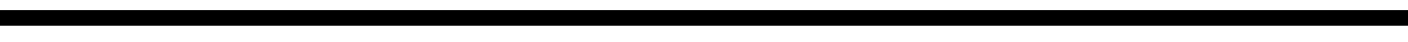




\section{ANEXO 1}

\section{TERMO DE CONSENTIMENTO LIVRE E ESCLARECIDO PARA PARTICIPAÇÃO NA PESQUISA CIENTÍFICA}

\section{Projeto: $\mathrm{O}$ desenvolvimento do conceito de morte digna na UTI pediátrica}

Meu nome é Kátia Poles (pesquisadora responsável, COREN-MG 86197), doutoranda pela Escola de Enfermagem da Universidade de São Paulo, sob orientação da Profa. Dra. Regina Szylit Bousso. Estou realizando um estudo que pretende desenvolver o conceito de morte digna na UTI pediátrica. Para tanto, estou entrevistando enfermeiras e médicos que aceitem voluntariamente contar-me a respeito de sua experiência no cuidado de crianças em final de vida na UTIp, com a finalidade de oferecer subsídios para o cuidado nessa situação.

A entrevista será realizada em local privado e seu conteúdo será gravado para posterior transcrição e análise dos dados. As fitas das entrevistas permanecerão guardadas com a pesquisadora e somente ela e sua orientadora terão acesso a seu conteúdo.

São garantidos o sigilo das informações, o anonimato dos participantes, bem como a possibilidade de deixar de participar deste estudo a qualquer momento, mesmo após ter assinado o termo, ou seja, você poderá retirar seu consentimento, em qualquer fase da pesquisa, sem penalização alguma ou prejuízo à sua prática profissional.

Se, após a concessão da entrevista, em algum momento, desejar que os dados não devam mais ser utilizados, você poderá contatar a pesquisadora, com a certeza da devolução da fita gravada, bem como destruição da transcrição.

Em qualquer etapa do estudo, você terá acesso à pesquisadora responsável para esclarecimento de eventuais dúvidas no telefone (11) 3061-7601 ou no seguinte endereço: Av. Dr. Enéas de Carvalho Aguiar, 419 - 05403-000 - São Paulo - SP. E-mail: kpoles@usp.br

Os resultados obtidos serão divulgados em eventos e publicações científicas.

Este documento possui duas vias, uma ficará em posse da entrevistada e a outra arquivada com a pesquisadora, Kátia Poles.

Acredito ter sido suficientemente informado(a) a respeito das informações que li, descrevendo o estudo "O desenvolvimento do conceito de morte digna na UTI pediátrica". Discuti com a pesquisadora Kátia Poles sobre a minha decisão em participar nesse estudo. Ficaram claros para mim quais são os propósitos do estudo, os procedimentos a serem realizados, seus desconfortos e riscos, as garantias de confidencialidade e de esclarecimentos permanentes. Concordo voluntariamente em participar deste estudo e poderei retirar o meu consentimento a qualquer momento, antes ou durante o mesmo, sem penalidades ou prejuízo para minha prática profissional.

São Paulo, de de 200 